QH

197
M58

1889

Bot.

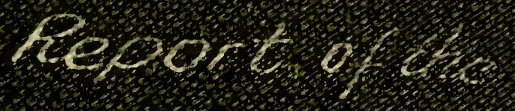

Govenomeds

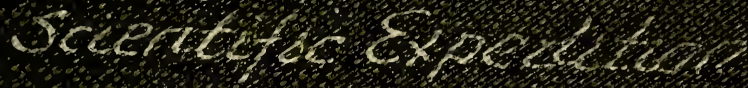

6.

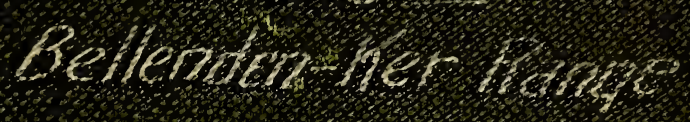

18000 

$w 13$

Naluable, original description of

Citrus inodorus us $3 \%$. page 34.

by F.M. Bailey, Colonial botatist prehiled late in/839 cafter 7 cect $1889 \%$. 



DEPARTMENT OF AGRICULTURE.

1889 Bot-

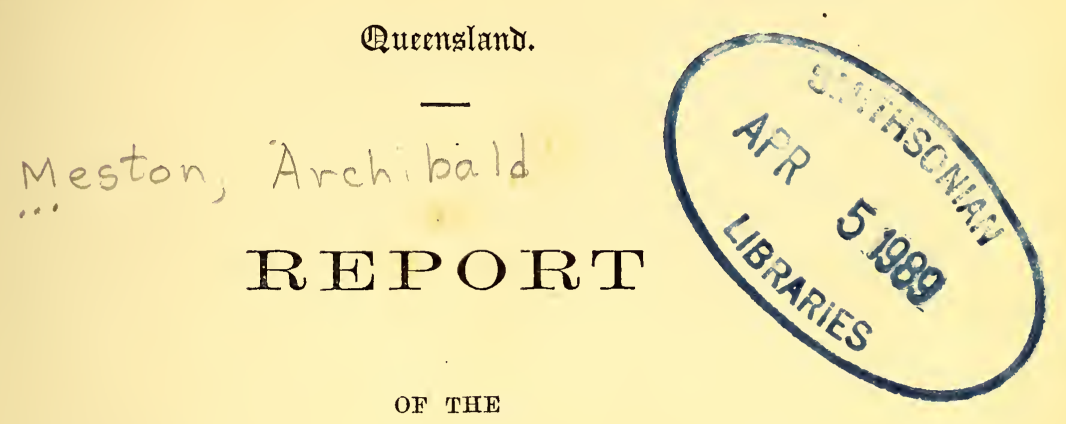

GOVERNMENT SCIENTIFIC EXPEDITION

To

\title{
BELLENDEN-KER RANGE
}

\author{
UPON THE
}

FLORA AND FAUNA OF THAT PART OF THE COLONY.

\section{BRISBANE :}

BY AUTIORITY : JAMES C. BEAL, GOVERNMENT PRINTER, WILLIAM STREET. 

Publications.-Bulletin.-During the year the Department has published and distributed a great number of pamphlets and leaflets, amongst which may be mentioned the report of the Agricultural Conference, Insect and Fungus pests by H. Tryon, and the Scientific Expedition to the Bellenden-Ker Ranges. Judging from the eagerness exhibited to secure these reports and pamphlets, and the interest shown therein, I would submit that the time has. now arrived when the Department might issue a quarterly bulletin containing matters of interest to agriculturists. There are constantly being developed new phases of agriculture in which those engaged therein should be kept well posted, so as to be able to successfully compete in the open market with those already in possession of new conditions. A course of instruction such as these bulletins would scatter abroad, would entail a cost of a small sum annually for publication and of labour in preparation, but the results therefrom would, I believe, be of the highest value in the development of the agriculture of the colony. 
Governament Domain Reserve.-A small vote of $£ 50$ was placed upon the Estimates for 1889-90 for clearing this reserve of lantana. This is now being effected, and had the wet season this year not been so prolonged would have been accomplished before now.

Previously to this reserve being handed over to this Department, it would appear that the residents of the neighbourhood looked upon it as a paddock provided by the Government for the use of their horses and cattie. These have all been cleared out, and the reserve is under the care of a member of the Defence Force, who only have permission to agist their horses therein.

Botanic Gardens, Brisbane.-A report by the Curator of the year's operations and the state of the gardens is appended. The late incessant rain has clearly demonstrated the utter uselessness of the present house as a place of residence for the Curator. Mr. MacMahon had only resided in the house a few weeks from the time that it was repaired, when he had to be earried out, suffering from a severe fever 
by surveyors and local residents. This would serve the double purpose of establishing an appropriate and pleasing geographical nomenclature, and perpetuating at least one of the most interesting parts of native dialects, otherwise doomed to deplorably early annihilation. The native name of Bartle Frere is "Chooreechillum"; that of Bellenden-Ker is "Wooroonooran," pronounced slowly with equal accent on all four syllables. The name Bellenden-Ker was bestowed in 1803 by Captain Flinders, after T. Bellenden-Ker, a botanist of the period.

On the east side of Tringilburra Creek, the north spur of the Bellenden-Ker Range terminates on the edge of the Mulgrave Plain. That spur rises gradually to Mount Toressa, the first peak, at a height of 2,600 feet. This is an abrupt sharp-pointed mountain falling suddenly from the crest on south and west in precipices 300 or 400 feet in depth. From the summit you look down on the Mulgrave Valley and the mouth of the Russell, with a clear view away to the north and west. Descending from Toressa about 600 feet, and following the crest of the connecting ridye, you come to the ascent of Mount Sophia, which rises suddenly to a height of 4,100 feet. This is also a sharp-crested peak covered by dense rank vegetation. Descending 1,000 feet from the summit of Sophia you cross the intervening saddle which separates it from the north peak of Bellenden-Ker, rising by an unpleasantly steep ascent to 5,000 feet.

To this peak from the starting point on the Mulgrave Plains the range is running south-south-east. From the north peak to the centre peak the direction is nearly due south, and thence to the south end the mountain curves gradually to south-south-west. The north peak has a huge spur running down into broken ranges terminating in the junction of the Mulgrave and Russell, the gorge at the foot of the spur being drained by a branch of Harvey's Creek. The total length of the Bellenden-Ker Range, from the Mulgrave Plains to the south end, which at a height of 5,000 feet stands facing Bartle Frere, is about twenty or twenty-five miles. From end to end the whole range is covered on both sides by dense tropical jungle, that on the eastern or Russell River side being the most luxuriant. There is not a bare foot of ground on the whole extent of summit or the radiating spurs. Once on the north peak, at 5,000 feet, you are actually on the top of Bellenden-Ker, though the centre peak rises 200 feet higher. The view is magnificent beyond all possible description, and only bounded by the sky line on the edge of the horizon. Further physical features will be given in another part of the report.

On the 16th June Senior-Constable Whelan came over from his camp on the Mulgrave with troopers and pack-horses, in accordance with instructions kindly wired by Mr. Commissioner Seymour, who requested him to afford the expedition all reasonable assistance. It is my duty to mention here that the police assistance was of special value to the party, and saved a considerable anount of expense. Senior-Constable Whelan did all in his power, within whatever time was not actually necessary for the discharge of his own official duties, and he is certainly entitled to grateful mention in this report. On the night of the 16 th we camped at the head of the valley of Tringilburra Creek, beside the junction where one branch comes down from under Sophia and Toressa, and the other from Bartle Frere and the west side of Bellenden-Ker. 
On the morning of the 17th we prepared for the start towards the mountain. We had reached the last point accessible by horses, and thenceforth all the journey had to be done on foot. We struck camp and crossed the creek at 8 o'clock in the morning, leaving one blackboy in charge of a tent which formed the base of supplies. On crossing the creek, a clear, strong stream running rapidly over and between large granite boulders, we began at once the ascent of Barnard's Spur, a long, narrow forest ridge, rising to a height of 1,700 feet. The timber along this spur is chiefly bloodwood, Moreton Bay ash, and the casuarina usually known as forest oak. Only the crest of the spur is bare, and the sides for a hundred feet, the forest ending suddenly in dense dark scrub. On the right you look down on the main creek between Barnard's Spur and the main range, and on the left into the branch which drains the western slopes of Sophia. There are outcrops of quartz on several parts of the spur, but none showing the faintest traces of gold. At 12 o'clock we reached the summit at 1,700 feet, the site of an old blacks' camp, several of the structures still standing-large dome-shaped camps made from bent saplings, with grass roofs. From this point we could see the whole of the BellendenKer peaks, the summit of Bartle Frere, and Cairns, and all the Inlet country away to the north.

Here was the last of the forest, there not being an acre of open country for all the rest of the journey to the top of the mountain. The temperature in the shade at midday was 78 degrees.

We descended 700 feet along a small old blacks' track leading down a very steep descent into the junction of two creeks. Here is the point where Tringilburra Creek divides-one branch going eastward draining the whole western face of Bellenden-Ker, and the other bringing down the water from the north slopes of Bartle Frere, the west end of Bellenden-Ker, and the east side of the main range. The spur which ends in the junction runs right to the summit of the south peak of Bellenden-Ker, and was the route chosen for the ascent. All between this spur and one connecting Barnard's Spur with Mount Sophia is a vast concave basin, into which all the slopes and ridges of the mountain, from the north to the south peaks, converge in dark gloomy ravines covered by dense tropical vegetation. We camped on the 16th at the junction named, on a previous occasion, the "Whelanian Pools." Here the two creeks unite and pour their combined waters away to the north, down a long narrow gorge flanked by mountains descending sheer down on each side, the beautiful trees at the base hanging over the current in perpetual shade.

We pitched our camps on the bare granite rocks, swept clean by the tremendous torrents that rushed down those two gorges for nameless centuries of tropic rains. The temperature at night was 56 degrees; the water in both creeks 58 degrees. Elevation, 1,000 feet.

On the 18th all hands were out collecting in all directions.

About half-a-mile down the main creek is one of the loveliest scenes in Australia. From the main range on the west side there comes a large impetuous torrent which forms a series of eight magnificent cascades from 50 to 100 feet in height, one above the other, falling in sheets of snow-white foam, forming a nearly unbroken line of water to a height of 500 feet, the last cascade visible in the far end of the dim vista terminating in the dark ravines away far overhead on the face of 
the mountain. Dense jungle and heavy foliaged trees hang over the torrent. Ascending the sidewalls to the crest of the first fall, you stand facing a deep black pool between two pillars of smooth-faced perpendicular rocks. This pool receives the second fall, and beyond that rise the others in one silver-flashing sublime staircase of descending waters.

Mr. Bailey went down with me to behold this scene, and supplied the following notes on the vegetation :- "Overhanging the lower fall is the umbrella-tree (Brassaia actinophylla) and the pine-tree (Callitris Parlatorei). Above the water near the next fall is a large specimen of a Northern water gum (Tristania exiliflora), the trunk covered by a dense mass of climbers and epiphytes, conspicuous among them being the lovely little fern Davallia pedata, Hoya australis, Hoya Nicholsonia, Dioscorea transversa, and Lygodium reticulatum. There are numerous epiphytes and a fine specimen of the ribbon fern (Ophioglossum pendulum) hanging from a horizontal branch, besides Dendrobium speciosum fusiforme, Dendrobium hispidum, and Bulbophyllum nematopodum. In the crevices of the rocks are tufts of Pogonatherum saccharoideum, an Indian grass only lately known to inhabit Queensland, and on the perpendicular walls some splendid masses of Bulbophyllum Baileyi with unusually large leaves."

The scene at this spot in the wet season must baffle the human imagination. Even in the dry weather it was a picture of fascinating loveliness, the future paradise of the artist and the lovers of the beautiful, the scenery-hunting tourists of years to come, when the lower ravines of the Bellenden-Ker are become familiar to the outside world of amateur explorers.

To this series of splendid cascades I have given the name of the "Morehead Cataracts," a deserved eompliment to the Chief Secretary and Premier of a Government possessing the honourable distinction of being the first to send out in any part of Australia a purely scientific expedition. Below these, on the main creek, are the "Francesca Falls."

On the 19th Whelan and myself started up the mountain in the morning and cut a track through thick scrub up to 2,600 feet. At a height of 2,300 feet we again found the remarkable fruit which $\mathrm{Mr}$. Bailey has named Garcinia Mestoni, or "Meston's Mangosteen," seeds of which I brought down from my first visit to the mountain and gave to Mr. Soutter, of the Acclimatisation Gardens. On this occasion we found it the size of a small apple, apparently not half grown, as the one discovered last trip was as big as the largest orange. It never changes colour, being a bright olive green, whether half grown or fully ripe. It is the first of the Garcinia family ever found in Australia, and promises to be a specially valuable addition to the fruits of the world. The taste, when ripe, is an exceedingly agreeable acid, and even the half-grown fruit can be eaten with a sense of considerable satisfaction on a hot day; Whelan and myself found it wonderfully refreshing.

On the 20th, Thursday, Mr. Bailey, Whelan, Harold, and myself started the ascent of the inountain, leaving all the blackboys with $\mathrm{Mr}$. Broadbent at the Pools, the second base of supplies, the whole of them to follow us next day, except one boy left in charge of the camp. The ascent is through thick scrub the whole way to the summit, there being unly one small open patch, covered by ferns, at 2,700 feet. 
From 2,600 feet we had to resume our track-cutting, no very light work for Whelan and myself when carrying forty-pound swags, and having not only to clear a track for the loaded boys next day but to find out the proper route to follow. Towards evening we arrived at the first water, at 4,050 feet, or 3,050 feet above our starting point in the morning, Mr. Bailey not only enduring the journey without serious fatigue, but making careful observations on the flora as he went along, the necessarily slow pace we travelled enabling him to do this at comparative leisure. The point we stopped at is known as the "Palm Camp," from a superb palm, beneath the spreading top of which we made our fire and slept. About 200 feet down on the west side, and not more than 300 yards from the palm tree, is a small running stream of pure clear ice-cold water, completely shaded by the tall scrub and beautiful tree ferns. The crest of the spur is not more than 50 yards wide, and falls off abruptly on each side into the depths below. There are many very tall trees and some of considerable size, especially Kauri pines, which attain gigantic dimensions. The lawyer vine and stingingtree are left behind at about 2,000 feet, but all the way up is a thick wiry undergrowth, which places track-cutting outside the pale of amusement. The south peak of Bellenden-Ker was still 1,000 feet above us, through six miles of heavy scrub with no track cut.

On Friday, the 21st, Broadbent arrived with five boys loaded with provisions and camp utensils. The temperature at night was 54 degrees, at mid-day 62 degrees, and the water 54 degrees.

While Mr. Bailey was collecting round the camp, Whelan and myself cut a track on to the second water, a stream similar to the first, about two miles further on.

On Saturday, the 22nd, ..the whole party started for the summit and arrived on the south peak about 2 o'clock. The vegetation here is one tangled solid mass, impenetrable without the cane-knife. All hands were busy with knives and tomahawks for about three hours to clear enough space to camp on. All around and below us were clourls and mist, the clouds breaking on the summit of the mountain and discharging a light drizzling rain. The camp for the night was only temporary, and as heavy rain fell and ran under the oil-cloth and we were all lying with some part in the water, and the thermometer at 48 degrees, with an ice-cold wind blowing, it is natural to report that nobody slept very much that night, and no one had any desire to repeat the experience. My chief anxiety was for Mr. Bailey, who, however, bore the unpleasant ordeal and all other unpleasant priva. tions during the trip with a cheerful fortitude highly creditable to a man of his age, and very gratifying to myself. Mr. Broadbent was also a hardworking, contented companion.

Sunday, the 23rd, was a wet, cold, miserable day, the thermometer at noon only 56 degrees, with a westerly wind, bleak and chilly enough to make the blackboys crouch shivering round the fire. Whelan and myself started out to cut a track to the centre peak, about two miles off, through indescribable vegetation, the worst of which is a drachophyllum tree, bearing a splendid flower, with long, tough, gnarled, wiry branches all tangled together. None of the other peaks could be seen, nor was Bartle Frere visible across the intervening abyss, dense white clouds hiding all things beneath an impenetrable veil. We could only guess at the exact position of the centre peak. The whole south end of Bellenden-Ker from the centre peak broadens out to 
about three-quarters of a mile in width by two miles across from the peak to the outer edge opposite Bartle Frere. This area consists of low short spurs running in all directions covered by thick vegetation and loose granite rocks, intersected by watercourses with beds of clean granite gravel. The trees are nearly all short and gnarled, and all, without exception, hard as bone. Many of them when cut prove to be highly and pleasantly odoriferous. Conspicuous among the vegetation is a dome-topped tree with foliage so thick that not a ray of sunlight penetrates, and the outer top is so perfectly level that two men viewing each other from the summit of two of these trees appear exactly as if they had protruded their heads from the domes of two green pavilions, only the heads visible. One beholds a strange and beautiful sight by ascending a tree and looking over the tops of the others, which appear like a lovely leading colour in the tesseraic floor of various shades of green covering the mountain away towards and over the centre peak. After cutting through for half-a-mile we returned to the camp.

On the 24th Whelan started down the mountain, taking five boys and leaving one with us. A trooper had come with a note to say he was required on the head of the Russell, on account of some murders by the blacks. This was another cold day with drizzling rain. Sent the blackboy to cut a track towards the south for $\mathrm{Mr}$. Broadbent to shoot over, and went away alone to continue the track to the centre peak. Every stroke with the knife brought down a shower of water from every shrub, as an addition to the light drizzling rain. The temperature was 54 degrees, with the usual wind sweeping through the trees, chilling the very bones. Cut within half-a-mile of the centre peak, and returned about 4 o'clock. Mr. Bailey and Mr. Broadbent had done their best collecting all day under very disheartening conditions, and Harold, too, went out daily in defiance of wind and rain.

On Tuesday, the 25th, Broadbent accompanied me to the centre peak, which we reached about midday, and stood at last on the highest point of Bellenden-Ker, at 5,240 feet; the first men, beyond all question, who ever put a foot on what will be shown in this report to be the highest land in Queensland. The centre peak runs out to the eastward to a sharp steep razor-back point, not fifteen yards wide, falling straight off on both sides. A clear and unobstructed view is obtained in all directions on a clear day, but on this occasion we lonked down on nothing but a waste ocean of white cloud, about 300 feet below, stretching away in all directions to the horizon, all the surface rippled into motionless waves and unsullied by a single speck, save the extreme peak of Bartle. Frere, like a small black rock rising from a limitless milk-white sea. In the evening, when returning, the air was cold and clear, with a bitterly sharp wind blowing. The temperature fell at sunset to 48 degrees. 'T'hree of the boys had arrived during the afternoon with provisions. At night the thermometer fell to 30 degrees, or 2 degrees of frost. This was the severest cold during the trip, and we felt it acutely, being unable to keep sufficiently warm at night to sleep. The boys took special care to keep a continuous fire.

Wednesday, the 26th, was the first fine day on the summit, and the coldest, being only 40 degrees at noon, with the usual wind. After breakfast I started once more for the centre peak, taking Harold 
and the blackboy "Multarri." On arrival at the lookout point there was not a speck in the heavens within the circle of the horizon-only a pathless wilderness of immeasurablo azure in which all objects were marvellously distinct. To the south the summit of Mount Eilliott was clearly visible, a distance of at least 140 miles. The Cardwell and Hinchinbrook ranges were as plain as if only twenty miles away, and to the west the view extended an incredible distance to far-off mountains of fantastic shapes, blue and shadowy on the edge of the remote sky-line. There was a magnificent view of all the Upper Barron and Herberton country, and the tablelands on the heads of the Johnstone, Moresby, Tully, and Herbert rivers.

One glance conveyed more knowledge of that vast expanse of nearly uninhabited country than could possibly be obtained by many months of weary "exploration. The crest of "Peter Bott" stood outlined beyond the Port Douglas ranges, and north-west mountains rose beyond mountains as far as the eye could see. Below me was the valley of the Russell, with the sinuous river winding through the rich expanse of tropical scrub land. Behind Point Cooper were the extensive, treacherous, swampy plains that extend from the Russell nearly across to the Johnstone. All the plantations and sugar-mills on the Johnstone were plain enough at a distance of about thirty-five miles. The blasting on the second section of the Cairns Railway was just as distinctly heard as if it were only ten miles away. Below me on the eastward, between the centre peak and the Russell, was a mountain, about which there appears to be a surprising amount of ignorance even among the oldest local residents. It stands detached from Bellenden-Ker, connected, however, at the base by a spur which divides the waters of Harvey's Creek from those flowing towards Babinda Creek. It is a sharp-pointed razor-backed mountain, rising somewhat abruptly in successive peaks from the eastward, and falling off suddenly on the north and south in steep spurs, covered by exceptionally dense vegetation. This mountain seemed to be about 1,200 feet lower than the peak of Bellenden-Ker, and I made a note to that effect. My surprise was considerable to find, on returning from Cairns by the "Waroonga," that this unnamed mountain was marked on Captain Border's chart, and the height given at a trifle under 4,000 feet, so that my guess at the elevation was remarkably correct. This mountain will again be specially referred to in the report. The whole of the eastern side of Bellenden-Ker, from the south end to the north peak, is practically inaccessible-that is, a qualified man could doubtless make the ascent at some point, but he could carry nothing but himself, and no one but a madman would try it. The whole face of the mountain is a sheer descent into the gorge below, drained by Harvey's Creek. The whole corresponding western face falls just as sheer down into the branch of Tringilburra Creek, and is equally inaccessible. The Bellenden-Ker Range can be ascended at both ends and nowhere else, except as a mere foolish and useless feat of climbing, just as a man might go to the top of a lighthouse by an outside rope, instead of ascending the staircase. From the centre peak we descended about 200 feet on to the crest of the mountain to the north, and had to lower ourselves down by vines and shrubs that held on by twisting their roots among the rocks. Proceeding thence along the summit at an arerage height of 4,900 feet, cutting a track chiefly through the Dracophyllum and a rank growth of the beautiful 
tree-ferns Alsophila Robertsoniana and A. Rebecca, we arrived at another peak rising 5,100 fcet; and decided to return in time to arrive at the camp with daylight. From the centre peak to the point of return the crest of the mountain is not 12 feet wide, and falls on each side sheer down into apparently unfathomable gulfs, and yet all these steep slopes are covered by luxuriant and beautiful trees and shrubs and splendid ferns. The day was intensely cold, and "Multarri's" teeth were chattering as he walked behind me. Harold also regarded the temperature with grave dissatisfaction. We arrived in camp before sunset, and found a note from Whelan to say he would not be able to return for at least two weeks. Decided to descend next day to the 4,000 feet level. Mr. Bailey thought we had collected all, or nearly all, of the plants flowering or fruiting at that time of year, and there were not many specimens obtainable by Mr. Broadbent, as the birds had left the cold bleak summits and gone down into the warm gorges and ravines. The tracks of the tree-climbing kangaroo, called "Mappee" by the blacks, were plentiful, and yet we never saw one, and would have some difficulty in finding them without a dog in such vegetation as covers the south end of the mountain. The summer is the time for the ornithologist to collect on the summit, and he could also shoot enough birds to supply himself with food, as the pheasant-tailed and white-headed pigeons go there in great numbers to breed. In winter not only is there but little bird life, but the severe cold makes existence extremely uncomfortable.

On Thursday, the 27 th, we all said good-bye to the south peak without a pang, and started for lower and warmer latitudes. Arriving at the Palm Camp, at 4,000 feet, we left Messrs. Bailey and Broadbent there with two boys and five days' provisions, and Harold and myself and three boys went on to the Whelanian Pools, arriving there in the evening.

On the 28th left one boy in charge of part of the camp, and took the remainder to the lower camp, where Beman was in charge. Sent the two troopers back at once to Whelan, on the Mulgrave. Temperature at night, 51 degrees; water, 58 degrees; shade at noon, 73 degrees.

On the 29th sent boys back for the balance of the Pools camp, and then ascended 2,000 feet on a mountain to the westward, and obtained some specimens for Mr. Bailey. We know this mountain as "Mount Harold." Among the savage precipices on the summit I tried in vain to obtain a specimen of what seemed to me a new species of rock wallaby, an animal that possesses a miraculous capacity to vanish on the shortest notice down the face of precipices or along the edge of cliffs.

On Sunday, the 30th, sent Beman and a boy to the Pools for articles still remaining there, left Harold in charge of camp, and went up the creek towards Mount Sophia on a geological tour. The watercourses are crossed in many places by very likely looking reefs, but no signs of gold, though here and there are traces of tin. All the creeks on the west side of Bellenden-Ker are too precipitous to hold any loose minerals, and it is very doubtful indeed if any exist there, except in worthless quantities. The spurs of Mount Harold appear to be composed chiefly of quartz reefs which "blow" all over the surface. The formation nearly everywhere shows granite, quartz and slate, a promising combination certainly, and perhaps worthy of attention from stray prospectors. It is entirely unknown country. 
On Monday, 1st July, sent Beman and "Jimmy" to the Palm Camp, to bring down Messrs. Bailey and Broadbent.

On the 2nd Harold and myself went down the east side of the main creek, crossed over to Mount Harold, and went to the top a second time, with the same results so far as the wallabies were concerned, though we saw a score of them at a safe distance: dark red wallabies with long tufted tails.

On the 3rd Bailey, Broadbent, and party arrived, having camped the previous night on the crest of Barnard's Spur. At night the thermometer fell to 42 degrees.

On the 4th Bailey and myself went out collecting, and displayed an amicable unanimity by falling into a creek together, and a great deal of self-possession and agility in getting out again.

On the 5th Broadbent, Harold, myself, and two of the boys made a third ascent to the summit of Mount Harold, and again failed to sccure a wallaby, though we obtained a few other specimens. On the way up I killed a carpet snake containing some animal undergoing a process of digestion. On my return one of the boys brought it down, and we found the animal to $b^{\circ}$ a fair-sized common wallaby. How so small a snake swallowed so large a beast is a problem no one but the snake could possibly explain.

On the 6th the whole party were out collecting in various directions. On the 7 th, Whelan came over from the Mulgrave, and we decided that he and I should make a flying trip round the whole Bellenden-Ker Range from south to north. On the 8th, we started with three boys, who were to meet us on the summit of Barnard's Spur after we had followed up and explored the main creek. At night we camped in a blacks' camp on the spur mentioned, heavy rain falling and dripping through the roof and down our backs all night, so that sleep had to be postponed for another occasion.

In the morning the creek at the Pools was uncrossable, so we returned to the camp to find the main creek flooded. We were compelled to strip and swim across through the least dangerous channels among the granite rocks.

On this date the Government prospecting party, in charge of James Toohey, came up and camped on the creek beside us. While Broadbent was out to-day he found the skeleton of a black-fellow, and brought in the skull for the Museum.

On the 10th Whelan took the prospectors to see some reefs near Mount Sophia, Bailey and Broadbent went up the creek, and "Multarri" and myself partly ascended Mount Toressa.

On the 11th we shifted camp to the edge of the Mulgrave Plain, on Tringilburra Creek, and remained six days, making a considerable collection of plants, birds, and land sheils. Game was plentiful here; turkeys, pigeons, and scrub hens more than sufficient to supply the camp. One of the blackboys was discharged on the $17 \mathrm{th}$, and "Multarri" sent back with grateful thanks to Swallow and Derham. On the 1Sth Bailey, Broadbent, Harold, myself, and the two boys went down to the Russell River, leaving the camp in charge of Beman.

At the Russell we were again joined by Whelan, and he and myself started for Bartle Frere on Saturday, the 20th of July. We rode eighteen miles up the river, the track all the way through some of the densest brush in Queersland, and stayed all night at "I'eechappa," an old bora ground, used as a camp for the lower alluvial diggings on 
the Russell, now nearly deserted. In the morning we went on twelve miles to a bora ground called "Choonbine," where we met our two boys who had gone there the day before to meet a native black, who was to accompany us to the summit of Bartle Frere.

Finding all three there, we started up the mountain about 2 o' clock. The ascent, as usual, was through thick scrub, and after ascending a few hundred feet we came on old marks made by Christie Palmerston and a band of eight myalls who had gone up there in October, 1886. We camped that night on a narrow ridge 2,000 feet high, a runniug creek a couple of hundred feet down to the westward.

On Monday, the 22nd, we resumed the ascent, passing through thick heavy timber and enormous granite rocks. At 3,000 feet we came on one of Palmerston's camps on the edge of a landslip that formed a precipice on the east side of the spur.

At 4,000 feet we found a small stream of delightfully cool pure water, and made some tea and ate a few sandwiches under a cold drizzling rain. We arrived on the summit about 3 o'clock, and found the trees marked by Palmerston, and Mr. Jack, the geologist, on the 9th of February, 1888, and October 26th, 1886. The aneroid made the highest point exactly 5,000 feet, the same height as the south end of Beilenden-Ker, and 200 feet lower than the centre peak. There is no doubt whatever in my mind that Bellenden-Ker is at least 150 feet higher than Bartle Frere, allowing for all the barometric variations. Strange to say, though these two mountains stand facing each other, divided only by a deep valley drained by a few granite creeks, the vegetation of one is entirely different from that of the other. There is no trace on Bartle Frere of the dome-shaped tree and the Dracophyllum which cover the whole south end of Bellenden-Ker. All the crest of Bartle Frere is covered by confused masses of granite rocks, some of the isolated boulders 20 to 50 feet high. There are bare patches covered only by loose stones and stunted shrubs a couple of feet in length. The whole summit is a wild, savage, inhospitablelooking region, fit to be regarded as that dismal spot "Where the Old Earthquake Demon nursed her young Ruin." And yet there are beautiful flowering trees and lorely orchids and rare and splendid plants growing among those thunder-scarred and merciless rocks. Some specimens we collected that evening, and others were obtained next day. We camped all night on the highest point beside a granite rock. After a couple of hours collecting in the morning we started to descend. We saw nothing from the summit but driving masses of clouds above, below, and around us. Once only through a "winddivided chasm of wandering mist" we saw, for a few seconds, the dark peaks of Bellenden-Ker, and the closing clouds shut them out for ever. There was a weird fascination, too, on that lone peak among the warring clouds, the spectral mists, the black pitiless rocks, and the moaning of desolate winds, but poetry was not the study of the moment, and we tore ourselves away without a pang.

After descending 2,000 feet, the myall-by special requestturned down another spur as a short eut, avoiding the route round by Choonbine. It certainly did cut off a few miles, but as we went down one place, about 1,400 feet in apparently not more than half-a-mile, Yabba's short cut is not likely to become popular as a direct route to or from the top of Bartle Frere. After emerging on the track to the 
Upper Russell diggings we walked seven miles over very rough hilly road, and arrived at Teechappa about 6 o'clock, a solid rapid walk from the summit of about eight hours in cold misty rain.

On the 24th we returned to Harvey's Creek at the mouth of the Russell, the journey down being in torrents of rain from start to finish. Raining all day on the 25th. Took one of the boys and went across the river and up the coast range. The weather not being propitious, we all returned on the 26th to the camp on the Mulgrave. In the evening Harold shot a very fine cassowary weighing $186 \mathrm{lb}$., the liver weighing $4 \mathrm{lb}$., and the heart as large as a sheep's. This bird is now set up in the Museum.

On the 29th we shifted camp over to the Mulgrave, where we received all possible consideration from Senior-Constable Whelan. The next four days were employed in collecting in the vicinity of the Police Camp. On Friday, the 2nd of À agust, I went alone up the Walsh. Pyramid ("Charroogin"), and brought specimens for $\mathbf{M r}$. Bailey from the summit at 3,050 feet.

On Sunday, the 4th, I took Harold and three blackboys and started to explore the ranges at the head of the Little Mulgrave. That night we camped at Jensen's, on the Herberton road. In the morning we started up the valley of Wright's Creek, crossing at the start a small detached hill 650 feet high.

Following up the valley through thick scrub we arrived at the head of the creek, and camped on a small bare hill 600 feet high. Next morning, the 6 th, we started up the range on a spur so steep that we had to crawl at times on our hands and knees. In at least two places a false step meant certain destruction; but we had to go up or go back, and I have the same contempt as Mirabeau for "that blockhead of a word "impossible." " One of the boys, a Mulgrave native named Toby, out on his first journey with me, knocked up, and I had to take most of his swag. We camped that night on the crest of the range at 2,450 feet. .Temperature at night, 56 degrees; shade at noon, 74 degrees. Next day, the 7th, we started along the top of the range through thick scrub and splendid hardwood timber, some of the trees six and seven feet in diameter. At noon we were on the head of the Little Mulgrave and. Freshwater Creek, on a mountain 3,000 feet high, commanding a complete view of a vast expanse of country. It may be well to mention here that when Christie Palinerston was across that country about three years ago, looking for a railway track at the request of the Government, he reported the discovery of 30,000 acres of grand country on the head of Freshwater Creek, and induced the Minister for Lands to reserve that area. It is my duty to report here that these 30,000 acres of grand country exist nowhere outside of Palmerston's imagination. The heads of Freshwater Creek, the Clohesy, and Little Mulgrave rise in rough broken ranges and deep rocky gorges, and there is not 100 acres of level or available country on one of them. During the day the first nest and egg of "Meston's Bower Bird"-Prionodura Newtonianawas found by me in the fork of a small tree about seven feet from the ground. The female flew off the nest, and the male was sitting on an adjoining tree.

Near here was found the complete skeleton of a wallaby at 3,000 feet, and I brought it down for the Museum. How a wallaby ever got into such a place is a mystery to me, as no wallaby ever lives on 
the crest of such a range as that. He would certainly starve to death. Passed piles of huge rocks covered by ferns and flowering orchids, and through groves of magnificent palms, and finally camped at 3,100 feet on a densely timbered peak. Temperature at night, 58 degrees; noon shade, 72 degrees.

On the 8th we continued along the crest of the range towards the east until we reached the summit of the mountain overlooking Swallow's plantation at a height of 3,640 feet. Descending on the eastern slopes of that mountain we arrived at the plantation about 4 o'clock, and walked on twelve miles the same night to the camp on the Mulgrave.

()n the 12th, still leaving Messrs. Bailey and Broadbent collecting on the Mulgrave, I started for a final exploration of Bellenden-Ker, accompanied by Harold and three blackboys, Charley, Jimmy, and Toby. It was a flying trip in which the endurance of all was to be severely tested. On the first night we camped at the Whelanian Pools, and the next day reached our old camp on the summit, at 5,000 feet. Temperature at night, 42. degrees. Found the small stream from which we had previously obtained water was dried up, but we had brought a supply from 4,000 feet to guard against such a contingency. Next morning was cold and wet, when we started round the summit of the mountain, my intention being to traverse the whole range and descend by Mount Sophia. The entire mountain was covered by clouds, and nothing to be seen around or below us. Reaching the end of my previous track, I proceeded along the summit through dense wiry vegetation and confused masses of sharp rock, the crest of the range averaging 4,900 feet, rising at times to 5,000 feet, and in some places not six feet wide. We were all soaking from the drip of the trees and the wet bushes, and the boys felt the cold acutely. After five hours of hard continuous track-cutting, which nearly paralysed my right arm, we arrived close to the base of the north peak and camped at 4,900 feet, among tall trees and groves of tree-ferns. In the morning [ left the boys in camp and went ahead to see if they could be taken on. A quarter of a mile beyond the camp I came to piles and pinnacles of rock, with precipices on each side, and the eternal Dracophyllum growing from every crevice.

Leaving the gun and cane-knife behind, I lowered myself down from one rock to another, climbed on to those above by means of vines, and leaped across from boulder to boulder where a false step meant serious injury or death, until it was clearly seen there was no chance of going farther in that direction and taking the boys, without leaving every article we possessed at the camp. I had now been over every foot of Bellenden-Ker, including Sophia and Toressa, excepting the north peak on the edge of which I now stood, and decided to go back the way we came. We had but one day's provisions left, and it was my intention to submit the endurance of the whole party to a severe test. Leaving the blankets and all superfluous articles, we started to return.

We retraced the whole of the previous day's journey and reached the south peak about 12 o'clock. Then we started down the mountain and descended 4,000 feet on the long spur to the Whelaniani Pools, arriving there at sunset. We crossed the creek and ascended 700 feet, to the top of Barnard's Spur, and stayed all night in the blacks' camp. In one day we had actually covered a severe journcy for two days and a-half. That was an experience I would not care to repeat. 
On the 16th of August we left the summit of Barnard's Spur, descended 1,700 feet, and after a weary journey of eighteen miles arrived on the Mulgrave about $4 o^{\prime}$ clock in the afternoon.

On the 19th the whole party returned to Cairns, and on the 21st we went out to the Freshwater Valley, from which we came back on the 26th, leaving for Brisbane on the 27th by the "Waroonga," and arriving there on the 2nd September, after an absence of thirteen weeks.

We had done all we started to do, and a little more. The period of the year was the worst for both the botanist and the ornithologist. Mr. Bailey had to pass by a great number of trees and plants that only flower and fruit in the summer, but on the other hand he obtained specimens of many which blossom only in the winter.

His report, however, will show that he made a large and interesting collection of botanical specimens, including many entirely new to science, besides others discovered for the first time in Australia.

Geologically, there is little to report. Bellenden-Ker and Bartle Frere are composed almost entirely of granite, interspersed here and there by quartz reefs and slate. On the west side there were indications of tin, but careful prospecting might reveal the existence of other minerals. The creeks on both sides of the southern slopes of Bartle Frere contain gold, and considerable quantities have already been obtained by white men and Chinese. All the head waters of the Russell bring gold down from the Basalt Terraces. The alluvial gold-washing has so far been of the most superficial nature, most of the diggers being amateurs, with very primitive appliances. Many of them were assisted by the blacks, in whom a few reposed a blind unsuspicious confidence that cost them their lives.

The whole of the country travelled over, except the valley of the Russell, consisted of high steep ranges and deep ravines all covered by dense tropical jungle, and drained by steep granite creeks To show the extent to which that country is watered, it is only necessary to mention that between the bora grounds of Teechappa and Choonbine, a distance of ten miles, there are twenty-five running streams, some of considerable size. On the eastern face of Bartle Frere is a cataract falling sheer down over two thousand feet, visible for the whole length from the south peak of Bellenden-Ker. In the wet season it would clear a descent of three thousand feet. To that cataract I have given the name of the "Hume Black Falls," in honour of the present Minister for Lands. Every ravine in all parts of the ranges has its stream of pure cold spring water. The climate everywhere on the mountains is perfect, the fresh clear air unsullied by gases from decomposing vegetation such as you find in the rank undergrowth of the scrubs on the low lands of the river flats. There was no sickness whatever in camp during the whole period of the expedition. In many places there are magnificent facilities for hydropathic establishments, in climate and scenery unsurpassed in the world.

One year ago Cairns was visited by Dr. Alexander, health officer of Dunedin, in New Zealand, who went away with the impression that it possessed the best climate in Australia for people with weak chests or any form of throat or lung disease. We have irrefutable evidence of severe cases of long-continued asthma and incipient consumption, being perfectly cured by residence in the Cairns climate. There is a 
wide range of temperature and atmosphere between the sea-coast of Trinity Bay and the tablelands of the Upper Barron; or the cloudcapped summit of Bellenden-Ker.

The climate of the Cairns district on the sea level is one of perpetual heat and moisture. A seven years' residence on the Barron River revealed an average summer shade heat of 92 with a rare maximum of 104, and an average winter shade of 81 with a minimum of 54 . On the Bellenden-Ker range the summer shade heat is about 82 , the minimum temperature in winter about 29 . What is called "fever" in the Cairns climate is more frequently far more the outcome of gross indiscretions in diet or drink, or supreme ignorant contempt for ordinary hygienic laws, than the result of malaria or adverse climatic conditions.

It appears to be my duty here to settle the question of who was the first to ascend Bellenden-Ker, and $I$ am now in a position to decide, in a brief and summary fashion, so that there can be no room for further controversy.

There are two claimants, the one being Sub-inspector Johnstone who says he made the ascent in1873, and Mr. W. Sayer, who claims to have been on the summit in 1886. Mr. Johnstone's official report is before me. He started to Bellenden-Ker, from the Mulgrave River, with Mr: Walter Hill and eight troopers. His description of the vegetation, and the point at which he turned back, shows clearly that he reached only the summit of Mount Toressa, or the spur connecting it with Mount Sophia. He says, "We reached the centre peak of Bellenden-Ker at noon," when he was not within ten miles of the centre peak, nor couid he possibly have done in less than three days what he imagined he had done in one.

The fact is, he arrived there in the wet season, and all the peaks of Bellenden-Ker being under the clouds and invisible he somewhat hastily concluded that he had reached the top.

It will only be necessary to add here that Bellenden-Ker is practically inaccessible from the direction $\mathrm{Mr}$. Johnstone says he ascended, and presents precipices five or six hundred feet high. According to Mr. Johnstone's barometer, he reached a point in space far above the summit of Bellenden-Ker! Apparently, the instrument was one of decidedly eccentric habits, or else Mr. Johnstone finished his ascent in a balloon.

Mr. W. A. Sayer was a gentleman sent to Cairns by Baron von Mueller to collect botanical specimens, and if possible to ascend the Bellenden-Ker. The account of his attempts to reach the top forms a record of a series of ludicrous mistakes, perhaps unparalleled in the history of exploration. On the first effort he was out, six days from Harvey's Creek and failed to reach any particular locality. The second time he started to reach the mountain by going up the Russell River in a boat, and after thirty-four miles of navigation against a flooded river he was about ten miles farther from Bellenden-Ker than his point of departure. This time he was out about a month without reaching even the foot of the mountain, and he and his companions seem to have spent most of the time eapsizing themselves in the Russell and wandering about the scrubs, with no clothes on and nothing to eat, and not the remotest idea of their locality. 
He made a third start up Harvey's Creek, this journey including a semi-subaqueous walk of "eight miles up to their waists in the water of the flooded creek," to say nothing of vaulting up precipices seventy feet high, and falling from the top of others of even greater altitude; these remarkable acrobatics being performed after being "four and a-half days without food of any kind "! Mr. Sayer's disregard for food and the necessities of his epigastric region appears to have equalled his contemptuous indifference to the established laws of gravitation.

At 3,000 feet he and his party were saved in the middle of the night by "the violent barking of their dogs" from being murdered in cold blood by a band of hostile blacks. This is the first time blacks have ever been seen camped at that elevation. He made a fourth effort, and on this occasion he says he reached the summit and stayed there with a Mr. Davidson and four kanakas for eight and a-half days! Before learing the summit they "cut their names, date, and height on an Elæocarpus." The whole narrative is simply pure undiluted fiction, which one must sincerely and charitably hope is unintentional, and merely the natural outcome of Mr. Sayer's profound ignorance of bushmanship and the range he was attempting to explore. It remains for me to say that Mr. Sayer and Mr. Davidson never put a foot on any part of the summit of Bellenden-Ker, and that Baron von Mueller has incorrectly given the name of Bellenden-Ker to all the plants brought down by Mr. Sayer professedly from the summit of that mountain. I have been over the whole crest of Bellenden-Ker from end to end, the north peak alone excepted, without finding the remotest trace of any human being, black or white, and no mortal man could travel there without leaving tracks that would be visible for many years. There is no such tree as an elæocarpus on any part of the summit, and the supposition that six men could camp eight and a-half days there without leaving visible signs is really too preposterous to discuss. That Mr. Sayer and party were not on the north peak is a self-evident fact to me. His own account of the trip, as given in the Victorian Naturalist of July, 1887, shows that he reached, not the top of Bellenden-Ker, but the top of the eastward mountain previously mentioned, situated between Bellenden-Ker and the Russell, and forming no part of the Bellenden-Ker range. This mountain is 3,970 feet high, and called by the blacks "Chickaboogalla." On his return from Now Guinea I met Mr. Sayer in Cairns, and, referring to his alleged ascent, he said, "When we got on top of one peak we saw another above us, and beyond that another and another, and we did not reach the highest peaks after all, but I mean to go back again."

Now, this exactly describes "Chickaboogalla," and has no meaning at all when applied to Bellenden-Ker. Of course, at the last he saw peaks still higher, for the centre peak of Bellenden-Ker was 1,200 feet over his highest point of ascent. And so on the summit of "Chickaboogalla" Mr. Sayer collected all the plants which Baron Mueller erroneously credits to the top of Bellenden-Ker! It remains only now to say that Whelan, Barnard, and myself were the first who ever stood on Mount Sophia and the south peak of Bellenden-Ker; that Broadbent and myself were the first on the centre and highest peak; and that myself and Harold were the first to traverse the summit between the centre and the north peaks. This statement can be safely regarded as a final settlement of the whole question and one admitting no refutation whatever. 


\section{BELLENDEN-KER BLACKS.}

The blacks on the Bellenden-Ker ranges are about the same in general appearance and habits as the coast range blacks from Cardwell to Cooktown. As a rule they are short and wiry, with good chest development, thin legs, often slightly curved, and surprisingly small hands and feet. The gins frequently have hands no larger than those of a little girl of ten years of age. The small feet of both sexes upset the theory that walking barefooted enlarges the feet. They possess astonishing powers of endurance, and will walk incredible distances over rough country, carrying fifty or sixty pounds on their heads. Their food is chiefly vegetarian, varied occasionally by the flesh of the wallaby, the tree-climbing kangaroo, fish, birds, eggs, and three or four varieties of opossums. The koa nut, and other large nuts not yet botanically named, are the chief articles of diet. Some of the nuts and roots they eat are poisonous in their raw state, and these are pounded up and placed in dilly-bags in running water for a couple of days to have the poisonous principle washed out. Of edible nuts of various kinds they have an unlimited supply. In pursuit of treeclimbing animals they display an agility probably unsurpassed in the world, and probably not rivalled by any other Australian blacks. It would severely tax the reader's credulity to describe how these natives take a vine and run up the tallest trees, walk on to others across the branches, and descend sometimes a considerable distance from the starting point. Their main camps are always built on some healthy dry situation, beside or very near a running stream. These are the "wet weather camps," where they remain during the wet season, and store large supplies of nuts.

The blacks of this district vary in colour from a sooty black to a light bronze. Perhaps in no part of Australia is the Semitic type so startlingly distinct as among the tribes between Townsville and Princess Charlotte Bay. You see men and women who, apart from the colour, might be regarded as recent arrivals from Jerusalem. This is a deep and interesting problem for the Australian anthropographist.

We saw no camps higher than 2,000 feet, and very rarely any above 1,000 feet. These camps on high altitudes are only temporary, and usually consist of a few bent boughs covered over by fern or palm leares. At certain times they go up the mountains after the "mappee," the tree-climbing kangaroo, but never remain long. The nuts they chiefly live on are only found on the flats and in the valleys. There is little or no food on the mountains. On Bartle Frere we saw where tree grubs had been cut out at 3,000 feet, probably by Palmerston's boys. The blacks appear to shun Bellenden-Ker, there not being the faintest trace of them on any part of the mountain above 1,400 feet, except on Mount Toressa, where a clearly defined track crosses the spur at over 2,000 feet.

On Barnard's Spur, at 1,600 feet, there are three rows of holes dug out of the hard gravel, nine in each row. Each hole is about three feet deep, open below, with an arch connecting them at the top. These holes have been used in times gone by in some corroboree or religious ceremony, but I never saw them anywhere else. All these blacks are cannibals of a particularly bad type. They kill and eat their women and children, and occasionally they kill and eat their men. It is possible the custom arises out of an irrestrainable craving for flesh 
food, in a violent reaction against prolonged vegetarianism, and all Australian tribes have from time to time been addicted to the same practice. On many occasions I have seen conclusive proofs of cannibal feasts. They are in no way ashamed of the habit, and will sometimes chat about it in quite a jocular manner, and tell you what a great delicacy is a roast foot or a grilled hand. No women or boys are allowed to witness or join in the feast. When a gin is to be killed she is taken away to some secluded spot, one man seizes and crosses her hands in front, and another hits her on the back of the head with a nulla or a wooden sword. Then she is disembowelled, and cut up and roasted. Infidelity in a gin is punished by death. If a native falls from a tree or is seriously injured, he is generally killed and eaten. Their code of morality is stringent, but their social habits are indescribable, and their mode of living simply unimaginable. Plenty to eat is the one sole study of their existence. It forms the subject of their dreams by night, and stimulates all their faculties during the day. Occasionally they have compulsory fasts, followed by a period of excessive gormandising, and this accounts for the abnormally distended stomachs so frequently seen in all sexes, especially the women and children. The coast blacks have an unlimited supply of fish, and this they generally kill by the spear, with which they are very expert. The chief weapon of the mountain blacks is the wooden sword, a huge, unwieldy piece of flat wood, three feet long by four and five inches wide. They also throw stones with great dexterity. A myall armed with stones is about as formidable as one armed with spears. On the Russell Diggings large numbers of blacks have been acting as prospectors for the diggers, and were also very useful in carrying supplies to localities where it was impossible to take a packhorse. About 200 have also come in from time to time and worked on the Johnstone River plantations. Several diggers have been killed by the Russell blacks, who have also murdered three or four settlers on the Russell and Mulgrave. The blacks doubtless had their own grievances, and attempted to redress them according to their own theory of the wild justice of revenge. The whites killed were in all cases men ignorant of the nature of the savage, and blindly and foolishly credulous in their unreasoning faith in the wild children of the jungle. They became familiar with the blacks, trusted them implicitly, gave thein the tempting opportunity to kill, and the savage simply obeyed his natural impulse, and allowed the demon of destructiveness to control him under the suddenly farourable conditions.

It is the same old old story of death being the penalty too often paid by those who trust their lives to the delusion that the human savage differs essentially and radically in his nature from that of any other wild animal.

The tribal distinctions of these blacks are incomprehensible, and madness itself lies in the struggle to comprehend their confusion of tongues. A space of twenty miles will separate two tribes with different dialects. Each tribe has its own district, and dare not go beyond.

There are blacks on the Russell who never saw the sea except from the top of a mountain, and have lived all their lives within sixteen miles of the beach. If they cross their defined boundary they are killed, if not strong enough to kill the other party. They are never at a loss for a cause of quarrel which will afford a chance to kill and eat somebody. But in discussing the ferocity of the wild 
black, we may say, with Minerva to the Furies in Fischylus, "there being two present we have heard more than enough from the one side." In the debtor and creditor account of murder and outrage the balance is decidedly against the white man. Every white man murdered by blacks is represented by at least fifty blacks murdered by white men. The white man has, beyond all question, been the more unscrupulous and deliberate murderer of the two. The civilised man is simply the savage with a thin and plausibly attractive veneer over the surface. The savage usually kills out of a spirit of revenge for some real or fancied injury, past or present. Wholesale murder is yearly done by civilised men solely for the sake of gain. The civilised ruffian has no merit above the savage ruffian in the scale of humanity. The average white man is far above the average savage; the average savage is a far nobler animal than the lowest type of white men. We cannot judge the savage by our own standard of right and wrong, because his mind is moulded by different external influences operating in the direction of entirely different mental phenomena. In all cases the strong colonising race has treated harshly and contemptuously the weak race which it displaced. This is the history of all new countries, and the slaughter of the aboriginals by the invader is the one monotonously conspicuous fact in all the records of colonisation. No euphemism of expression or sentimentalism of thought can conceal that from the historian or the student of ethnology.

In all human progress and the transition and rise and fall of nations we see the all-ruling influence of the law of the survival of the strongest, a law probably synonymous with that of the survival of the fittest, on the assumption that the strongest are the fittest to survive. The Australian blacks are moving rapidly on into the eternal darkness in which all savage and inferior races are surely destined to disappear. All effort to preserve them, though creditable to our humanity, is a poor compliment to our knowledge of those inexorable laws whose operations are as apparent as our own existence. Their epoch of time is near its termination, the shadows deepening towards the everlasting night. It is a mournful picture, that of the old inhabitants who for unknown ages have roamed the primeval forests of this mighty continent, now muving off silent and stvift-footed into oblivion before the presence of the white strangers who walk over the graves of a dead race with as much unconcern as the blacks themselves trod over the rock sepulchres of the diprotodon and nototherium on the Darling Downs.

In obtaining the native names for prominent localities we have to face a difficulty in meeting a number of different names for the one place. Each mountain peak has its own name, and not only every valley and river and creek, but different parts of these have their distinct and characteristic titles. There is, therefore, a considerable amount of discretion required to avoid involving the names in hopeless confusion. Many of their names indicate by their sound some peculiarity in that on which they are bestowed. On the eastern side of J3artle Frere is a waterfall called "Chickaringadingadee," the name corresponding in a remarkable manner with the sound of the waters. The black cockatoo is called "karrna," in imitation of his harsh, discordant note. The Barron blacks call the dragoon bird "derrimderrim," and the Clarence blacks, in New South Wales, call the spur-winged plover " dibbin-dibbin," both birds having exactly the same peculiar movement in running. Occasionally two tribes use the same 
word to express an entirely different meaning. The Townsville blacks call the native companion (Grus australasianus) "boganburra," the name the Barron blacks give to the Nankeen heron. From the Barron to the Russell, a distance of forty miles, there are four names for the cassowary:-_" Boondarra," "keendadja," "bomba," and "goombajan."

Attached hereto are specimens of the dialects of the blacks of the Russell, Mulgrave, and Barron rivers, besides those of Townsville and the Clarence River, in New South Wales; the latter added partly to show there is not the remotest resemblance between the languages of the North Queensland blacks and those of the east coast of New South Wales. There is a total distinction between even those of Townsville and Cairns. I have also added a few names given me by one of the Tanna Island boys.

Man-banggan

Gin-yabbaroo

Old man-bókeebah

Old woman-choorgnaroo

Boy-burgnung

Girl-meetee

Hand-mulla

Arm-yeeko

Head-dinggi

Eye-kika

Nose-koho

Mouth-jowa

Teeth-teera

Tongue - jangoola

Foot-jinna

Calf-dagool

Knee-boonggo

Thigh-kallo

Stomach-bokay

Neck-goorka

Back一jooja

Breast-ohko

Beard-yoombo

Hair-moorah

Posterior-kanjan

Male privates-galloon

Female privates-bonjan

Spear-banggayi

Woomera-jarrin

Sword-banggal

Egg-churrowa

Cassowary-goombajan

Black snake-munungga

Hair-moora

Arm-kalkal

Head-woombo

Foot-boonjooroo

Hand-mulla

Toes-bigoon

Stomach-toobore

Tattoo marks-manjan

Leg-garra

Moon-kalkaloom
RUSSELL RIVER.
Camp-meetcha
Dillybag-janjo
Water-banna
Rain-jindi
Sun-currie
Moon-kakaloom
Stars-toolabo
Thunder-keekoroo
Lightning-jalmin
Crocodile-kanyahra
Scrub hen-jerrooga
Turkey-moon garra
Snails-koorajoon
Honey-minacheeam
Meston's bower bird-wargandilla
Spalding's orthonyx-chowchilla
Tree kangaroo-mappee
Cassowary-bomba
Wallaby-yooree
Possums-tula, yappee, and gnoota
Sea-berring
Mountains-cheeta
Corrobboree-yeékurri
Russell River-Mullin
Cockatoo-kyamboola
Dingo-goota
Nutmeg pigeon-kapparoom
Black cockatoo-karrna
Bellenden-Ker-Wooroonooran
Bartle Frere-Chooreechillum.

MULGRAVE RIVER.

Stars-toolabo

Sun-currie

Water-banna

Teeth-dirra

Tongue-tanggola

Eye-kika

Ear-manga

Nose-goa

Posterior-kanjan

Clouds-yeekan

Fire-boori

Smoke-wunjo

Thunder-chikoor 
MULGRAVE RIVER-continued.

Lightning-jogee

Wind-yooi

Night-goonda

Day-kappi

Grass-yakko

Rain-kappari

Cockatoo-wangolee

Turkey-googanggan

Sun-boonjan

Magenta-breasted pigeon-belbayan

Flock pigeon-boonboonboo

Scrub hen-boolagoo

Nankeen heron-boganburra

Wallaby-kanggoon

Alligator-kanyahra

Water-narraji

Quartz-joboor

Old man-boonjelman

Old gin-boolnaganman

Sleep-boojoora

Stars-yambowreega

Foot-dimbal

Hand-malboora

Spear-oonburra

Head-jalbooly

Boomerang-nunjal

Shield-goolmarrie

Nulla-noogoora

Woomera-wullaburra

Camp-tunby

Gin-murbal

Girl-wangum

Boy-moorda

Rock-boojooroo

Sun-malowan

Moon-bowaree

CLARENCE RIVER, NEW SOUTH WALES.

Squirrel一yongoo

Possum-woorarji

Native bear-wombooji

Kangaroo-yeegirbi

Dingo-wongo

Bandicoot-yingum

Swan-narragun

Geese-yoonamarum

Paddymelon-howhoon

Ducks-yelowul

Flying-fox-wolmba

Emu-yoogongwon

Native companion-booralgum

Plover-dibbin-dibbin

Wallaby-wokoori

W:illaroo-hoppi

Turkey - nurwhin

Black snake-muloo

Whip snake-munghine

Carpet snake-yoobool

Mouse-yoomoo
Parrots-kalbir

Wallaby-kangool

Sea-kilgi

Leach's kingfisher - gooranggal

Mulgrave-Koolgibberah

Russell-Kirrami.

BARRON RIVER.

Heron-warrumbool

Dragoon bird-derrim-derrim

Black cockatoo-karrna

Cassowary-boondarra

Banana-joonggool

Maize-coornam

Pineapple-jargan

Leichhardt-tree-mamboora

Bean-tree-joonggoora.

TOWNSVILLE.

Fire-mitta

Corrobboree-teerahna

Water-tunjan

Sea-beeroo

Swimming-yoongarrana

Ground-karadna

Flying-fox - boondagoraba

Emu-gondola

Turkey-cockabin

Crocodile--tuckanang

Dog-ooda

Cockatoo-bulgena

Wallaby-gargoon

Kangaroo-woorda

Duck-bornja

Boy child-ahboon

Girl child-yoongurra

Good bye-goondawya.

Mountain-yarmun

Rock-dumbam

Grass-yooravagum

Ground-woteher

Tree-yooleejir

Thunder--yurroway

Rain-wooloon

Water-narroo

Fire-muttunggul

Sea-cockul

Sun-nowhoon

Moon-wooraljir

Stars-wooralgum

Old man-yooloorie

Boy-yarganine

Young man-murrawanjin

Young wife-combunegwon

White woman-yirrarliemirgin

Ghost-wurrum

God-yoolootahna. 
TANNA ISLAND (PACIFIC).

Thunder-carroorawa

Lightning-lomo'ophil

Moon-mokwa

Sun-mary

Stars-cum'mahow

Ground-tenna

Rock-cab'beeil

Fire-naup

Trees-mayee

Fish-nahmoo

Coral-bish'eea

Sky-neei

Clouds-nap'owa
Water-nooi

Mountains-dag'gooil

Pigeons-man'oo

Rivers-nokwotenna

Man-yermamma

Woman-perran'

Boy-yoganow'ee

Girl-prenowee

Old man-yengala

Old woman-branheema

Wind-matang ${ }^{\prime-}$

Rain-neershan'

Volcano-lummahook.

\section{THE HERBERTON LAKES.}

On the tablelands of the Upper Barron, at an altitude of 2,300 feet, are two large freshwater lakes. One of these lies about three miles from Boar Pocket, on the Cairns-Herberton road, and the same distance to the south of that road. The blacks call this lake "Yeetcham," and the one seven or eight miles beyond, to the south-west, they call "Boonoobagolomee." My visit to Lake Yeetcham was during heavy rain, and I remained there just long enough to examine the position, and no more. This lake is about a mile and a-half long, by a mile across. It is surrounded by a circular ridge about a hundred and fifty feet above the water, and covered by dense scrub. On arriving at the top of this ridge and looking towards the lake, you appear to be gazing at the inverted sky, the impression being that of having arrived at the edge of some colossal precipice, with the blue empyrean stretching far down into bottomless vacuity. Descending the steep side of the ridge we arrived on the shore of the lake, a magnificent expanse of beautifully calm clear water, like an inmense mirror, edged by the splendid border of rich dark-green tropical vegetation, where the "trees sloped downwards to the brink and stood with their green faces fixed upon the flood."

Over all there hung a silence that was oppressive. No fish rippled the glassy surface, no bird plumed his ruffled wings or called his mate from out the shore recesses. There was not a sign of bird or beast, save an animal like a huge iguana that swam out from the edge, gazed at us a few seconds, and vanished.

Apparently a perfect paradise for wild fowl, there was not a feather to be seen from shore to shore. There may be some marine fish or animal there fatal to bird life. A surveyor who was camped by the side of "Boonoobagolomee" told me that he could hear at night a ripple on the beach and the wash of a wave made by some large animal, probably a fish, as there were no shore marks to indicate the presence of an amphibian.

It is more than likely those lakes will yet reveal forms of life intensely interesting to science. Their inhabitants are so far totally unknown. Around Yeetcham is a perfectly watered country of rich soil covered by dense scrub broken here and there by open "pockets" and low forest ridges. The climate is not surpassed in Australia for its equable temperature and pure salubrious atmosphere. With villas and gardens round the shores, this lake would form one of the loveliest 
scenes in the world. What a glorious place for regattas and rowing and salling and pleasure parties, where the spectators could stand on the crest of the surrounding ridge, in the dress circle of Nature, and look down upon the superb marine stage where the gay performers held high festival across the azure floor! It would excel any of the Swiss or Italian lakes in loveliness or surrounding advantages. That lake country of the Barron tablelands is the future tropical garden and sanatorium of Australia.

Lake Boonoobagolomee is about the same size as Yeetcham. Their depth is at present unknown, but a surveyor went out on the former on a catamaran and fathomed in one place at 275 feet. They are not, as at first supposed, the craters of extinct volcanoes, there being no trace of volcanic action more recent than the formation of the tableland itself. The bottom will probably be found level with the surface of adjoining valleys Iying outside the surrounding spur which encloses the waters of the lake; that is, from 200 to 400 feet in depth. The water is pleasant to drink and beautifully clear. Black sand was visible mixed with the clay along the margin. The blacks speak of a third lake much smaller than the others, but so far it has not heen seen by white men.

\section{TIMBERS OF THE DISTRICT.}

There is no part of Australia where so little is known of the nature, the rarieties, and the quantities of arailable timbers. The vast scrubs of the Upper Barron, overlooked by the Bellenden-Ker Range, contain a wealth of trees no less astonishing in their diversity than the apparently incalculable amount of timber they represent. Those scrubs are certainly to be the source from which Queensland must draw her future choicest woods.

On the coast ranges between Cardwell and Cooktown the timbergetter will be drawing the nation's supplies from the steep spurs and dark ravines long after the natural forests of the rest of the colony are exhausted. There also will be found the last surviving pine and cedar. On the Bellenden-Ker Range itself there are great quantities of valuable timber, at present presumably inaccessible, but which in years to come, when timber is dear and scarce, will be brought down like pines from the even more unpromising mountains of Norway and Switzerland. On all the spurs are large hardwood trees, unknown by either local or botanical names.

The kauri pine, of gigantic size, is found up to 4,800 feet. There is no red cedar on either side of "Wooroonooran," save a small patch at the foot of the north spur below Toressa. Here I may mention one most peculiar eccentricity of nature in the distribution of this beautiful timber. Cedar grew in great quantities along both banks of the Mulgrave and the Johnstone Rivers, but not a solitary tree has ever been found on the Russell, which lies midway between them, and actually flows into the Mulgrave a mile before entering the Pacific. The Bellenden-Ker Range divides the Mulgrave and Russell, but there is no range between the Russell and Johnstone. Nor is there any perceptible cause for the remarkable total absence of cedar on the Russell, the soil and climate being exactly the same as the rivers on each side. 
Langdon's hardwood, of the Johnstone, named Backhousia Bancroftii by Mr. Bailey, comes across from that river and down the valley of the Russell in incalculable quantities, and up the valley of the Mulgrave for about five miles from Harvey's Creek, and then suddenly ceases, not a tree known to be growing anywhere north of that point. It is a very hard tree, with fluted trunk and numerous flanges, usually splits freely and burns well.

From 3,000 feet to 5,000 feet on Bellenden-Ker there are many timbers totally unknown, some with beantiful grains, some tough as whalebone, and others, when cut, diffusing remarkably pleasant perfumes, the wood and bark strongly aromatic. All the trees on the summit of the mountain, small and large, are intensely hard, some of them rivalling even the grey ironbark (melanophloia).

On the forest spurs of the main range, extending down on to the flats, are large quantities of Moreton Bay Ash (E.tesselaris), which is there much more durable than the same tree in Southern Queensland. The bloodwood (E. corymbosa) is also found along the face of the range, but usually small and hollow, far inferior to the bloodwood on the rivers of the South. In the river beds of the Barron and Mulgrave the swamp oak (Casuarina glanca) grows to perfection-a tall, stately tree, beautifully grained.

The stinging tree of North Queensland, moroides, is only a bush, never growing into the trees of four and five feet in diameter like gigas found in the coast scrubs of South Queensland and New South Wales, but far more virulent in its effects. There is one mild species which attains a diameter of six to twelve inches. The kauri pine ( $A$. robusta) extends from the river scrubs right on to the tops of the highest peaks of the coast range, and grows to enormous size on the Upper Barron, in the red cedar country, many of the trees eight and nine feet in diameter. The walking-stick palm (Ptychosperma Normanbyi), common on the Mosman and Daintree, is not found, so far as I am aware, south of Port Douglas. In place of it we find the "Piccabeen" palm in great perfection, the magnificent fan palm (Licuala IMuelleri), and on the tops of the ranges a superb widespreading palm which Mr. Bailey will refer to in his report. It has a very hard stem, grows about twenty feet high with leaves ten to fifteen feet in length, shading all beneath it like an umbrella. On the range at the head of the Little Mulgrave, at 3,000 feet, I passed through a complete grove of this indescribably beautiful tree, all flowering and fruiting.

This is an appropriate opportunity of respectfully suggesting to the Government the earnest desirability of having specimens of all the Bellenden-Ker and Upper Barron timbers collected and classified as soor as possible, so that the colony can know the quantity and quality and value of its timber resources. It is also highly desirable to obtain some knowledge of the medicinal value of the Queensland flora. A competent chemist could prepare extracts and infusions, of which the properties could soon be ascertained by our medical men in a course of judicious experiments. Already the Eucalyptus family has proved itself one of the most valuable known to mankind, and who shall say with what splendid gifts the Queensland flora can reward the medical science if properly investigated? The Colonial Botanist is satisfied there are quite as many timbers in Queensland as the whole 
of India, about a thousand species, and yet so far he has only been afforded a chance of classifying a little more than one-half.

On the ranges at the head of the Little Mulgrave and Freshwater Creek, there are countless numbers of a giant hardwood-tree that I never saw anywhere else. It usually varied in size from three feet to seven feet in diameter, with a tall clean trunk going straight into the ground like a kauri pine. On parts of the summits of all the ranges I traversed there were patches of dead trees showing no traces of lightning, and yet standing in localities where there was no possibility of injury from fire. My opinion is that nearly all of them had expired of old age. Their long bare gray branches stood out in funereally mournful relief against the rich deep green of the surrounding tropical foliage. On Bellenden-Ker there were many dead and dying specimens of the beautiful dome-shaped tree, which Mr. Bailey tells me belongs to the myrtle family, and will probably be found to be an entirely new species.

In the valleys of the Russell and Mulgrave, and all along the ranges up to about 2,000 feet, there are vast quantities of Castanospermum australis, the Moreton Bay chesnut, a tree common as far south as the Clarence River, where its beauties as a cabinet wood were first proclaimed twenty-six years ago by the late Robert Muir, of Nerang Creek. I am not aware how far this tree extends along the Cape York Peninsula. The beans are fatal to stock when eaten repeatedly, but the blacks use them for food after extracting the poisonous principle by maceration in running water in the usual way. Samples sent home in the log from Cairns were pronounced by the London timber merchants equal to the finest pollard oak.

Among the timbers of that district will certainly be found some not excelled in the world for beauty in cabinet and fancy work, and there are just as surely others which will successfully answer all the purposes for which Australia is now importing timber from foreign countries. I have no hesitation in prophesying the discovery there of trees in all ways perfectly adapted to every object for which woods are utilised by mankind.

And the sooner we possess a complete knowledge of all our timbers the less the sacrifice our ignorance of the present will compel us to make for the benefit of an ungrateful future.

Yours, with respect,

ARCHIBALD MESTON.

I reproduce here my description of the scene witnessed from the south peak of Bellenden-Ker in February, when I made my first ascent of the mountain :-All was distinctly visible, in the perfectly clear atmosphere, in a radius of, at least, 100 miles in all directions. We were silent in the awful presence of that tremendous picture that had lain there unaltered since Chaos and the Earthquake painted it in smoke and flame and terror in the dark morning of the world! It was a hall of the Genii of the Universe, the Odeon of the eternal gods, with its immortal floor paved with the green mosaic of land and ocean, and overhead the arched blue roof flashing in diamonds and prismatic radiance to the far sky-line on the edge of the dim horizon. 
Eastward rolled the calm Pacific, visible from the Palm Islands in the south to the vicinity of Cooktown in the north. The white surf breaking on the Barrier Reef was a long white line on the lovely azure of the slumbering ocean. The towering peaks of Hinchinbrook looked down on the cone-shaped islands of Rockingham Bay and the valley of the Herbert; behind them the dark-blue serrated ridges of the Cardwell Range. To the north Cairns nestled in calm seclusion on the shores of the beautiful bay, a white oasis in the desert of blue haze. Green Island, Fitzroy, High Island, and the Franklyns, were as emeralds set in the lapis lazuli of unruffled ocean, the bleached coral beaches girdling them with a white zone on which the dying waves expired in long ripples of snowy foam. Between us and the ocean was the valley of the Russell, with its reed-covered plains and mysterious lakes, and the river winding in sinuous curves like a vast silvery serpent through the dense dark-green tropical jungle, down to where it joined the Mulgrave, and the united waters rushed together into the sea. North-east was the valley of the Mulgrave, ending in the beautiful plains beneath the long evening shadows of the conepeaked Walsh Pyramid. From where the range dipped into the sea at Double Island, north of Cairns, away west to the hills on the head of the Gulf waters, and south to where the eye lost itself in distance, was a vast indescribable panorama of hills and valleys and mountains of every conceivable shape, and to the west the wavy sea of magnificent country on the Herberton tablelands, the future garden of Australia, with its regular rainfall, rich scrub soil, and glorious climate. This site of the volcanic lakes was marked by their covering sheets of snowwhite mist. In all the ravines along the face of the coast range were blocks of beautiful amber cloud, reposing there like white-winged birds weary of tossing to and fro in the combat of warring winds. Mount Sophia and the dark north peaks of the Bellenden-Ker stood facing us in gloomy grandeur, in that dread silence which is more terrible to the soul than the crash of thunder, the roar of breakers, or the diapason of the cannonade. South-west, immediately in front, stood the majestic form of Bartle Frere, divided from us by a chasm 4,000 feet in depth, and four or five miles across from peak to peak, a wild and dismal solitude peopled by the storms alone. Deep abysmal gorges, gloomy ravines, and carerned mountains dark as the realms of Pluto, grim rocks in unimaginable shape; far down through the immeasurable grey void the subdued rush of falling water, weird echoes rising from the depths below as if one could hear "a march as of the earth-born Forms arrayed against the ever living gods !" and around and over all, in one dark green wide-spreading mantle, the wonderful tropical jungle, infinite in its shapes and hues, the robe of Nature woven with sunbright colours in the looms of God! And then there passed before us a scene such as we never saw before and may never see again. From behind Bartle Frere there came slowly drifting towards us a vast white sulphurous storm-cloud charged with thunder and lightning. It entered the abyss between us and Bartie Frere, hung suspended there at least 2,000 feet below where we stood, and we looked down from our lone tree-tops in voiceless amazement at a thunderstorm raging in uncontrolled madness far beneath. Lightning shot out in awful flashes downward and upward, followed by appalling thunder. Detached fragments of spectral cloud came drifting up from the storm and shot athwart the mountain top, rushing by us with a weird 
"swish" like a column of cold damp fog driven by a sudden blast. And then the winds from the south-east turned the storm away along the valley to the north, and the "Lion of the Skies" vanished slowly in the distance, his deep-toned voice making the mountains tremble, and his fierce eyes flashing electric fire. We camped all night on the summit. What wonder that in such a place, "obscurely through the brain swept awful thoughts,"

Which through the deep and labyrinthine soul,

Like echoes through long caverns, wind and roll!

We were denizens of the upper air. With Goethe we knew the "Stars silent above us; Graves silent below us." The fauna and flora of this strange mountain, according to De Vis, are the oldest on the Australian continent. It is the Ararat of the Pacific. Here are plants found hitherto only on the summits of the Himalayas. Ah heaven! why cannot some fossil relate to us the story of the vanished Ages from the death silence of his stone mausoleum? I gazed on the storm, and in imagination saw "a Spirit with a dreadful countenance check his dark chariot by the craggy gulf," and some Idran Ganymede pour out his celestial rain of wine from an exhaustless urn upon the grateful earth! Round the base of this mountain once roamed the giant Diprotodon and the colossal Nototherium. Iguanas 30 feet in length crawled through the primeval vegetation on the plains below, and the marsupial lion, Thylacoleo, crunched the bones of his herbivorous victims in the dark secluded caves. Around us was the silence of departed Time, of voiceless Eternities, of worlds beyond the morning stars! I seemed to see the shadows of the unborn Centuries reflected on the azure mirror of the night, and shadows of the past vanishing like misty spectres in the impenetrable gloom. In the tree-tops we heard the wailing of the "huge winds that sweep from Ursa Major to the tropics and equators, dancing their giant waltz through the kingdoms of Chaos and Immensity." And they play wild Memnonian music on the mountain's grand old Folian harp of pines !

I have, \&c.,

A. MESTON. 


\title{
BOTANY OF THE BELLENDEN-KER EXPEDITION.
}

\author{
Colonial Botanist's Office, \\ Brisbane, 7th October, 1889.
}

Sir,-In accordance with your instructions in a letter dated 1st June, that I should accompany Mr. A. Meston to the BellendenKer Range, and collect and report on the Flora of the district, I have the honour to report that I left Brisbane on the 4th June en route, and returned on the 5th September, bringing with me a large number of specimens, which will make a most valuable addition to the Herbarium.

In the accompanying Report will be found a classified account of all the plants which could be identified from the Mulgrave River to the summit of Bellenden-Ker, together with those of Bartle Frere and Harvey's Creek; the several localities being indicated by numbers. All new species are fully described, and descriptive and other notes given where such are required; the native or common name is also given of the plant where such could be obtained. No purely alpine plants were met with, which is scarcely to be wondered at, when the limited extent of the range is considered, the greatest altitude only just exceeding 5,000 feet above sea-level. Some of the most common plants of the summit are identical with those of the Brisbane district. The results of the expedition, however, from a botanical point of view have proved highly satisfactory; about thirty fresh plants have been added to the known Flora of Australia, equalling in number those added to the Flora of New Guinea by Sir William McGregor's late expedition to the Owen Stanley Range, which is about three times the height of Bellenden-Ker, and proportionately extensive in area. It being winter, a large number of the trees and shrubs were without flower or fruit, consequently could not be identified.

In the Report now submitted, with the exception of a few, all the Phænogams with the Ferns and their allies are recorded. The large number of Mosses, Lichens, and Fungi which I collected will be arranged and forwarded to specialists with whom $I$ am in communication for final determination; and amongst these I expect will be found many additional species to those already known, which will be included in a future supplement to "The Queensland Flora."

I have the honour to be,

Sir,

Your obedient servant,

F. M. BAILEY,

Colonial Botanist.

The Hon. The Secretary for Public Lands. 


\section{BOTA NY.}

The figures at the end of the general references indicate localities as follow:-

1, Tringilburra Creek; 2, Whelanian Pools ; 3, Palm Camp ; 4, Bellenden-Ker ;

5, Harvey's Creek; 6, Bartle Frere; 7, Mulgrave River.

\section{Class I. DICOTYIEDONS.}

\section{Order RANUNCULACEE.}

CLEMATIS, Linn.

C. glycinoides, $D C$.; Syst. Veg. i. 145; Fl. Austr. i. 7. Virgin's Bower. 1, 5, 7 .

\section{Order DILLENIACEAE.}

TETRACERA, Linn.

T. Nordtiana, F. $v$ M. ; Fragm. v. 1. 1, 7 .

DILLENIA, Linn.

D. Andreana, F. v. M.; Fragm. v. 175. 5.

WORMIA, Rottb.

W. alata, $R . B r$. in DC. Syst. Veg. i. 434; Fl. Austr. i. 16.1.

HIBBERTIA, Andr.

H. velutina, $R$. Br.; Fl. Austr. i. 30 . Shrub, all parts clothed with a whitish velrety tomentum; height, 4 to 5 feet, and spreading; branches prominently angled. Leaves oblong-ovate, 1 to nearly 2 in. long, 3 to 7 lines broad, much tapermg towards a petiole of about a line long; midrib very prominent, lateral veins patent and distinct, margins recurved. Peduncles axillary near the ends of the branches, flattened, $\frac{1}{2}$ to $\frac{3}{4}$ in. long, with a narrow bract close under the calyx. Sepals 3 or 4 lines long, outer ones acute, inner ones obtuse, and wider. Petals broadly obovate, about $\frac{1}{2}$ in. long; stamens numerous; carpels 3 , at first silky then rather echinate, 2 -ovulate.

Hab.: On summit of Mount Harold, off Tringilburra Creek, and Walsh's Pyramid, Mulgrave River.

H. volubilis, $A n d r$; Bot. Rep. t. 126 ; Fl. Austr. i. 37. 1, 7.

\section{Order MAGNOLIACEZE.}

DRIMYS, Forst.

D. membranacea, F. v. MI.; Fragm. v. 175. Northern Peppertree. 7 .

\section{Order ANONACEE.}

CANANGA, Rumph.

C. odorata, Hiok. and Thoms.; Ind. Flora. 7. 
EUP0MATIA, R. Br.

E. laurina, $R$. Br.; Flind. Voy. ii. 597, t. 2.; Fl. Austr. i. 54. 1, 7. E. Bennettii, F. v. $M$.; Fragm. i. 45; Fl. Austr. i. 54. 1, 7.

\section{Order CRUCIFERAE.}

\section{CAPDAMINE, Linn.}

C. hirsuta, Linn.; DC. Prod. i. 152; Fl. Austr. i. 70. Bitter Cress. 7.

\section{Order VIOLARIEE. \\ IONIDIUM, Vent.}

I. suffruticosum, Ging. in DC. Prod. i. 311; Fl. Austr. i. 101. 7.

\section{Order PITTOSPOREAE. \\ PI'TOSPORUM, Banks.}

P. Wingii, F. v. MT. in So. Sc. Rec., March, 1855. 3, 4 .

P. rubiginosum, A. Cunn. in Ann. Nat. Hist. ser. i. iv. 108; Fll. Austr. i. 112. 1, 7.

CITRIOBATUS, A. Cunn.

C. multiflora, A. Cunn. in Loud. Hort. Brit.; Fl. Austr. i.121. 2.

Order POLYGALEAE. XANTHOPHYLLUM, Roxb.

X. Macintyrii, F. v.M.; Fragm. v. 57. 2.

\section{Order PORTULACE正.}

PORTULACA, Linn.

P. oleracea, Linn.; DC. Prod. iii. 353; Fl. Austr. i. 169. Pigweed. 5,7 .

\section{Order GUTTIFERZ.}

\section{GARCINIA, Linn.}

G. Mestoni, n. sp. Meston's Mangosteen. (After A. Meston, the leader of the expedition to Bellenden-Ker.) An erect, slender, graceful tree of 20 or more feet; branches drooping. Leaves glossy dark-green, opposite, narrow-lanceolate, the points much elongated, 2 or 3 in. long, somewhat wary but with entire edges; petioles slender, $\frac{1}{2}$ in. or more long. Flowers (only a few very early buds seen, and these much injured by insects) probably small, either terminal or leaf-opposed, nearly sessile, with a few small bracts at the base ; sepals 4 , small, imbricate; petals white, and seem to be hairy. Fruit depressed-globular, a pleasing green, 2 in. diameter, but not fully grown, 8-celled; seeds somewhat rugose; stigmatic lobes 8 , closely sessile on the fruit; the sepals closely appressed, persistent under the fruit, and probably not much enlarged.

Hab : Bellenden-Ker Range, at an altitude of 2,000 feet.

Fruit of this tree were gathered in the ripe state by Messrs. Meston and Whelan on their first ascent of Bellenden-Ker, and they describe the fruit as possessing a sharp, pleasant, acid flavour and very juicy, about 3 in. in diameter. 


\section{Order MALVACEAE. \\ MALVASTRUM, A. Gray.}

M. tricuspidatum, A. Gray; Pl. Wright, and Bot. Amer. Expl. Exped. i. 148; Fl. Austr. i. 187. 7.

\section{SIDA, Linn.}

S. virgata, Hook. in Mitch. Trop. Austr. 361 ; Fl. Austr. i. 194. 7. S. rhombifolia, Linn.; DC. Prod. i. 462; Fl. Austr. i. 196. Sida-weed. 7.

\section{URENA, Linn.}

\section{U. lobata, Linn., var. grandiflora; Fl. Austr. i. $206 . \quad 1,7$.}

This plant, which is rery abundant on the borders of many of our tropical scrubs, yields a strong fine fibre, which in India is considered a good substitute for flax.

HIBISCUS, Linn.

H. Manihot, Linn.; DC. Prod. i. 448; Fl. Austr. i. 210. 1, 7.

II. brachysiphonius, F. v. M.; Fragm. i. 67; Fl. Austr. i. 210. 1.

\section{BOMBAX, Linn.}

B. malabaricum, $D C$; Prod. i. 479; Fl. Austr. i. 223. Silk Cotton tree. 7.

There are two forms of this tree growing in the Mulgrave River scrubs, the one with and the other without prickles on the trunk and branches; but haring seen no flowers or fruit, I cannot say if they are distinguishable by other marks.

\section{Order STERCULIACE FE. \\ TARRIETIA, Blume.}

T. Argyrodendon, Benth.; Fl. Austr. i. 230. Stavewood. 1.

T. trifoliolata, var. peralata, Bail.; Second Suppl. Syn. Queensl. Fl. 10. Red Beech of the North. 1.

\section{HERITIERA, Ait.}

I. littoralis, Ait.; DC. Prod. i. 484; Fl. Austr. i. 231. Red Mangrove. 5, 7 .

\section{ABRONA, Jacq.}

A. fastuosa, R. Br.; DC. Prod. i. 485; Fl. Austr. i. 236 . A ustralian "Devil's Cotton." 1, 7.

As a fibre-producing plant probably none could be grown to greater advantage. It is of rapid growth, will attain the height of 12 or more feet in a rery short time, and the fibre is very strong and abundant and easily prepared. In several localities we found it very abundant, and made use of the fresh-stripped bark for string. Another species of the genus-A. augusta, Linn.-is known in India as the "Devil's Cotton," the fibre of which is considered nearly equal to bemp and not to suffer injury when exposed to wet.

\section{Order TILIACE EE.}

GREWIA, Linn.

G. polygama, Roxb.; Fl. Ind. ii. 588; Fl. Austr. i. 271.1. bark.

The natires make use of the fruit for food, and obtain their string from the 
G. pleiostigma, F.v.M.; Fragm. viii. 4. 7. This is a diœcious tree attaining the height of 40 or 50 feet; the trunk seldom exceeds 8 or $10 \mathrm{in.} \mathrm{in} \mathrm{diameter,} \mathrm{and} \mathrm{being} \mathrm{very} \mathrm{light,} \mathrm{straight,} \mathrm{and} \mathrm{of} \mathrm{con-}$ siderable toughness, is frequently used for rough fencing, \&c. The bark yields good fibre; the leaves are large, often measuring 9 in. long and 5 in. broad.

The wood of this tree, on account of its elasticity and toughness, may in a few years be in demand for the manufacture of oars, shafts, and other purposes where strength and elasticity are required, for which many other species of this genus are found valuable in India.

\section{TRIUMFETTA, Linn.}

T. rhomboidea, Jacq. ; DC. Prod. i. 507 ; 2nd Suppl. Syn. Queensl. Fl. 11. Chinese Burr. 5 .

A pest known too well in most warm countries, now fast spreading over the Northern lands. Supposed to have been introduced by the Chinese amongst vege. table seeds.

ARISTOTELIA, I'Hér.

A. megalosperma, F.v.M.; Fragm. ix. 84. 5.

\section{ELFOCARPUS, Linn.}

F. grandis, F. v. M.; Fragm. ii. 81; Fl. Austr. i. 281. Quandong or "Kurroogi." 1,2.

E. Bancroftii, Bail. and F.v. M..; Proc. Roy. Soc. Queensland. 2. Kernel of the fruit edible, and timber useful.

\section{Order GERANIACER.}

OXALIS, Linn.

O. corniculata, Linn.; DC. Prod. i. 692 ; Fl. Austr. i. 301. Yellow Wood-Sorrel. 5, 7.

\section{Order RUTACEE. \\ MELICOPE, Forst.}

II. chooreechillum, n.sp. (Aboriginal name for Bartle Frere.) A large shrub or small tree, glabrous, branches thick. Leaves opposite, of unequal size in each pair ; petioles 1 to $2 \frac{1}{2}$ in. long, sulcate on the upper side; leaflets 3 , obovate, tapering from a broad emarginate end to the top of the petiole, $1 \frac{1}{2}$ to 3 in. long, $\frac{3}{4}$ to $1 \frac{1}{4}$ in. broad, of a thick cartilaginous or coriaceous texture; veins faint in the fresh leaf, but prominent in the dried specimens, the primary ones anastomosing far within the margin, the under surface closely covered with small dots (oil-dots). Flowers in short trichotomous panicles, length of the petioles, pedicellate; sepals 4 , obtuse, minute ; petals 4, about 4 lines long, linear, white, thick, the apex incurved ; stamens 8 ; filaments broad at the base, very nearly glabrous; anthers oblongrotund; disk a yellow ring; ovary glabrous, 4-celled; style hairy on the lower half; stigma shortly 4-lobed.

Hab: Summit of Bartle Frere. In some respects this fresh species is allied to Evodia Fareana, F. v. M.

EVODIA, Forst.

E. alata, F. v. $\mathbb{M}$.; Fragm. vii. 142. 1, 2, 7.

E. accedens, Blume; Bijdr. 246; Fragm. vii. 142. 1, 7 . 
ZANTHOXYLUM, Linn.

Z. torvum, F. v. $M$.; Fragm. vii. 140. 7 .

\section{ACRONYCHIA, Forst.}

A. acidula, F. v. M.; Fragm. iv. 154. Scortechini's Crab. 1.

This produces a pleasant acid fruit, which might be utilised in forming cooling drinks. A form of the species is met with on the Logan, and the usefulness of its fruit was brought under notice some years ago by the late Rev. B. Scortechini.

\section{MICROMELU M, Blume.}

M. pubescens, Blume; Oliv. in Journ. Linn. Soc. v. Suppl. 40; Fl. Austr. i. 368. The Lasmani of India. 7.

\section{CITRUS, Linn.}

C. inodorus, n. $s p$. North Queensland Lime. 5. (Named from the flowers wanting fragrance.) A tali shrub; the young branches flattened or more or less angular as in the common orange. Spines not very numerous, about $\frac{1}{4}$ in. long, erect, 1 or 2 at the axils of the leaf. Leaves lauceolate or ovate-lanceolate, with distant sinuous crenations, 3 to 7 in. long, $1 \frac{1}{2}$ to 2 in. broad in the centre, the apex often elongated, and tapering towards the base to a very short petiole seldom exceeding $\frac{1}{4}$ in. in length; substance coriaceous ; midrib and primary veins more or less prominent, the latter rather close and anastomosing in an intramarginal vein. Flowers axillary, nearly sessile, and, so far as observed, scentless; calyx of 5 minute teeth; petals 5 , about 3 lines long, spreading; stamens free, over 30 , of irregular length, shorter than the petals; ovary, with style, scarcely exceeding a line in length. Fruit oblong, $2 \frac{1}{2}$ in. long, $1 \frac{1}{4} \mathrm{in}$. diameter, showing 8 obtuse ribs, the divisions of the fruit; pulp a sharp agreeable acid; seeds oval, somewhat flattened on one side, convex on the other, 3 lines long, 2 lines broad; testa white.

Hab. : Harvey's Creek, Russell River.

This new species of Citrus is well worthy of cultivation for its fruit, which is juicy, and of equal flavour with the West Indian Lime. In general appearance the tree resembles the orange, having the same dark-green foliage. I have chosen the specific name on account of all the flowers gathered being wanting in fragrance, a remarkable feature in a genus so noted for scented flowers.

\section{Order MELIACEE.}

MELIA, Linn.

M. composita, Willd.; W. and Aru. Prod. 117 ; Fl. Austr. i. 380. White Cedar. 1.

DYSOXYLON, Blume.

D. Schiffneri, F. v. M. in Melb. Chemist, 53. 5.

D. rufum var. glabrescens, Fl. Austr. i. 382. 7.

D. Klanderi, F. v. M. ; H'ragm. v. 176. 1, 5.

CEDRELA, Linn.

C. Toona, Roxb.; Pl. Corom. iii. 33, t. 238 ; Fl. Austr. i. 387. Red Cedar. 1. 


\section{Order CELASTRINEÆE.}

\section{DENHAMIA, Meisn.}

* D. viridissima, Bail. and $F$. $v . M$. A small tree with dense head of dark-green foliage Leaves alternate or nearly opposite, often clustered at the ends of the branchlets, lanceolate, 3 or 4 in. long, 1 to $1 \frac{3}{4} \mathrm{in}$. broad in the centre, tapering to a very short petiole, the apex more or less elongate, margins entire, green on both surfaces, and the reticulation more or less prominent. Flowers in terminal pedunculate cymes or racemes, but the tree only met with in early fruit; capsules 3-valved, somewhat fusiform, prominently obtusely 3 -angular, 1 to $1 \frac{1}{2}$ in. long, bursting loculicidally, bearing the seeds on the prominently projecting placentas; seeds 4 to 6 to each placenta, half enclosed in a rather large fleshy arillus.

Hab. : Bellenden-Ker.

ELEODENDRON, Jacq. $\mathrm{f}$.

E. melanocarpum, F. v. MI.; Fragm. 62 ; Fl. Austr. i. 403.7.

HYPSOPHILA, F. v. M.

H. Halleyana, $F$. v. $M$.; Vict. Nat. 1887; 2nd Suppl. Syn. Queensl. Flora, 15. 4.

SIPHONOION, Griff.

S. australe, Benth.; Fl. Austr. i. 403. Ivorywood. 1. The fruit seems to be larger and more globose in the tropics.

\section{Order RHAMNEA.}

\section{POMADERRIS, Labill.}

P. elliptica, Labill.; Pl. Nov. Holl. i. 61, t. 86 ; Fl. A ustr. i. 417. Walsh's Pyramid. It is probable that the flowers are apetalous, for in all those $I$ have examined they were wanting.

\section{GOUANIA, Linn.}

G. australiana, F.v. M.; Fragm. iv. 144. 7. Of this extensive tomentose climber, Baron Mueller, when describing the plant in Fragm. iv. 144, had no fruit. The plants were in fruit in the Mulgrave River scrubs, so I may add to his description the following :- Fruit 3-winged, 3 -celled, measuring (including the wings) about 4 lines diameter, tomentose like the rest of the plant, wings veined; seeds glossy, light brown, a line long, showing about 3 blunt angles.

\section{Order AMPELIDEZE.}

VITIS, Linn.

V. oblonga, Benth.; Fl. Austr. i. 447. Native Grape. 1, 7.

V. nitens, $F$. v. $M$.; Fragm. ii. 73; Fl. Austr. i. 448. Native Grape. 1.

* The few plants marked with an asterisk, I obtained but poor specimens of, but Baron Mueller has kindly assistcd me in their determination. The descriptions in all cases, however, are my own. 
V. trifolia, Linn.; Spec. Pl. 293; Fl. Austr. i. 449. Native Grape. 1, 7 .

V. hypoglauca, $F . v . M$.; Pl. Vict. i. 94; Fl. Austr. i. 450. Native Grape. 1.

V. acetosa, F. v. M.; Pl. Vict. i. 94. Native Grape. ?.

LEEA, Linn.

I. sambucina, Willd.; Spec. Pl. i. 1177; Fl. Austr. i. 451. 1, 7.

\section{Order SAPINDACEZE.}

\section{DIPLOGLOTTIS, Hook.}

D. diphyllostegia, $F . v . M$. Tamarind. 7 .

\section{HARP ULLIA, Roxb.}

H. frutescens, n. $s p$. $1,2,3,7$. A slender usually singlestemmed shrub, so far as observed never attaining more than 5 feet, slightly rusty-pubescent. Leaf-rhachis prominently winged to the base, and extending beyond the last pinnæ; pinnæ nearly opposite, sessile, lanceolate, with attenuated points, 4 to 8 in. long, $1 \frac{1}{2}$ to $2 \frac{1}{2}$ in. wide in the centre, membranous, of a dark green and always quite entire. Inflorescence a terminal erect panicle with but a few short branches near the base, the female or hermaphrodite flowers near the base, the end or upper ones male, white and fragrant, on short pedicels; sepals imbricate, 4 or 5 , linear-obtuse, 3 or 4 lines long, rusty-tomentose; petals 4, lanceolate, 6 or 7 lines long, recurved; stamens 7 or 8 , nearly as long as the petals, surrounded by a ring of short, erect, obtuse glands; capsule 2 or 3 -celled, forming spreading lobes $1 \frac{1}{2}$ in. wide and $1 \mathrm{in}$. deep, the outside clothed with a deep crimson tomentum, 2 seeds in each cell, enveloped in a cup-shaped yellow arillus.

Hab.: Bellenden-Ker, at an altitude of over 2,000 feet, and very frequently met with in the scrubs bordering the rivers on the lower lands of the district. In Fragm. ix. 89, July, 1875, Baron von Mueller notices this plant as occurring at Rockingham Bay, as H. alata, F. v. M., having entire leaflets and flowering as a shrub. I have, however, during my recent visit to Bellenden-Ker, made a point of hunting for any plant of the species with serrated leaflets, or that attains the size of even a large shrub, and having failed, think it better to give this Northern plant specific rank.

H. Fillii, F. $v . M$. in Trans. Vict. Inst. iii. 26 ; Fl. Austr. i.470. 2.

H. pendula, Planch.; Fl. Austr. i. 471. Tulip-wood. 7.

\section{D0D0NFA, Linn.}

D. viscosa, Linn.; DC. Prod. i. 616 ; Fl. Austr. i. 475. Hopbush. 7.

\section{Order ANACARDIACEA.}

BLEPHAROCARYA, F. v. M.

B. involucrigera, F.v.M.; Fragm. xi. 16. 1. 
SEMECARPUS, Linn. $f$.

S. Anacardium, Linn.; W. and Arn. Prod. 168; Fl. Austr. i. 491. Marking Nut. 7.

\section{SPON DIAS, Linn.}

S. pleiogyna, F. $v$. $M$.; Fragm. iv. 78. Burdekin Plum; "Noongi" and "Rancooran" of the natives. 1.

\section{Order CONNARACEA.}

TRICOLOBUS, Blume.

T. connaroides, F. v. M. ; Fragm. viii. 224. 1, 2, 5.

\section{Order LEGUMINOSA.}

CROTALARIA, Linn.

C. juncea, Linn.; DC. Prod. ii. 125; Fl. Austr. ii. 179. Sunhemp. 7.

This plant is extensively cultivated in India for the sake of its fibre, which is known as the Madras hemp.

C. linifolia, Linn.f.; DC. Prod. ii. 128; Fl. Austr. ii. 180.7.

INDIGOFERA, Linn.

I. pratensis, F. v. M.; Rep. Burdek. Exped. 10 ; Fl. Austr. ii. 198. Indigo. 7.

TEPHROSIA, Pers.

T. juncea, $R . B r . ;$ Fl. Austr. ii. 208. 7.

IDESMODIUM, Desv.

D. reniforme, $D C$.; Prod. ii. 327 ; Fragm. xii. 1.

URARIA, Desv.

U. lagopoides, DC.; Prod. ii. 324; Fl. Austr. ii. 237. 7.

This little plant is used in Hindoo medicine, but seldom alone. It is supposed to have alterative, tonic, and anti-catarrhal properties.

GLYCINE, Linn.

G. clandestina, Wendl.; Bot. Beob. 54; Fl. Austr. ii. 243.7.

IIUCUNA, Adans.

TM. gigantea, DC. ; Prod. ii. 405; Fl. Austr. ii. 254. Black Bean. 7.

CANAVALIA, DC.

C. obtusifolia, DC.; Prod. ii. 404; Fl. Austr. ii. 256. Coast Bean. 7.

RHYNCHOSIA, Lour.

R. Cunninghamii, Benth.; Fl. Austr. ii. 266. Blue Bean or Pea. $1,7$. 


\section{FLEMINGIA, Roxb.}

F. lineata, Roxb.; DC. Prod. ii. 351 ; Fl. Austr. ii. 268.7.

F. involucrata, Benth. in Pl. Jungh. i. 246 ; Fl. Austr. ii. 269.7.

\section{DERRIS, Lour.}

D. koolgibberah, n. sp. (From "Koolgibberah," the aboriginal name for the Mulgrave River.) A woody climber attaining a considerable height, densely covered by soft ferruginous hairs, particularly on the branches and inflorescence. Leaflets usually 7 , broadly oblong, 3 to $5 \mathrm{in}$. long, 2 to $3 \mathrm{in}$. broad, rounded at the base to a petiolule of about 2 lines, very obtuse or slightly apiculate at the point, the terminal leaflet larger, the 6 or 8 primary veins on each side of the midrib and the cross-veins usually prominent, midrib and primary veins with rusty hairs on both sides, upper surface somewhat glossy, under surface with a pale soft pubescence. Inflorescence in narrow panicles 10 to $18 \mathrm{in}$. long, the side branches very numerous, about 3 in. long, the upper half densely corered by the flower; pedicels very short, bracteoles close under the calyx; flowers singly, not in pairs or clusters but very close together, slightly rosy; calyx campanulate, dark, velvety, with obscure teeth, $1 \frac{1}{2}$ lines deep; standard orbicular, with small inflexed auricles at the base on a very short claw, about 4 lines diameter, relvety on the back; wings slightly shorter and more or less adhering to and incurved with the keel, and densely velvety; upper stamen shortly free at the base, united with the other in the middle. Pod densely clothed with rusty brown hairs under 2 in. long and about $\frac{1}{2}$ in. wide, somewhat pointed at each end, prominently winged along the upper suture, 1-seeded, but only immature pods seen.

Hab.: Border of scrubs along the Mulgrave River. In some respects this Queensland plant approaches D. ferruginea, Benth.

\section{PONGAMIA, Vent.}

P. glabra, Vent.; Jard. Malm.t. 28; Fl. Austr. ii. 273. Pongatree of India. 1.

PODOPETALUM, F. v. M.

P. Ormondi, F.v.M.; Fragm. xii. ; Melb. Chem. and Drug., June, 1882. 1 .

CASTA NOSPERMUM, A. Cunn.

C. australe, A. Cunn. in Hook. Bot. Misc. i. 241 , t. 51,52 ; Fl. Austr. ii. 275. Bean-tree; native name "Kongo," of Russell River natives. $1,2$.

CASSIA, Linn.

C. mimosoides, Linn.; Vog. Syn. Cass. 68; Fl. Austr. ii. 291.1.

ENTADA, Adams.

E. scandens, Benth. in Hook. Jourl. Bot. iv. 332 ; Fl. Austr. ii. 298. Match-box Bean. 1, 7 .

\section{ADENANTHERA, Linn.}

A. pavonina, Linn.; Spec. Pl. 384; Fragm. v. 30. False Red Sandalwood. $1,7$. 


\section{ACACIA, Willd.}

A. flavescens, A. Cunn.; Benth. in Hook. Lond. Journ. i. 381 ; Fl. Austr. ii. 391. The Yellowish Wattle. 1, 2.

A. holosericea, A. Cunn. in G. Don. Gen. Syst. ii. 407; Fl. Austr. ii. 411. Silky Wattle. 7.

\section{PITHECOLOBIUM, Mart.}

P. pruinosum, Benth. in Lond. Journ. iii. 211; Fl. Austr. ii. 423. Monkey Pod. 7.

ARCHIDENDR0N, F. v. M.

A. Vaillantii, F. v.M.; Fragm. v. 60. 1, 7 .

\section{Order ROSACEA.}

RUBUS, Linn.

R. moluccanus, Linn.; DC. Prod. ii. 566 ; Fl. Austr. ii. 430. Blackberry. 5 .

R. rosæfolius, Sm.; Ic. Pl. t. 60; Fl. Austr. ii. 431. Raspberry. 1,2 .

This native Raspberry produces a very much superior fruit in the tropics, and full advantage was taken of the ripe fruit by our party.

\section{Order SAXIFRAGEA.}

ARGOPHYLLUM, Forst.

A. Iejourdanii, F. v. M. ; Fragm. iv. 33 ; Fl. Austr. ii. 437. 1, 7.

ABROPHYLLUM, Hook. f.

A. ornans, Hook. f.; Fl. Austr. ii. 437.

POLYOSMA, Blume.

P. alangiacea, F. v. M. ; Fragm. viii. 8. 5 .

DAVIDSONIA, F. v. M.

D. pruriens, F. $v . M$. ; Fragm. vi. 4. Davidson's Plum. 1, 2, 7. This is an excellent fruit and, being in good order for use, was very acceptable. The fruit is an oval drupe, very juicy, of rich purple colour, and sharp, pleasant, acid flavour; some gathered measured 3 in. long and $2 \mathrm{in}$. diameter.

WEINMANNIA, Linn.

W. Biagiana, F. v. M. ; Fragm. v. 16. 5 .

\section{Order HALORAGE王.}

MYRIOPHYLLUM, Linn.

II. verrucosum, Lindl. in Mitch. Trop. Austr. i. 384; Fl. Austr. ii. 488. Warted Water Milfoil. 7. 


\section{Order RHIZOPHOREAE.}

RHIZOPHORA, Linn.

R. mucronata, Lam.; DC. Prod. iii. 32; Fl. Austr. ii. 493. Mangrove. 5.

Mr. C. Hedley, F.L.S., tells us that the natives about Port Curtis consider the honey of the native bee to be poisonous when collected from near mangrove swamps.

CERIOPS, Arn.

C. Candolleana, Arn. in Ann. Nat. Hist. i. 364; Fl. Austr. ii. 494. The Kirrari of India. 5.

BRUGUIERA, Lam.

B. Rheedii, Blume; Enum. Pl. Jav.92 ; Fl. Austr. ii. 494. Red Mangrove. 5.

CARALEIA, Roxb.

C. integerrima, $D C . ;$ Prod. iii. 33 ; Fl. Austr. ii. 495 . The Kierpa-tree of India. 5.

\section{Order MYRTACEE.}

LEPTOSPERMUM, Forst.

I. wooroonooran, $n$. $s p$. (Aboriginal name for Bellenden-Ker.) Trunk often extending in an almost horizontal position for several yards at from 3 to 6 feet above the ground, 2 or 3 feet diameter, with a thick stringy bark, from which branches arise to 20 or $30 \mathrm{ft}$., thus forming a large spreading-headed tree of dense foliage. This peculiar growth is due probably to the high winds which blow at certain seasons of the year. Leaves alternate, lanceolate, $\frac{1}{2}$ to $\frac{3}{4}$ in. long, 2 to $2 \frac{1}{2}$ lines broad in the centre, midrib and a marginal nerve on each side prominent, oil-dots numerous, with blunt, glandular, slightly recurved apex, base decurrent forming angles on the branchlets, slightly silky when young, as are also the young shoots. No flowers seen. Capsules solitary or 2 together at the ends of the short branchlets; calyx-tube glabrous, 5-ribbed, corresponding with the 5 cells, nearly sessile, slightly over 2 lines diameter; the capsule prominent above the calyxtube.

Hab.: South Peak, Bellenden-Ker, and so far as at present known only found there. The wood is strong, heavy, and of a reddish colour.

I. scoparium, Forst.; Char. Gen. 48; Fl. Austr. iii. 105. Captain Cook's Tea-tree.

It was one of the several forms of this plant which was used by the seamen of Captain Cook's vessel for making tea, hence the name "Tea-tree" for this and several other Leptospermums, Melalencas, and allied shrubs, erroneonsly at times written "Ti-tree," a Maori name for a Cordyline.

CALLISTEMON, R. Rr.

C. lanceolatus, $D C$.; Prod. iii. 223; Fl. Austr. iii. 120 . Red Bottle-brush or "Marum." 7.

C. paludosus, F.v. M.; Fragm. i. 14. Swamp Bottle-brush. 1, 7. 


\section{MELALEUCA, Linn.}

M. leucadendron, var. saljgna, Fl. Austr. iii. 142. Paperbarked Tea-tree. 1,7 .

II. leucadendron, var. Cunninghamii, Fl. Austr. iii. 143. Both the red and yellow flowered kinds. 7.

\section{EUCALYPTUS, L'Hér.}

E. tereticornis, Sm.; Bot. Nov. Holl. 41, and in Trans. Linn. Soc. iii. 284; Fl. Austr. vii. 241. Blue Gum. 1, 7.

E. platyphylla, F. v. M. in Journ. Linn. Soc. iii. 93 ; Fl. Austr. iii. 242. Deciduous Gum. 7.

E. tesselaris, F.v. $M$. in Journ. Linn. Soc. iii. 88; Fl. Austr. iii. 251. "Wonkara," native name at Port Curtis ; Moreton Bay Ash. 1, 7.

E. corymbosa, Sm. ; Bot. Nov. Holl. 43, and in Trans. Linn. Soc. iii. 287 ; Fl. Austr. iii. 256. Bloodwood. 1, 7.

\section{TRISTANIA, R. Br.}

T. conferta, R. Br. in Ait. Hort. Kew. ed. 2, iv. 417; Fl. Austr. iii. 263. Brisbane Box. 1, 7 .

T. suaveolens, Sm. in Rees Cycl. xxxvi.; Fl. Austr. iii. 262. Swamp Mahogany. 1,7.

T. exiliflora, F. v. M. ; Fragm. v. 11 ; Fl. Austr. iii. 264. 1, 7.

XANTHOSTEMON, F. v. M.

X. chrysanthus, F. v. M.; Fl. Austr. iii. 268. 1, $2,7$.

\section{RHODOMYRTUS, DC.}

R. psidioides, Benth.; Fl. Austr. iii. 272. 1.

R. trineura, F. v. $M$. ; Fl. Austr. iii. 272. 4.

R. macrocarpa, Benth.; Fl. Austr. iii. 273. Cooktown Loquat. 1, 7. This furnishes an edible red juicy fruit.

\section{MYRTUS, Linn.}

II. racemulosa, Benth.; Fl. Austr. iii. 276. Black-fruited Myrtle. 2. A tall shrub or small tree, with ovate acuminate leaves all under 2 in. long. Fruit a black berry containing numerous seedsover 25 in the fruits examined; these are borne on solitary filiform peduncles above the axils of the leaves, but probably the subtending leaves were abortive and had fallen.

\section{MYRTUS?}

Tree 30 or 40 feet high, trunk often crooked, 1 to $1 \frac{1}{2}$ feet diameter, bark thick and loose on the outside; head spreading and foliage very dense; branchlets and leaf-petioles silky-hairy. Leaves ovate, with long acuminate points, mostly under 1 in. long, glabrous except while very young, coriaceous, the midrib alone showing, glossy on the upper, pale and closely dotted with minute dots on the under side; petioles 2 lines long.

This and the Leptospermum wooroonooran are the only two large trees on the south peak of Bellenden-Ker, therefore of sufficient interest to mention, although no flowers or fruit were obtained. I have placed it under Myrlus, but it strongly reminds one of some of the New Zealand Metrosideros. 
RHODAMNIA, Jack.

R. sessiliflora, Benth.; Fl. Austr. iii. 277. 1.

R. trinervia, Blume; Mus. Bot. i. 79 ; Fl. Austr. ii. 278. 1.

R. Blairiana, F. v. M. ; Fragm. ix. 141. 3, 4, and summit of Mount Sophia. At Palm Camp, 4,000 feet, this attains the height of 70 or 80 feet; has an erect trunk, with a loose almost fibrous bark.

\section{PSIDIU M, Linn.}

P. guava, Raddi; Hook. Fl. Ind. ii. 468; Syn. Queensl. Flora, 2nd Suppl. 26. Apple Guava. 5.

This well-known fruit is naturalised about Harrey's Creek.

EUGENIA, Linn.

G. grandis, Wight; Illustr. ii. 17, and Ic. t. 614; Fl. Austr. iii. 285. 6. The leaves of this Bartle Frere form are very much smaller than usual, also thicker; in stature the plant is also smaller, it only forming a large shrub; but only having unopened buds to determine by, I cannot give characteristics to distinguish it from other forms.

E. cormiflora, $F . v$. $M$. ; Fragm. v. 32; Fl. Austr. iii. 284. "Murro," native name of fruit. 2, 6 .

E. jambolana, Lam.; Dict. iii. 198; Fl. Austr. iii. 283.7.

F. Wilsonii, F. v. M. ; Fragm. v. 12; Fl. Austr. iii. 285. .3, 4, 5 .

E. oleosa, F. v. M. ; Fragm. v. 15 ; Fl. Austr. iii. 287. Blue-fruited Eugenia. 2. A large straggling shrub, with broadly lanceolate leaves 2 or $3 \mathrm{in}$. long. Flowers in trichotomous panicles, bearing 3 flowers at the end of each branch; calyx-lobes 4, minute; petals 4, slightly larger than the calyx-lobes, very fugitive; filaments $1 \mathrm{in.long,}$ capillary; anthers minute; style slightly exceeding the stamens. Fruit globular-oblong, $\frac{3}{4}$ in. long, and of a beautiful blue colour, maturing a solitary seed.

Hab.: Whelanian Pools.

BARRINGTONIA, Forst.

B. racemosa, Gaudich. in Freyc. Voy. Bot. 483, t. 107.1.

CAREYA, Roxb.

C. australis, F. v. M. ; Fragm. v. 183 ; Fl. Austr. iii. 289. Native names at various places- "Go-onja," "Guntha-marrah," and "Barror." 1.

\section{Order MELASTOMACEÆ.}

OTANTHHRA; Blume.

O. bracteata, Korth; Verh. Nat. Gesch. Bot. 235, t. 51 ; Fl. Austr. iii. 292. 5,7 .

MELASTOY A, Linn.

Mr. malabathricum, var. polyanthum, Fl. Austr. iii. 292. 1,7 . 


\section{Order PASSIFLOREE.}

CARICA, Linn.

C. Papaya, Linn.; Roxb. Ind. Flora, iii. 824. Papaw-tree. 5. This excellent fruit is becoming naturalised about Harrey's Creek.

\section{PASSIFLORA, Linn.}

P. quadrangularis, Linn.; Spec. Pl. 1356. The large Granadilla. 5,7 .

This well-known tropical American fruit is naturalised about Harvey's Creek and Mulgrave River.

P. fœtida, Linn.; Spec. Pl. 1359. Love-in-a-mist Passionflower. 7 .

Naturalised about Mulgrave River, where the fruit is eaten by children without any ill effects.

\section{Order CUCURBITACER.}

\section{TRICHOSANTHES, Linn.}

T. pentaphylla, F. v. M.; Fl. Austr. iii. 314. 7.

\section{LUFFA, Cav.}

I. ægyptiaca, Mill.; Dict.; Ser. in DC. Prod. iii. 303 ; Fl. Austr. iii. 316. Peramara. 7.

Bentham, in Fl. Austr. iii. 317, objects to Baron Mueller raising this form of Luffa agyptiaca to specific rank as $L$. leiocarpa, saying that the raised lines of the fruit are quite as conspicuous in the Autralian as in some Indian ones; but the intense bitter of even the dry fibres of the fruit-a feature also noticed by Mueller, Fragrn. iii. 107, 1862, but not recorded in Flora Austr. 1.c.-furnishes, I think, a good mark of distinction as a variety, hence the name here adopted. Dr. Thos. L. Bancroft bas, however, made an extract from the dried fruit, and we may therefore shortly hear something of its properties.

BRYONIA, Linn.

B. laciniosa, Linn. ; Ser. in DC. Prod. iii. 308 ; Fl. Austr. iii. 319. $1,2,5,7$.

MELOTHRIA, Linn.

IM. Cunninghamii, F. v. $M$. ; Fl. Austr. iii. 320. 5, 7 .

CUCUMIS, Linn.

C. trigonus, Roxb. ; Fl. Ind. iii. 722 ; Fl. A ustr. iii. 317. 7.

BENINCASA, Savi.

B. vacua, F. v. MI. ; Fragm. vi. 186.7 .

\section{Order UMBELLIFERE.}

HYDR0COTYLE, Linn.

H. asiatica, Linn.; DC. Prod. iv. 62; Fl. Austr. iii. 346. Asiatic Pennywort. 1.

H. hirta, R. Br, in A. Rich. Hydroc. 64; Fl. Austr. iii. 339. 7.

I. laxiflora, $D C$.; Prod. iv. 61 ; Fl. Austr. iii. 340. 7. 


\section{Order ARALIACEAE.}

ARALIA, Linn.

* A. Macdowalli, F. v. MI.; So. Sci. Rec. April, 1886. 2, 3, 5. To which description may be added:-Tree with slender erect trunk 30 to 40 feet high, the whole as well as the branches densely covered with short, stout, sharp prickles except on the petioles, although present there. No flowers or fruit on the trees met with.

POROSPERMUM, F. v. M.

P. Michieanum, F. v. M. ; Fragm. vii. 95. 5.

MACKINLAYA, F. v. M.

II. macrosciadum, F.v. IM.; Fragm. iv. $120.1,2,5$.

ASTROTRICHA, DC.

A. pterocarpa, Benth.; Fl. Austr. iii. 379. 7, and Walsh's Pyramid.

PANAX, Linn.

P. Murrayi, F.v.M.; Fragm. ii. 106. 1, 7.

P. elegans, $F$. $v$. $M$. in Trans. Phil. Inst. Vict. ii. 68; Fl. Austr. iii. 383. Mowbulan Whitewood, or of the natives "Greyanger." $1,5,7$.

Pentapanax, Seem.

P. Willmotti, F.v. M. ; Austr. Journ. of Pharm. 1887. 6.

BRASSAIA, Endl.

B. actinophylla, Endl.; Nov. Stirp. Dec. 89 ; Fl. Austr. 385. Umbrella-tree. $1,2$.

HEDERA, Linn.

H. australiana, F. v.M.; Fragm. iv. 120. 5.

\section{Order RUBIACE}

SARCOCEPHALUS, Afz.

S. cordatus, Miq.; Fl. Ind. Bot. ii. 133; Fl. Austr. iii. 402. Leichhardt-tree. 1,7 .

\section{UNCARIA.}

U. ferrea, $D C$.; Prod. iv. 348; Hook. Ind. Flora, iii. 33. 7. Now met with for the first time in A ustralia, but known from Sumatra, Java, and Borneo. A tall rusty-hairy climbing plant, furnished with hooked tendrils; the Queensland plant has rather large capsules $\frac{1}{3}$ in. or even more long.

From some leaves which I submitted to Dr. Thos. L. Bancroft for examination, lhe states that he found them to contain catechu, like $U$. Gambier, another Indian species, from the foliage of which the catechu of commerce is obtained. An interesting genus on account of one, $U$. Gambier, furnishing from its leaves the astringent extract called "Gambier" or "Terra Japonica."

\section{HEDYOTUS, Linn.}

H. auricularia, Linn.; DC. Prod. iv. 420; Fl. Austr. iii. 404. 5.

H. cærulescens, F. v. MI. ; Fragm. iv. 38; Fl. Austr. iii. 404. 7. 
DENTELIA, Forst.

D. repens, Forst.; DC. Prod. iv. 419; Fl. Austr. iii. 404.7.

WEBERA, Schreb.

W. Dallachiana, F.v. M.; Fl. Austr. iii. 412. 1, $2,7$.

\section{RANDIA, Linn.}

R. hirta, F. v. M. ; Fragm. vii. 46. 1, 2.

I. Fitzalani, F.v. M. ; Fl. Austr. iii. 411. 1.

GUETTARDA, Linn.

* G. tenuiflora, F. v. M. ; Fl. Austr. ii. 413. 5.

TIHONIUS, Rumph.

T. Rumphii, DC. ; Prod. iv. 461; Fl. Austr. iii. 417. 1, 7.

KNOXIA, Linn.

IR. corymbosa, Willd.; W. and Arn. Prod. i. 439; Fl. Austr. iii. 438. 1,7 .

\section{IXORA, Linn.}

I. timorensis, Done.; Herb. Tim. Descr. 90 ; Fl. Austr. iij. 415. 1,7 .

PAVETTA, Linn.

P. indica, Linn.; W. and Arn. Prod. 431; Wight Ic. t. 148; Fl. Austr. iii. 414. 7. Called "Pavetti" in part of India.

MORINDA, Linn.

M. citrifolia, Linn.; DC. Prod. iv. 446 ; Fl. Austr. iii. 423. 1,7 .

II. hypotephra, F.v. M.; Vict. Nat. vol. vi. No. 3, p. 55. 4.

CELOSPER MUM, Blume.

C. reticulatum, Benth.; Fl. Austr. iii. 427. 7.

GEOPHLLA, Don.

G. reniformis, D. Don.; Prod. Fl. Nepal; Syn. Queensl. Fl. 240. Ground Cherry. 1, 2, 7.

PSYCHOTRLA, Linn.

P. Ioniceroides, Sieb. in DC. Prod. iv. 523; Fl. Austr. iii. 427. 7. P. Dallachiana, Benth.; Fl. Austr. iii. 427. 1, 2, 3.

LASIANTHUS, Jack.

T. strigosus, Wight in Cala. Journ. Nat. Hist. vi. 512 ; Fl. Austr. iii. $426.1,2$.

\section{IIYDNOPHYTUM, Jack.}

F. formicarum, Jack. in Trans. Linn. Soc. xiv. 124 ; Syn. Queensl. Fl. 231. Ant-house plant. 1.

A most curious gouty-stemmed epiphytc. 


\section{Order COMPOSIT 尼.}

ADENOSTEMMA, Forst.

A. viscosum, Forst.; Char. Gen. 89, t. 45 ; Fl. Austr. iii. 462. 2.

AGKRITUM, Linn.

A. conyzoides, Linn.; DC. Prod. v. 108 ; Fl. Austr. iii. 462. Billygoat-weed. 5, 7 .

Although a soft plant it has become a great nuisance, both in field and cultivation.

LAGENOPHORA, Cass.

I. Billardieri, Cass.; DC. Prod. v 307 ; Fl. Austr. iii. 507. 1, 7.

ERIGERON, Linn.

E. linifolia, Willd.; Spec. Pl. Fl. Austr. iii. 495. Cobbler's. pegs. 7.

\section{PTEROCAULON, Ell.}

P. cylindrostachys, Clarke; Gen. Pl. Fl. Austr. iii. 523; Syn. Queensl. Fl. 248. 7.

P. sphacelatus, Benth. et Hook.; Fl. Austr. iii. 523; Syn. Queensl. Fl. 248. 7.

\section{HELICHRYSUM, Vaill.}

H. elatum, A. Cunn. in DC. Prod. vi. 193; Fl. Austr. iii. 621. 2,3.

SIEGESBECKIA, Linn.

S. orientalis, Linn.; DC. Prod. v. 495 ; Fl. Austr. iii, 535.1.

\section{BIDENS, Linn.}

B. pilosa, Linn.; DC. Prod. v. 597 ; Fl. Austr. iii. 543. Cobbler's-pegs. 1.

GLOSSOGYNE, Cass.

G. tenuifolia, Cass.; DC. Prod. v. 632 ; Fl. Austr. iii. 544. 7.

CENTIPEDA, Lour.

C. Orbicularis, Lour.; Fl. Cochin ii. 492 ; Fl. Austr. iii. 553. Snuff-weed. 7.

CREPIS, Linn.

C. japonica, Benth. ; Fl. Hongk.; Fl. Austr. iii. (779. 1, 7.

SONCHUS, Linn.

S. oleraceus, Linn.; Spec. Pl. 1116; Fl. Austr. iii. 679. Sowthistle. 7.

\section{Order STYLIDIEAE.}

STYLIDIUM, Swartz.

S. alsinoides, R.Br.; Prod.; Fl. Austr. iv. 24.7.

S. uliginosum, $\$$ w. ; DC. Prod. vii. 336 ; Fl. Austr. iv. 26.7. 


\section{Order GOODENOVIEAE.}

\section{SCEVOLA, Linn.}

S. scandens, n. sp. (Referring to the climbing habit of plant.) A large climbing plant rambling over the surrounding shrubs to the height of 10 or $12 \mathrm{ft}$. Leaves opposite, bordered with sharp, distant, small teeth, ovate, 3 or 4 in. long with narrow elongated apex and short petiole. Flowers solitary, or 2 or 3 on a short peduncle; calyx-tube about 2 lines long, with minute teeth; corolla $\frac{3}{4}$ in. long, split open on one side to the base, the inside lined with woolly hairs, the outside glabrous and purplish, except the wavy edges which are bright-yellow; stamens scarcely exceeding the corolla-tube in length; style narrowly winged, shortly incurved at the top; indusium hairy on the back, besides the dense ring of silky-white hairs surrounding the cup. Fruit not seen.

Hab. : Bellenden-Ker, at about 3,000 ft.

\section{Order CAMPANULACEE.}

LOBELIA, Linn.

I. humistrata, F.v.M.; Fl. Austr. iv. 130. 7.

\section{WAHLENBE ïGIA, Schrad.}

W. gracilis, $A$. DO. ; Monogr. Camp, 142; Prod. vii. 433; Fl. Austr. iv. 137. Bluebell. 1.

\section{Order VACCINIACE正.}

AGAPETES, D. Don.

A. Meiniana, F.v.M.; Vict. Nat. 1887. 6.

\section{Order ERICACEAE.}

RHODODENDRON, Linn.

R. Iochæ, F.v.M.; Vict. Nat. 1887. 4.

\section{Order EPACRIDE $A$.}

TROCHOCARPA, R. Br.

T. laurina, $R$. Br. ; Prod. 548; Fl. Austr. iv. $166.4,6$.

This is one of the most common shrubs met with on the summit of Bellenden. Ker and Bartle Frere.

LEUCOPOGON, R. Br.

I. pluriloculatus, F.v.M.; Fragm. i. 37 ; Fl. Austr. iv. 207. 2.

MONOTOCA, R. Br.

IM. lineata, R. Br. ; Prod. 547 ; Fl. Austr. iv. 230.6.

J. J. Labillardiére, in Pl. Nov. Holl. i. 45, is the only one to notice that the fruit of this small tree has 5 cells, which I found to be the case in the specimen I examined from Bartle Frere. I think this is the first time the plant has been found out of Tasmania. The fruit of our plant is roundish, about 2 lines in diameter, and of a rich red colour. It is strange that neither Dr. Hooker in the Tasmanian 
Flora, nor Mr. Bentham in the Flora Australiensis, gives the number of cells in the fruit ; and both refer to Labillardiére's description and figure in which the 5 cells are mentioned and shown under his name of Styphelia glauca. It is probable that in the typical specimen received by Robt. Brown the fruit was 1-celled by abortion, as stated to be sometimes the case by Labillardiére.

\section{DRACOPHYLLUB, Labill.}

D. Sayeri, Fr.v.M.; Austr. Journ. of Pharm. 1887. 4, 6. The following may be added to the description given by Baron von Mueller, in the Australasian Journal of Pharmacy, March, 1887. Trunk attaining a diameter of $10 \mathrm{in}$; bracts 3 in. long, white, shaded with deep rose. There are probably two varieties of this species, which may be distinguished by the flowers of the one having a white tube and horizontal rose-coloured lobes, which seem to become somewhat erect in decay. Of the other the flowers are all white, and the corolla-Jobes are closely reflexed, and remain so in decay. I found this distinction on all the plants examined, even when growing beside each other.

\section{Order MYRSINE 2 .}

MYRSINE, Linn.

IM. variabilis, $R$. Br. ; Prod. 543 ; Fl. Austr. iv. 275.7.

ARDISIA, Linn.

A. pseudojambosa, F. v. M. ; Fragm. iv. 81 ; Fl. Austr. 276.

EGICERAS, Gærtn.

Æ. majus, Gartn.; A. DC. Prod. viii. 142 ; Fl. Austr. iv. 277. River Mangrove. 5.

\section{Order OLEACEA.}

JASMINUM, Linn.

J. didymum, Forst.; Prod. 3 ; Fl. Austr. iv. 294. Jasmine. 1.

LINOCIERA, Swartz.

I. ramiflora, DC.; DC. Prod. viii. 297 ; Fl. Austr. iv. 301. 1.

\section{Order APOCYNACEE.}

CARISSA, Linn.

C. Ovata, $R . B r$. ; Prod. 468 ; Fl. Austr. iv. 305.1.

ALYXIA, R. Br.

A. ruscifolia, R. Br.; Prod. 470 ; Fl. Austr. iv. 308. 2, 3, 4 . This was very abundant on the mountain tops.

A. ilicifolia, F.v.M.; Fragm.iv. 149, v. 212 ; Fl. Austr.iv. 308. 3. A. spicata, $R$. Br.; Prod. 470 ; Fl. Austr. iv. 308. 1, $2,7$.

\section{CERBERA, Linn.}

A. Odollam, Gartn.; A. DC. Prod. viii. 353 ; Fl. Austr. iv. 306. The "Dabur" of Bengal. 5.

The seeds of this tree are said to contain crystalline poisonous glucoside. Vide Dr. W. Dymock, Veg. Mat. Med. of Western India, for this and most other notices on the medicinal properties of the plants noticed. 
ALSTONIA, R. Br.

A. scholaris, R. Br.; A. DC. Prod. viii. 408 ; Fl. Austr. iv. 312. $1,2,7$. In this district the wood often called Pine.

A. villosa, Blume; F. v.M. Fragm. vi. 117 ; Fl. Austr.iv. 313. 1.

A. verticillosa, F. v. M. ; Fragm. vi. 116; Fl. Austr. iv. 313. 7.

TABERNAMONTANA, Linn.

T. orientalis, $R$. Br. ; Prod. 463; Fl. Austr. iv. 311. $1,7$.

\section{Order ASCLEPIADERE.}

HOYA, R. Br.

F. carnosa, R. Br. ; Dene. in DC. Prod. viii. 636 ; Fl. Austr. iv. 346. Waxflower or Honeyflower. 1.

H. australis, $R$. $B r$.; Traill in Trans. Hort. Soc. vii. 28; Fl. Austr. iv. 346. 1, 2, 7.

H. Nicholsoniæ, F.v.MI.; Fragm. จ. 159 ; Fl. Austr. iv. 347. $1,2$.

I. Keysii, Bail. ; Proc. Roy. Soc., Queensl. 2. Francesca Falls.

DHSCHIDIA, R. Br.

D. nummularia, R. Br.; Prod. 461; Fl. Austr. iv. 345. Button Orchid. 1, 7 .

I find this generally known by the above, but it is unfortunate, as it is in nowise related to the Orchids.

\section{Order LOGANIACEZE.}

MITRASACHE, Labill.

M. polymorpha, R. Br. ; Prod.; Fl. Austr. iv. 353. 6.

II. indica, Wight ; Ic. t. 1601 ; Fl. Austr. iv. $356.1,7$.

II. pygmza, R. Br.; Prod. 543 ; Fl. Austr. iv. 357. 1, 7.

FAGRTA, Thunb.

*F. racemosa, ? Jack. 1,2. This Baron Mueller thinks may belong to the Indian tree. It, however, differs from all species of which I have descriptions, but not having seen flowers I fully agree with him that it would be inadvisable to give it a distinctive name. It forms a small tree, say 30 feet high, with wide-spreading head with the leaves clustered at the ends of the branches. Leaves lanceolate to oblong, much tapering towards the base, 6 to 9 or more inches long, coriaceous, on petioles of $1 \mathrm{in}$. Fruit in terminal short racemes or panicles, nearly globose, over 1 in. diameter, bright crimson outside, white within, containing numerous seeds.

\section{STRYCHNOS, Linn.}

S. Bancroftiana, $n$. $s p$. Snakewood. (After Dr. Joseph Bancroft, who has done so much to make known the medicinal properties of our indigenous plants.) Stems climbing, terete, often reaching the height of 40 or 50 feet, diameter of lower part $2 \mathrm{in.}$ In the upper portion, especially near the inflorescence, furnished with 
curved tendrils, which are curved like rams' horns, sometimes in pairs. Leaves opposite, glabrous, ovate-acuminate, 4 to 7 in. long, $1 \frac{1}{2}$ to 3 in. broad, triplinerved with often another lower pair forming an intramarginal nerve, and prominently reticulated; texture thin, cartilaginous, petioles scarcely $\frac{1}{2}$ in. long. Inflorescence axillary, racemose, or in racemose panicles 3 or 4 in. long. Flowers not seen. The persistent calyx under the fruit of 5 blunt lobes about a line long and broad. Fruit a globular brown berry, $\frac{1}{2}$ to 1 in. diameter, bearing the erect style; seeds flat, orbicular, from 1 to 4 in a fruit embedded in a mealy pulp.

Hab. : Tringilburra Creek and Mulgrave River.

I gave a few seeds of this plant to Dr. Thos. L. Bancroft for examination for active properties, and the following is his note:- "The seeds of the new Strychnos, like those of the other two Queensland species, are bitter; but they do not contain strychnine or, indeed, any poisonous substance-not at any rate in sufficient quantity, when in the form of an extract, to kill frogs."

\section{Order GENTIANERE.}

LRYTHRAA, Pers.

E. australis, R. Br.; Prod.; Fl. Austr. iv. 371. 1.

CANSCORA, Lam.

C. diffusa, R. Br.; Griseb. in DC. Prod. ix. 64; Fl. Austr. iv. 372. 5 .

\section{Order BORAGINEAE.}

CORIDA, Linn,

C. Myxa, Linn.; DC. Prod. ix. 479; Fl. Austr. iv. 386. Sapistan-tree. 7 .

C. aspera, Forst.; Prod. 18 ; Fl. Austr. iv. 386. 7.

TOURNEFOR'IIA, Linn.

T. sarmentosa, Lam.; Illustr. i. 416 ; Fl. A ustr. iv. $390 . \quad 1,7$.

\section{Order CONVOLVULACE开.}

IPOMCA, Linn.

I. angustifolia, Jacq.; Collect. ii. 367, and Ic. Rav. t. 317, not of Choisy ; Fl. Austr. iv. 425. 7.

LEPISTEMI ON, Blume.

L. urceolatus, F. v.MI.; Fragm. x. 111. 1, 7.

EVOLVULUS, Linn.

E. alsinoides, Linn.; Chois. in DC. Prod. ix. 447 ; Fl. Austr. iv. 437. 1,7 .

\section{Order SOLANACEE.}

LYCOPERSICUM, Mill.

I. esculentum, Miill.; Syn. Queensl. Flora, 342. Tomato. 5. $\Lambda$ stray from cultivation. 
SOLANUM, Linn.

S. nigrum, Linn.; Sp. Pl. 266; Fl. Austr. iv. 446. Black Nightshade. 5, 7.

S. verbascifolium, Ait.; Dun. in DC. Prod. xiii. part i. 114; Fl. Austr. iv. 449.7.

S. Dallachii, Benth.; Fl. Austr. iv. 456. 1, 2, 5, 7.

CAPSICUM, Linn.

C. frutescens, Linn.; Syn. Queensl. Flora, 348. Red Pepper. A stray from cultivation.

NICOTIANA, Linn.

N. Tabacum, Linn.; Syn. Queensl. Flora, 350. Tobacco. 7. A stray from cultivation.

\section{Order SCROPHULARINEÆE.}

VANDELLIA, Linn.

V. crustacea, Benth.; Scroph. Ind. and in DC. Prod.x. 413 ; Fl. Austr. iv. 496. 7 .

BUCHNERA, Linn.

B. linearis, R. Br.; Prod. 437 ; Fl. Austr. iv. 515. 7.

\section{Order LENTIBULARIEAE.}

UTRICULARIA, Linn.

U. exoleta, $R$. Br.; Prod. 430 ; Fi. Austr. iv. 526. Water Bladderwort. 5,7 .

\section{Order BIGNONIACE无.}

IIAUSMANNIA, F. v. M.

H. jucunda, F. v. M.; Fragm. iv. 148; Fl. Austr. iv. 540. 2, 5, 7 .

DIPLANTHERA, R. Br.

D. tetraphylla, R. Br.; Prod. 449; Fl. Austr. iv. 540. 1, 2, 7.

\section{Order ACANTHACEZE.}

RUELLIA, Linn.

R. australis, R. Br.; Prod. 479 ; Fl. Austr. iv. 547. 7.

ACANTHUS, Linn.

A. ilicifolius, Linn.; T. Anders. in Journ. Linn. Soc. ix. 501 ; Fl. Austr. iv. 54.8. Holly-leaved Bear's Breech. 5.

ERANTHEMUM, Linn.

E. variabile, $R$. Br. ; Prod. 477 ; Fl. Austr. iv. $555 . \quad 1,5,7$. 


\section{Order VERBENACEAE.}

CALLICARPA, Linn.

C. longifolia, Lam.; ex Schau. in DC. Prod. xi. 645; Fl. Austr. v. $57.1,2$.

VI'LXX, Linn.

V. acuminata, R. Br.; Prod. 512; Fl. Austr. v. 67. 7.

FARADAYA, F. v. M.

F. splendida, F. v. MI. ; Fragm. v. 21,212; Fl. Austr.v. 69. 1, 7.

CLERODENDRON, Linn.

C. Tracyanum, F.v. MI. ; Fl. Austr. v. 62. 5.

\section{Order LABIAT AE.}

\section{PLECTRANTHUS, L'Hér.}

P. parviflorus, Willd.; Benth. in DC. Prod. xii. 67, not of R. Br.; Fl. Austr. v. 78. 1.

P. Iongicornus, F. v. II. ; Fragm. v. 51; Fl. Austr. v. 77. 7.

COLEUS, Lour.

C. scutellarioides; Benth.; DC. Prod. xii. 73; Fl. Austr. v. 79. 5.

ANISONELES, R. Br.

A. Salvifolia, $R$. Br.; Prod. 503; Fl. Austr. v. 89.

AJUGA, Linn.

A. anstralis, R. Br.; Prod. 503; Fl. Austr. v. $136 . \quad$ Australian Bugle.

\section{Order NYCTAGINEAE.}

BOERHAAVIA, Linn.

B. diffusa, Linn.; Chois. in DC. Prod. xiii. ii. 452 ; Fl. Austr. v. 277. Spreading Hogweed. 7 . .

This common weed has lately been highly spoken of by medical men in India as a remedy in dropsical cases.

PISONIA, hinn.

P. Brunoniana, Endl.; Prod. Fl. Norf. 43, but not of Chois.; Fl. Austr. v. 280. 1, 7 .

P. aculeata, Linn.; Chois. in DC. Prod. xiii. ii. 440 ; Fl. Austr. v. 279.7 .

\section{Order AMARANTACERE.}

DEERINGIA, R. Br.

D. altissima, F.v. MI. ; Fragm. ii. 92, vi. 251 ; Fl. Austr. v. 210. 1,7 . 
CYATHULA, Lour.

* C. prostrata, Blume; Bijd. 549 ; Fl. Brit. Ind. iv. 723.7. (Achyranthes prostrata, Linn.)

A wide-spread tropical weed not previously met with in Australia.

\section{ACHYRANTHES, Linn.}

A. aspera, Linn.; Moq. in DC. Prod. xiii. ii. 314; Fl. A ustr. v. 246. Chirchira of India. 1, 5, 7 .

This is a rather troublesome weed on scrub land, but on the rich scrub land at Harvey's Creek I noticed it far more luxuriant than at any other place. However, from Dr. Dymock we learn that in India it is considered of some medicinal value. He tells us that it is called in Sanskrit A pámálga, or the Washerman, on account of the large quantity of alkali contained in its ashes, which are used in the preparation of alkaline medicines and caustic pastes. In Western India the juice is applied to relieve toothache. The ashes with honey are given to relieve cough, and European practitioners in India have established its value as a diuretic. It is plcasant to find so troublesome a weed has some redeeming qualities.

\section{Order CHENOPODIACER.}

CHENOPODIUM, Linn.

C. ambrosioides, Linn.; Moq. in DC. Prod. xiii. ii. 72 ; Fl. Austr. v. 162. 7.

C. carinatum, R. Br.; Prod. 407 ; Fl. Austr. v. 162.7.

\section{Order POLYGONACEZ.}

POLYGONUII, Linn.

P. strigosum, R. Br.; Prod. 420 ; Fl. Austr. v. 268. 7.

P. subsessile, R. Br. ; Prod. 419 ; Wl. Austr. v. 269.7.

P. attenuatum, R. Br.; Prod. 420 ; Fl. Austr. v. 272.7.

MUEHLENBECIIA, Meissn.

MI. gracillima, Meissn. in DC. Prod. xiv. 145 ; Fl. Austr. v. 274. 7.

\section{Order ARISTOLOCHIACEAE.}

\section{ARISTOLOCHIA, Linn.}

A. deltantha, F. v. MI. ; Fragm. vi. 179. Birthwort. Hills off Mulgrave River.

\section{Order PIPEPACEZE.}

PIPLIR, Linn.

P. subpeltatum, Willd.; Cass. DC. Prod. xvi. i. 333 ; Fl. Austr. vi. 204. Shrubby Pepper. 1, 2, 5.

P. novæ-hollandiz, Miq.; Pip. Nov. Holl. 8; Fl. Austr. vi. 204. 2 .

P. Banksii, Miq. ; Pip. Nov. Holl. 9 ; Fl. Austr. vi. 205.5. 
P. (Chavica) IMestoni, n. sp. Queensland Long Pepper. A large climber adhering to the stems of trees by adventitious roots. Leaves broadly ovate-acuminate, rounded at the base, and nearly or quite equal-sided, 6 to $8 \mathrm{in}$. long, 4 to $5 \mathrm{in}$. broad, on petioles of about $\frac{3}{4}$ in., septuplinerved. Spikes unisexual, leaf-opposed; males not seen; female or fruiting spikes of a brownish colour, formed by the firmly united fruits, nearly $2 \mathrm{in}$. long and 5 lines diameter at the base, terete, tapering towards the end; peduncles about $\frac{3}{4}$ in. long; styles rather prominent, 2-lipped.

Hab.: Harrey's Creek, Russell River.

This new species is nearly allied to $P$. Chaba, Hunter, Fl. Brit. Ind. v. 83 (the Chavica peepuloides, Miq., of Wight Ic. t. 1927).

It is worthy of remark that the present plant is nearly allied to the Long Pepper of commerce.

PEPEROMIA, Ruiz et Pav.

P. leptostachya, Hook. et Arn.; Bot. Beech. 96 ; Fl. Austr. vi. 206.1 . 1.

P. reflexa, A. Dietr.; Cass. DC. Prod. xvi. i. 451; Fl. Austr. vi. 206. 6. The form of this species found growing upon the rocks on the summit of Bartle Frere has more cuneate leaves than our ordinary one; they are about $\frac{1}{2}$ in. long, and distinctly petiolate, with a prominent midrib; spikes very slender, about $1 \mathrm{in}$. long.

\section{Order MYRISTICEA.}

MYRISTICA, Linn.

IM. insipida, $R$. Br.; Prod. 400 ; Fl. Austr.v. 281. Nutmeg. 7.

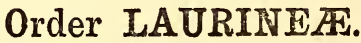

CRYPTOCARYA, R. Br.

C. australis, Benth.; Fl. Austr. v. 299. Queensland Curarabark. 7.

C. Mackinnoniana, $F . v$. $I I$. ; Fragm. v. 169 ; Fl. Austr. v. 296. 1.

C. triplinervis, R. Br.; Prod. 402; Fl. Austr. v. 297.1.

This and $C$. australis Dr. T. L. Bancroft has found to contain in their barks curarine, an active poisonous drug.

ENDIANDRA, R. Br.

E. discolor, Benth.; Fl. Austr. v. 301. 1.

LITSEA, Juss.

I. dealbata, var. rufa, Nees. Syst. Laurin. 630; Fl. Austr. v. $307.1,5,7$.

CASSY'THA, Linn.

C. pubescens, $R$. Br.; Prod. 404; Fl. A.ustr. v. 310 . Laurel Dodder. 2. 


\section{Order PROTEACEÆ.}

\section{PERS00NIA, Sm}

P. falcata, $R$. Br. in Trans. Linn. Soc. x. 162; Prod. 373; Fl. Austr. v. 385. Boomerang-leaved Geebung. 1.

\section{CYANOCARPUS, n. gen.}

\section{(So named from its bright-blue fruits.)}

Flowers hermaphrodite; perianth regular, in a straight tube before expansion; segments valvate, recurved when expanded; anthers on short filaments. Hypogynous glands 4, distinct, orbicular-ovate, equal. Ovary sessile, with long straight style; stigma terminal, clavate. Fruit a drupe with succulent juicy exocarp and cartilaginous endocarp, 1-seeded. A slender evergreen tree with alternate serrated leaves. Flowers in axillary racemes, pedicels comnate in pairs. Fruit a juicy bright-blue drupe.

C. Wortoniana, $n . s p$. (After the Hon. A. Norton, who has always taken a deep interest in Australian botany.) A small tree, the branches when young clothed with dark-reddish short hairs. Leaves alternate, broadly lanceolate or ovate-lanceolate, 4 to 7 in. long, 1 to 3 in. broad, irregularly but sharply serrate, the apex more or less elongated; petioles short, which with the primary veins are clothed with rusty hairs like the branchlets; texture membranous, upper surface glossy; primary veins prominent, joining some distance within the margin. Racemes axillary, 2 to 4 in. long, ferruginous; flowers in pairs, the pedicels short, connate, straight and slender in the bud, about 3 lines long, the segments closely revolute when expanded, glabrous inside; filaments equal in length with the anther, incurved; style erect, glabrous; stigma clavate; ovary sessile, very hairy. Fruit a bright-blue oval juicy drupe, about $\frac{1}{2}$ in. long, more or less hairy, and bearing the persistent, slender, straight style.

Hab.: Tringilburra Creek and creeks off Russell River.

A lovely tree when in full fruit; wood red, with the peculiar grain of the order.

\section{HILICIA, Lour.}

H. præalta, F. v. M. ; Fragm. iii. 37 ; Fl. Austr. v. 404. 1, 2.

H. Youngiana, F. v. $M I$.; Fragm. iv. 84; Fl. Austr. v. 406. 3.

H. ferruginea, F. v. M.; Fragm. iii. 37 ; Fl. Austr. จ. 405. 2.

I. Whelani, n. $s p$. 1. (After Sergeant E. J. Whelan). A glabrous tree of medium size. Trunk erect, bark smoothish, not thick, seldom more than $\frac{1}{2}$ in. on old trees; the branches opposite or whorled, reddish when young; wood with the usual grain of the order and deep red. Leaves opposite or more frequently at the ends of the branches in whorls of 3 to 6 , petiolate, lanceolate, 4 to $7 \mathrm{in}$. long, 1 to $3 \mathrm{in}$. broad, the points more or less elongated, midrib prominent; reticulations close, prominent in the dried leaf but scarcely so when fresh, margins entire. Flowers in terminal racemes of about 2 in. long, judging from the fruit specimens, but no flowers seen. Fruit indehiscent or slightly opening along the ventral suture, slightly ferruginous, globular, 2 or more inches in diameter, over $2 \frac{1}{2}$ in. when 
containing twin nuts; putamen globular when solitary, hemispherical when 2 in a fruit, of a light-brown, glossy and hard; testa dark-brown and wrinkled like the kernel.

Hab. : Abundant along Tringilburra Creek, and thence to Whelanian Pools.

The nuts seem to be largely used by the natives of this locality for food, as we found large quantities of the broken shells as well as the whole nuts at all their camps.

ORITES, R. Br.

O. fragrans, n. sp. 4. (Name referring to the fragrant flowers.) A tall shrub or small tree with dense spreading head, glabrous except the inflorescence and a slight hoariness on the young growth; the twigs or branches bearing the flowers, purplish or reddish. Leaves alternate, ovate-obtuse, emarginate or somewhat pointed, $2 \frac{1}{2}$ to $3 \frac{1}{2}$ in. long, and 1 to $2 \mathrm{in}$. broad; the margins quite entire, pale on the under surface; texture thin coriaceous, on slender coloured petioles of about $1 \mathrm{in.}$ Spikes numerous in the upper axils, about 2 or $3 \mathrm{in}$. long; at an early stage closely covered with broadly ovate, apiculate, prominently striated, imbricate, fugacious bracts, of a bright crimson colour; rhachis densely ferruginous pubescent; perianth 3 or 4 lines long, segments much recurved in the expanded flower; filaments broad, attached to the middle of the segment; anther about as long as the filament; ovary purple and silky, but less so than the style, which is very hairy and as long as the perianth.

Hab. : The highest peaks of Bellenden-Ker and also Bartle Frere.

A most attractive plant from the rich colour and fragrance of the inflorescence.

\section{HICESBEACHIA, F. v. M.}

M. pinnatifolia, F. v. M. ; South. Sci. Rec. 1883 ; Syn. Queensl. Flora, 810. Hills off the Mulgrave Kiver.

IOLIANDIEA, T. v. M.

H. Sayeri, F. v. MI.; Chem. and Drugg. of Austr.; 1887. 5. This is a very handsome tree of medium size, with large ovate-obtuse minutely toothed leaves, and long racemes of purplish-red flowers usually springing from the branches below the foliage. A most desirable tree for garden culture, but no fruit was obtainable.

GREVILLEA, R. Br.

G. polystachya, R. Br. in Trans. Linn. Soc. x. 177, Prod. 380; Fl. Âustr. v. 459.7.

G. gibloosa, $R$. Br. in Trans. Linn. Soc. x. 177, Prod. 380; Fl. Austr. v. 463. Round-fruited Beefwood. 7.

CARNARUONIA, F. v. M.

C. araliæfolia, F. v. M. ; Tragm. vi. 81, t. 55-56; Flora Austr. v. 410.2.

CAIDDWELLIA, F. v. M.

C. sublimis, $F \cdot v \cdot M I$; Fragm. v. 24. 1, 5 .

PANISI, Linn. f.

B. collina, $R$. $B r$. in Trans. Linn. Soc. x. 204, Prod. 394; Fl. Austr. v. 548. Walsh's Pyramid, Mulgrave River. 


\section{Order ELAEAGNACE正. \\ ELIEAGNUS, Linn.}

E. latifolia, Linn.; Schlecht. in DC. Prod. xiv. 610, and in Linnæa xxx. 347 ; Fl. Austr. vi. 39. 1, 5, 7.

\section{Order LORANTHACE丑.}

\section{LORANTHUS, Linn.}

I. longiflorus, Desr. in Lam. Dict. iv. 598 ; Fl. Austr. iii. 390. $2,3$.

I. alyxifolius, $F$. v. $M I$.; Fl. Austr. iii. 391. 4, 6.

I. exccarpi, Behr. in Linnæa xx. 624; Fl. Austr. iii. 392. 1.

\section{VISCUM, Linn.}

V. angulatum, Heyne; W. in Arn. Prod. 380; Fl. Austr. iii. 396. Angular-stemmed Mistletoe. 1.

V. articulatum, Burm.; DC. Prod. iv. 284; Fl. Austr. iii. 396. Articulated-stemmed Mistletoe. 6.

\section{Ord̉er BALANOPHOREZE.}

BALANOPHORA, Forst.

B. fungosa, Forst. ; Char. Gen. 99, t. 50; Fl. Austr. vi. 232 . 1, 2, 5,7 .

This root parasite was noticed to be very abundant in all the scrubs, producing unusually large heads, some noticed being over $3 \mathrm{in}$. diameter, and varying from nearly white to dark reddish-brown. $\mathrm{Mr}$. Banuing, of Freshwater Creek, says that "bullocks are so eager to obtain a bite of it that it is often difficult to drive them through a scrub where it abounds."

\section{Order EUPHORBIACEÆ.}

\section{EUPHORBIA, Linn.}

E. serrulata, Reinw.; Boiss in DC. Prod. xv. ii. 25; Fl. Austr. vi. $51 . \quad 1$.

E. pilulifera, Linn.; Boiss in DC. Prod. xv. ii. 21 ; Fl. Austr. vi. 51. Asthma-herb. 1.

\section{PHYLLANTHUS, Linn.}

P. Ferdinandi, Muell. Arg. in Fl. 1865, 379, and in DC. Prod. xv. ii. 300; Fl. Austr. vi. 96. Towwar. 1, 7.

P. minutiflorus, F. v. $M r$; Herb.; Muell. Arg. in Linnæa, xxxiv. 75, and in DC. Prod. xv. ii. 398 ; Fl. Austr. vi. 112. 7.

BREYNIA, Forst.

B. stipitata, Muell. Arg. in DC. Prod. xv. ii. 442 ; Fl. Austr. vi. 114. 7. 


\section{ANTIDESMA, Linn.}

A. Dallachyanum, Baill.; Adans. vi. 337 ; Tl. Austr. vi. 85. Herbert River Cherry. 1, 7.

The trees of this excellent fruit were in many localities heavily laden with fruit.

\section{ALPURITES, Fiorst.}

A. moluccana, Willd.; Muell. Arg. in DC. Prod. xv. ii. 733 ; Fl. Austr. vi. 128. Candle-nut. 1, 2, 5, 7 .

\section{CROTON, Linn.}

C. phebalioides, $F \cdot v . M$.; Muell. Arg. in Fl. 1864 (Oct.) 485, and in DC. Prod. xv. ii. 581; Fl. Austr. vi. 125.

C. arnhemicus, var. urenæfolius; Fl. Austr. vi. 128. 5.

CODINUM, Rumph.

C. variegatum, var. moluccanum, ILuell. Arg. in DC. Prod. xv. ii. 1119 ; Fl. Austr. vi. 147. 1, 5, 7 .

CLAOXYLON, A. Juss.

C. Hillii, Benth.; Fl. Austr. vi. 131. 1, 7.

\section{MALLTUS, Lour.}

M. claoxyloides, var. macrophylla, Muell. Arg. in Linnæa, xxxiv. 192, and in DC. Prod. xv. ii. 972 ; Fl. Austr. vi. 140. 1, 7.

Mr. angustifolius, Benth.; Fl. Austr. vi. 141. 7.

IM. philippinensis, MLuell. Arg. in Linnæa, xxxiv. 196, and in DC. Prod. xv. ii. 980; Fl. Austr. vi. 141. Kamela-tree. 7.

MACARANGA, Thou.

Tr. involucrata, Baill.; Etud. Euph. 432 ; Fl. Austr. vi. 146. 7. IM. Tanarius, Muell. Arg. in DC. Prod. xv. ii. 997; Fl. Austr. vi. 146. Tumkullum. 1, 7.

\section{RICINUS, Linn.}

R. communis, Linn.; Roxb. Ind. Fl. iii. 689. Castor-oil shrub, or Palma Christi. Seen as an escape from cultivation in many localities.

TRAGIA, Linn.

T. novæ-hollandiæ, Mfuell. Arg. in Linnæa, xxxiv. 180, and in DC. Prod. xv. ii. 929 ; Til. Austr. vi. 138. Climbing Nettle. 7.

\section{HOHALANTHLS, Linn.}

I. populifolius, Grah.; Bot. Mag. t. 2780. Pacific Islands Poison-bush. 1,7 .

\section{OMPHALEA, Linn.}

O. queenslandiæ, n. sp. 5. A rampant climbing plant, extending 100 or more feet; stems terete, or with more or less prominent decurrent lines from the base of the petioles; central pith abundant. Leaves alternate, broadly ovate or oblong, obtusely acuminate, broad almost truncate at the base, entire, 5 to $6 \mathrm{in}$. long, 3 to 4 in. broad 
at the base or sometimes twice that size, glabrous and deep green; petioles 1 to 2 in. long with 2 sessile rather large glands at the top; nerves 5 to 7 on each side of the midrib, the lowest pair starting from the top of the petiole, the smaller reticulations fine, but prominent in the dried leaf. Inflorescence slightly ferruginously pubescent, in pedunculate cymes in the upper axils of lateral shoots, somewhat trichotomously branched, about 2 in. long and broad. No male flowers found in the inflorescence examined. Female perianth of 5 imbricate hairy lobes, $1 \frac{1}{2}$ line long, the flowers very variable as to size and length of pedicels, some quite sessile; style very short with 3 spreading stigmatic branches. Fruit large, globular, yellow or nearly white, 3 to 5 in. diameter, 2 to 3 or in some 4-celled; exocarp thick, fleshy, ultimately separating into as many cocci, with a thin hard endocarp containing a solitary globular seed. The flowers may probably sometimes have 4 stigmatic lobes.

The specimens from which the above description was written were received some years ago from Dr. Thos. L. Bancroft, when that gentleman was on the Johnstone River, and the nuts were described by him as edible. At the time I felt diffident about publishing the plant as new, so placed it in the herbarium, marked "Near Omphalea," this American genus seeming its nearest ally. While on the Belienden-Ker expedition I frequently noticed the plant and saw fruit on the ground, but could obtain no flowers. However, I have ventured to name it as a new species of Omphalea, although no male flowers are yet to hand. I notice also, in a late issue of the Townsville Bulletin, that some nuts collected by Mr. Christie Palmerston were sent to the Royal Gardens, Kew, and the authorities there considered one of these nuts to belong to some species of Omphalea, probably the same plant here described. I did not obtain the native name; but the name there given is "Coorwah." Plants for years have been growing at Bowen Park which were raised from Jolnstone River sceds.

A species, O. oleifera, Hemsley, at Salvador, Sonsonate, is called by the natives "Tambor," and Dr. Dorat says that it yields a large quantity of a very fine oil, pleasant to the tastc, and resembling castor oil in its purgative qualities, with the advantage that its action is painless. Bio. Cent.-Ame. (Botany) iii. 134.

Dr. Lindley, Veg. King. p. 279, says that the juice of a Guayana specics, O. triandra, turns black in drying, and is there used in the place of ink. I notice that the coagulated sap of our native plant often forms small black lumps on the branches.

EXCECARIA, Linn.

E. Agallocha, Linn.; Muell. Arg. in DC. Prod. xv. ii. 1220; Fl. Austr. vi. 152. Milky Mangrore. 5.

\section{Order URTICACER.}

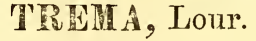

T. aspera, Blume; Mus. Bot. ii. 58; Fl. Austr. vi. 158. Peachleaf Poison-bush. 1.

T. orientalis, Blume; Mus. Bot. ii. 62; Fl. Austr. vi. 158. Gunpowder Charcoal tree of India. 7.

APHANANTHE, Planch.

A. philippinensis, Planch. in Ann. Sc. Nat. ser. 3, x. 337 ; Fl. Austr. vi. 160.7.

PSEUDOMORUS, Bureau.

P. Brunoniana, Bureau in Ann. Sc. Nat.s ser. 5; xi. 372; Fl. Austr. vi. 181. 1, 7 . 


\section{FICUS, Linn.}

F. colossea, F. v. M.; Fl. Austr. vi. 163. 7. A large deciduous tree with smooth light-coloured bark, remarkable for its branches being chosen by the bird Calornis metalica, or starlet, to build its nest upon. .

F. Cunninghamii, Mriq. in Ann. Mus. Lugd. Bot. iii. 386; Fl. Austr. vi. 165. 7.

F. eugenioides, F. v.M.; Miq. in Ann. Mus. Lugd. Bot. iii. 283; Fl. Austr. vi. 166.7.

F. ehretioides, F. $v . M 1$; Fl. Austr. vi. 171. 1, 7.

F. mollior, F.v. MI. ; Fl. Austr. vi. 173. 1.

F. Pinkiana, F. v. MI.; Syn. Queensl. Fl. 489. 5, 7 .

F. hispida, Linn.f.; Suppl. 442; Fl. Austr. vi. 176. 1.

F. fasciculata, $F . v . M$. ; Fl. Austr. vi. 177. 1.

F. casearia, F. v. MI. ; Fl. Austr. vi. 177. 1, 2.

F. glomerata, Willd.; Spec. Pl. iv. 1148; Fl. Austr. vi. 178. Cluster Fig. 1, 7 .

F. crassipes, $n . s p$. (So named from the thick stalk of fruit.) A large tree with a somewhat smooth light-coloured bark, very milky, ends of the branches very thick, marked with rings showing where the stipules were attached. Leaves alternate, very close on the ends of the branches, the internodes not being more than $\frac{1}{4}$ in. long; petioles somewhat flattened, about $3 \mathrm{in}$. long and 3 lines broad, glabrous or slightly hoary; lamina ovate or obtuse-ovate, with or without a short blunt point, usually rounded at the base, 5 to 8 in. long, 4 to $5 \frac{1}{2}$ in. broad, thick, coriaceous, and deep green, the margins entire, the primary lateral veins parallel, except the basal pair, which starting from the top of the petiole meet the other at about $\frac{1}{4}$ up the leaf where, anastomosing with them, form intramarginal ones. Stipules about 2 in. long with very fine point. Reoptacles crowded at the ends of the branches, obtusely 3-angular, some showing a fourth angle, about 2 in. long and 1 in. diameter, marked with oval purple spots, the apex beaked; peduncles 3 -angular, often broader than long.

Hab. : Scrubs, Harvey's Creek, Russell River.

This fine tree resembles somewhat, in its long angular fruit, F. pleurocarpa of the Johnstone River.

\section{CUDRANIA, Tréc.}

C. javanensis, Trécul. in Ann. Sc. Nat. ser. 3, viii. 123 ; Fl. Austr. vi. 179. Cockspur Thorn. 1,7 .

On the plants of this shrub growing along the Mulgrave River I found the leaves to be much affected by the parasitic fungus Rhytisma hypoxanthum.

\section{LAPORTEA, Gaudich.}

I. phosiniphylla, Wedd. ; Mongr. Urt. 138, in DC. Prod. xvi. i. 83 ; Fl. Austr. vi. 192. Shining-leaved Nettle-tree.

I. moroides, Wedd.; Mongr. Urt. 142, and in DC. Prod. vii. i. 88; Fl. Austr. vi. 192. Gympie Nettle-tree. 1, 7.

On the Mulgrave River the leares of this Nettle were unusually large; some measured 19 in. by 19 in. on petioles of 15 in. long. 


\section{ELATOSTEMMA, Forst.}

E. reticulatum, Wedd. in Ann. Sc. Nat. ser. 4, i. 188, and in DC. Prod. xvi. i. 176 ; Fl. Austr. vi. 183. 2.

\section{PIPTURUS, Wedd.}

P. argenteus, Wedd. in DC. Prod. xvi. i. 235 ; Fl. Austr. vi. 185. Coomeroo-coomeroo. 5,7 .

\section{Order CASUARINEZ. \\ CASUARINA, Linn.}

C. suberosa, Ott. Dietr. in DC. Prod. xvii. ii. 337 ; Fl. Austr. vi. 197. Swamp or River Oak. 7.

C. torulosa, Ait.; Hort. Kew, iii. 320 ; Fl. Austr. vi. 200 . Forest Oak. 2.

\section{Order CONIFER $\mathbb{E}$.}

\section{CALLITRIS, Vent.}

C. Parlatorei, F. v. M. ; Fragm. v. 186; Fl. Austr. vi. 23. Stringybark Pine. 2.

Until now this Cypress Pine has not been found except in the south of Queens. land. It was first found on the Darlington Range by Walter Hill.

PODOCARPUS, L'Hér.

P. elata, R.Br.; Mirb. in Mem. Mus. Par. xiii. 75 ; Fl. Austr. vi. 247. She-Pine or Kidneywallum. 2, 3, 7.

\section{AGATHIS, Salisb.}

A. robusta, C. Moore ; F. v. M. in Trans. Pharm. Soc. Vict. ii. 174; Fl. Austr. vi. 244. Dammara Pine. 3.

\section{Order CYCADACEZ.}

CYCAS, Linn.

C. media, R. Br. ; Prod. 348 ; Fl. Austr. vi. $249.1,7$.

\section{MACROZAMIA, Miq.}

M. Hopei, W. Hill ; 1st Suppl. Syn. Queensl. Fl. 53. 2.

BOWENIA, Hook.

B. spectabilis, Hook.; Bot. Mag. t. 5398; Fl. Austr. vi. 254. 5,7 .

The rhizome of this plant is used for food by the aborigines.

\section{Class II. IMONOCOTYLEDONS.}

\section{Order HYDROCHARIDEXE.}

BLYXA, Thou.

B. Roxburghii, Rich. in Mem. Inst. Fr. 1811, 77, t. 5 ; Fl. Austr. vi. 258.5 . 


\section{VALLISNERIA, Linn.}

V. gracilis, n. sp. (Plant small and slender compared with others of the genus.) Stems slender, creeping in the mud. Leaves about 7 or 8 to a plant, very narrow like fine grass, 3 to $5 \mathrm{in}$. long and about $\frac{1}{2}$ line broad, the sheathing base short, tapering to filiform points, all submerged, no portion floating on the surface of the water. Male flowers minute; female flowers on very fine, filiform, spirally twisted stalks; perianth of 3 ovate entire segments; stigmas 3.

Hab.: Still waters, or at the edge of the running waters of the Mulgrave River.

The above is from note made on the spot, and having but a common lens I could not fully describe the flowers.

\section{Order SCITAMINEE.}

\section{MUSA, Linn.}

IM. Banksii, F. v. M. ; Fragm. iv. 132; Fl. Austr. iv. 261. Aboriginal name, "Chatum." 1, 5.

III. Hillii, F.v.MI.; Fragm. ix. 169. Erect-flowering Banana. 1, 5. These indigenous Bananas should be tried for their fibre, which probably might be found stronger than that of the cultivated varieties; and they are in great abundance on the low lands of tropical Queensland.

\section{FLETIARIA, White.}

E. Scottiana, F. $v$. $\mathbb{M}$.; Fragm. viii. 24; Fl. Austr. vi. 264. Queensland Cardamoms. 1, 5.

ALPINIA, Linn.

A. cæralea, Benth.; Fl. Austr. 'vi. 265. 1, 7.

A. racemigera, F. v. MI.; Fragm. viii. 27 ; Fl. Austr. vi. 265. 1, 2.

A. arctiflora, F.v. MI. ; Fragm. viii. 25 ; Fl. Austr. vi. 266.5.

\section{TAPEINOCHELLS, Miq.}

T. pungens, Miq. in Ann. Mus. Lugd. Bat. iv. 101, t. 4; Fl. Austr. vi. 267 ; Sys. Queensl. Fl.811. 1,5, 7.

\section{Order ORCHIDEAE.}

\section{IIPARIS, Rich.}

I. reflexa, Lindl.; Bot. Reg. under n. 882; Fl. Austr. vi. 272.3.

This plant was in great abundance on the rocks from $4,000 \mathrm{ft}$. to the summit of Bellenden-Ker, but from my notes and the dried specimens there is nothing to separate them even as a form from the Southern plant. However, should the plants live which I have brought down, a distinction may afterwards be pointed out.

\section{MICROSTYLIS, Nutt.}

M. Bernaysii, F. v. M. ; Fragm. xi. 21. 3.

It is most fortunate to have rediscovered this plant, because all the specimens and plants had been lost which had previously been collected in the neighbourhood of Trinity Bay.

\section{OBERONLA, Lindl.}

O. pusilla, n. sp. 3. (A weak small species.) A small lightgreen plant, thickly studding the bark of a Myrtus. Leaves slightly distichous, about 4 or 5 to a plant, semi-cylindric, foveolate, fleshy, not over $1 \mathrm{in.long}$ and 1 line thick. Flower-racemes slightly exceeding 
the leaves and bearing about 12 minute flowers, each of which is subtended by a transparent bract. Fruit white, globular, about 1 line diameter.

Hab. : Bellenden-Ker, at about $4,000 \mathrm{ft}$. above sea-level.

No fresh flowers found on the plants; only found the plants on one tree, on which they were very numerous. Unfortunately all the live plants became rotten before they reached Brisbane.

DENDROBIUM, Swartz.

D. unduiatum, R.Br. ; Prod. 332; Fl. Austr. vi. 278. 1.

D. speciosum, Sm. ; Exot. Bot. i. 17, t. 10; Fl. Austr. vi. 279. 4, and top of Walsh's Pyramid, Mulgrave River.

D. speciosum, var. fusiforme, Bail.; Syn. Queensl. Flora, 509. $1,2$.

D. tetragonum, A. Cunn. in Bot. Reg. 1839; Misc. 33; Fl. Austr. vi. $279 . \quad 1,2$.

D. canaliculatum, R. Br.; Prod. 333; Fl. Austr. vi. 282.7.

D. hispidum, var. Waylori, Bail.; 1st Suppl. Syn. Queensl. W'l. $55,2,3$.

D. teretifolium, R. Br.; Prod. 333; Fl. Austr. vi. 285. 1, 7.

BULBOPHYLLUH, Thou.

B. lichenastrum, F. v. M. ; Fragm. vii. 60 ; Fl. Austr. vi. 287. $1,2,3$.

B. Toressæ, n. $s p$. (After Miss Toressa Meston.) A small plant with creeping rhizome adhering close to the granite rocks by roots frrom the under side, extending to 2 or 3 in. in length, often forming radiating patches. The upper surface closely covered by distichous, closely sessile, ovate-lanceolate, rugose leaves, which are so concave on the upper face as to be somewhat cymbiform, 3 or 4 lines long, with a single nearly sessile flower nestling at the base. Flowers yellowish-white, subtended by a prominent scarious bract; 3 outer segments broad and about 2 lines long, the lateral ones forming a short, blunt, almost truncate spur; the inner segments white, of delicate texture, and nearly the length of the outer ones. Labellum of equal length with the other segments, 3-lobed, lateral lobes dotted with purple, very short; middle lobe blunt and thick, bright yellow ; coluınn short and, for the size of the flower, prominently winged.

Hab.: On the shady rocks, Whelanian Pools; in flower in June and July.

B. nematopodum, F. v. MI.; Fragm. viii. 30 ; Fl. Austr. vi. 287. 2. Stipulary bract rigidly ribbed. Outer segment of flower with a purple edge, and 3 purple lines down the centre; inner segments about half the length of outer, say about $1 \frac{1}{2}$ lines, margin and one line down centre purple. Labellum $\frac{3}{4}$ as long as outer segments, and very velvety, with purple hairs; column length of inner segments.-Note from pocket-book.

B. Baileyi, F.v.MI.; Fragm. ix. 5. 1, 2, 3.

B. Prenticei, F. v. MI. in Wing's South Sc. Record i. 173; Syn. Queensl. Flora, $513 . \quad 3,4$.

B. purpurascens, Bail.; Procd. Roy. Soc. Queensl. 1; 1st Suppl. Queensl. Fl. 55. 2. 
ERIA, Lindl.

E. Fitzalani, F. v. $M$. in Wing's South Sc. Record ii. 252 ; Syn. Queensl. Flora, 513. 1.

PHOLIDOTA, Lindl.

P. imbricata, Lindl. in Hook. Exot. Fl. ii. t. 138; Fl. Austr. vi. 190. 1.

CYMBIDIUM, Swartz.

C. albucifiorum, F. v. $M$. ; Fragm. i. 188; Fl. Austr. vi. 303. Aboriginal name, "Pongeum." 1.

Mr. C. Fedley says that the native name for this plant at Port Curtis is "Dampy-ampy," where, as in other parts, they use it for food.

CLEISOSTOMA, Blume.

C. Macphersonii, F. v. M. ; Fl. Austr. vi. 297. 5,7 .

GALEOLA, Lour.

G. foliata, F. v. MI.; Frag. viii. $3 \mathrm{~L}$; Fl. Austr. vi. 307. 7 .

CORYMBIS, Thou.

C. veratrifolia, Reichb. $f$. in Fl. 1865, 184; Fl. Austr. vi. 311. $1,5,7$.

GO0DYERA, R. Br.

G. viridiflora, Blume; Orchid, 41, 9 c; Fl. Austr. vi. 313. 3.

THELYMITRA, Forst.

T. longifolia, Forst.; Char. Gen. 98, t. 49 ; Fl. Austr. vi. 319. 6,7 .

This wide-spread terrestrial orchid was only met with on the summits of Bartle Frere and Walsh's Pyramid.

\section{Order AMARYLLIDEX.}

CURCULIGO, Gærtn.

C. recurvata, Ait. ; Hort. Kew. ed. 2, ii. 253 ; Fl. Austr. vi. 448. 5. CRINUM, Linn.

C. pedunculatum, R. Br.; Prod.; Fl. Austr. vi. 455. 5 .

EURYCLES, Salisb.

E. amboinensis, Loud.; Encycl. Pl. 242; Fl. Austr. vi. 456.7.

\section{Order TACCACE王。}

TACCA, Forst.

T. pinnatifida, Forst.; Kunth. Enum. v. 458 ; Fl. A ustr. vi. 458. 7.

The rootstock of this plant furnishes the article known in commerce as " Fiji arrowroot," which is particularly recommended in cases of dysentery and diarrhoea. 


\section{Order DIOSCORIDEAE.}

DIOSCOREA, Linn.

D. sativa, Linn.; Spec. Pl. 1463 ; Hort. Cliff. t. 28 ; Fl. Austr. vi. 461. Yam. 1, 7 .

\section{Order IILIACEEE.}

SMIILAX, Linn.

S. glycyphylla, $S m$. in White Voy. 230 ; Fl. Austr. vii. 7. Sweet. Tea-plant. 1, 2, 3, 4 .

S. australis, R.Br.; Prod.; Fl. Austr. vii. 7. Sarsaparilla. 1, 7.

RHIPOGONUM, Forst.

I. album, var. leptostachya, Benth.; Fl. Austr. vii. 9. 1.

FLAGELLARIA, Linn.

F. indica, Linn.; Kunth. Enum. iii. 370 ; Fl. Austr. vii. 10. 1, $2,3,5,7$.

DIANELLA, Lam.

D. cærulea, Sims; Bot. Mag. t. 505; Fl. Austr. vii. 16. Blueberry. 7.

D. ensifolia, Red. Lil. t. 1 ; Fl. Austr. vii. 16. 1.

EUSTREPHUS, R. Br.

E. latifolius, $R$. Br.; Prod.; Fl. Austr. vii. 18. 1, 7.

DRACENA, Linn.

D. angustifolia, Roxb.; Bak. in Journ. Linn. Soc. xiv. 526 ; Fl. Austr. vii. 20. 1, 7 .

CORDYLINE, Comm.

C. terminalis, Kunth; Bak. in Journ. Linn. Soc. xiv. 539. Lily Palm. 1, 2, 3, 7 .

The usual tropical forms of this were met with both in flower and fruit.

BORYA, Labill.

B. septentrionalis, F. v. $M$. ; Fragm. v. 41 ; Fl. Austr. vii. 71. Walsh's Pyramid.

\section{Order PHILYDRACEZE.}

\section{HELMHOLTZIA, F. v. M.}

II. acorifolia, F. v. M. ; Fragm. v. 203 ; Fl. Austr. vii. 75. 3, 4. The gullies with running water, at from 4,000 ft. to the summit of Bellenden-Ker, seem to be the home of this noble plant, for we here found it growing in great profusion. The stems 3 to 5 feet high and over 2 in. in diameter, the upper portion bearing distichous flaglike leaves often $5 \mathrm{ft}$. long and 3 or $4 \mathrm{in}$. broad, of a deep-green colour. The flowers are pure white and borne on a terminal panicle 2 or 3 feet long; bracts closely reflexed, lanceolate; flowers $\frac{3}{4}$ in. long, 
of 3 segments, outer one greenish, inner ones white and tomentose, infolding the solitary stamen, of which the filament is short and the anther large and bright-yellow; ovary woolly; style glabrous, about as long as the perianth; stigma minute ; capsule 3 -lobed, containing numerous oblong or oblong-cuneate seeds.

It is most probable, when Sub-Inspector Johnstone mentions finding the Lord Howe's Island Morca Robinsoniana on the part of Bellenden-Ker visited by Mr. W. Hill and him in November, 1873, that this Helmholtzia is the plant referred to, as one might mistake the foliage of the one for the other when only casually examined.

\section{Order COMMELYNACEE.}

COMMELYNA, Linn.

C. cyanea, $R$. Br.; Prod.; Fl. Austr. vii. 84. Spider-wort. 1. C. lanceolata, $R$. Br.; Prod.; Fl. Austr. vii. 84. 7.

ANEI LEMA, R. Br.

A. acuminatum, $R$. Br. ; Prod.; Fl. Austr. vii. 85. 7 .

POLLIA, Thunb.

P. macrophylla, Benth.; Fl. Austr. vii. 90. 1, 5, 7 .

XEROTES, Banks.

X. longifolia, $R$. Br.; Prod.; Fl. Austr. vii. 97. 1, 2, 3, 7 .

\section{Order JUNCACEZE.}

XANTHORRHEA, Sm.

X. arborea, $R$. Br.; Prod.; Fl. Austr. vii. 115. Grass-tree. 7.

X. quadrangulata, F. v. MI. ; Fragm. iv. 111 ; Fl. Austr. vii. 117.

7. Walsh's Pyramid, Mulgrave River.

\section{CALAMUS, Linn.}

C. australis, Mart.; Hist. Nat. Palm. iii. 342 ; Fl. Austr. vii. 134. Large Lawyer Cane. 1, 5, 7 .

C. caryotoides, Mart.; Hist. Nat. Palm. iii. 338 ; Fl. Austr. vii. 135. Small Lawyer Cane. 1, 2, 3, 5, 7 .

\section{Order PALM ÆE.}

\section{BACULARIA, F. v. M.}

B. monostachya, F. v.M. ; Fragm. vii. 103 ; Fl. Austr. vii. 136. Midgeen Cane. 1, 2.

B. minor, F.v.MI.; Fragm. viii. 235 ; Fl. Austr. vii. 137. 2, 3. This is a very slender palm, 3 to 6 feet high; the stem not exceeding $\frac{1}{2}$ in. in thickness. The leaves have numerous narrow segments, about 16 , the upper one not at all or very little broader than the others; the inflorescence very slender erect spikes amongst the leaves; fruit cylindric. 
B. Palmeriana, $n . s p$. (After Edward Palmer, M.L.A., to whom we are indebted for much useful information as to the uses made by the aboriginal of our indigenous plants.) Stem slender, seldom exceeding $\frac{1}{2}$ in. diameter, generally much less than that; height not over 5 feet, usually 2 or 3 feet when in fruit; leafy at the top, 6 to 10 forming the crown. Leaves, sheathing bases 3 or 4 in. long, prominently striated or ribbed, with thin scarious edges which do not form stipule-like lobes at the top; midrib forming a sharp projecting angle; petioles erecto-patent, 6 to 9 in. long, 1 to 2 lines broad, semi-terete; rhachis 4 to 7 in. long; segments 1 or 2 pairs, their bases broadly adnate to the rhachis and slightly decurrent, somewhat widened above the base, thence tapering to often a long acute point, the outer edge of the upper part with prominent teeth. Inflorescence erect, slender, numerous amongst the leaves; peduncles flattened or semi-terete, 6 to $9 \mathrm{in}$. long; spike 3 to 5 in. long, enclosed at first in a membranous spatha, which is affixed immediately below the lowest flowers, open along one side. Flowers very small, but not gathered in a fit state to examine; young fruit gathered cylindric, somewhat fusiform or an elongated cone 4 to 6 lines long and 1 or 2 lines diameter. The whole plant more or less furfuraceous, those on the mountain top much more so than the others. My specimens were gathered at the base of the leading spur, at about 2,000 feet, and from that to the summit of the south peak, an altitude of over 5,000 feet.

In inflorescence it resembles Bacularia minor, F. v. M., but is widely different in foliage, the leaves being often so like Nengella flabellata, Becc., that they might be taken as belonging to that plant. From Baron Mueller's remarks, Fragm. xi. 58 and $x .121$, it is probable that examples of this new species may have been forwarded to him in association with those of the Bacularia above referred to.

\section{PTYCHOSPERMA, Labill.}

P. laccospadix, Benth.; Fl. Austr. vii. 140. 3, 4 .

IICUALA, Rumph.

I. Muelleri, Wendl. et Drude in Linnæa xxxix. 223 ; Fl. Austr. vii. $145.5,7$.

\section{Order PANDANEAE.}

PANDANUS, Linn.

P. pedunculatus, $R . B r$. ; Prod.; Fl. Austr. vii. 149. Screw Pine. 1,7 .

P. monticola; F. v. MI.; Fragm. v. 40, vii. 63 , and viii. 220 ; Fl. Austr. vii. 150. 1, 2, 3, 7 .

FREYCINETIA, Gaudich.

F. Gaudichaudii, $R$. Br. et Benn.; Pl. Jav. Rar. 31, t. 9; Fl. Austr. vii. 151 . 1, 5, 7 .

F. excelsa, $F . v . M$. ; Fragm. v. 39 ; Fl. Austr. vii. 151. 1, 5, 7.

\section{Order AROIDE五.}

TYPHONIUM, Schott.

T. Brownii, Schott; Aroid. 11, t. 15; Fl. Austr. vii. 154. 7. 
COLOCASIA, Schott.

C. antiquorum, Schott; Meletem. 18; Prod. ; Syst. Aroid. 138; Fl. Austr. vii. 155. Wild Taro. 5, 7.

Dr. Dymock, the highest authority on the medicinal uses of the plants of India, tells us that " the tubers of these plants chopped fine, tied in a cloth and heated, are used as a fomentation in rheumatism."

C. macrorrhiza, Schott; Meletem. 18; Prod.; Syst. Aroid. 138; Fl. Austr. vii. 155. Cunjevoi. 1, 7.

The form of this plant which we most frequently met with on scrub land was that with mottled leaf-stalks (C. macrorrhiza, var. brisbanica, Bail.).

\section{RHAPHID0PHORA, Hassk.}

R. pinnata, Schott in Bonplandia v. 45; Prod.; Syst. Aroid. 384; Fl. Austr. vii. 156. 1, 2, 5, 7.

\section{GYMNOSTACHYS, R. Br.}

G. anceps, $R$. Br.; Prod.; Fl. Austr. vii. 157. "Boorgay" of the natives, who use the leaves for string. $1,2,3,5,7$.

Probably this produces one of the strongest fibres known.

POTHOS, Linn.

P. Ioureiri, Hook. et Arn.; Bot. Beech. Voy. 220 ; Fl. Austr. vii. 158. Koi. 1, 2, 3, 5, 7 .

The fruit of this common climbing plant is used for food by the natives after being simply roasted ; their name for the ripe red berries is "Coyoi" or "Koi."

\section{Order LEMNACEZE.}

LEMNA, Linn.

I. minor, Linn.; Hegelm. Lemn. 142, t. 9, 10 ; Fl. Austr. vii. 163. Small Duckweed. 7.

\section{Order NAIADE正.}

POTAMOGETON, Linn.

P. tenuicaulis, F. v. M. ; Fragm. i. 90, 244, viii. 217 ; Fl. Austr. vii. 171. Slender Pondweed. 7.

\section{Order CYPERACEEE.}

KYLLINGA, Rottb.

KK. monocephala, Rottb.; Ic. et. descr. Pl. 13, t. 4 f. 4 ; Fl. Austr. vii. 251. 1, 7 .

K. cylindrica, Nees; Kunth. Enum. ii. 133; Fl. Austr. vii. 252. 1 .

\section{CYPRUS, Linn.}

C. difformis, Linn.; Kunth. Enum. ii. 38; Fl. Austr. vii. 268. 7.

C. umbellatus, Benth.; Fl. Hongk. 386 ; Fl. Austr. vii. 289.7.

\section{FIMBRISTYLIS, Vahl.}

F. barbata, Benth.; Fl. Austr. vii. 321. 7. 
SCIRPUS, Linn.

S. mucronatus, Linn.; Kunth. Enum. ii. 161; Fl. Austr. vii. 332. 7.

FUIRENA, Linn.

F. glomerata, Lam.; Kunth. Enum. ii. 184; Fl. Austr. vii. 338. 1.

HYPOLYTRUM, Rich.

I. latifolium, Rich.; Kunth. Enum. ii. 271 ; Fl. Austr. vii. 339. 1,5 .

GAHNIA, Forst.

G. psittacorum, Labill.; Pl. Nov. Holl. i. 89, t. 115; Fl. Austr. vii. 418. 3, 4, and summit of Walsh's Pyramid.

\section{Order GRAMINE正.}

PASPALUM, Linn.

P. scrobiculatum, Linn.; Kunth. Enum. i. 53; Fl. Austr. vii. 460. Ditch Millet. 1, 2.

P. pubescens, $R$. Br. ; Prod. ? 5. If I am correct in identifying the plant, common at Harvey's Creek, as Brown's plant, then I think, if not allowed to rank as a species, it should undoubtedly as a marked variety. The whole plant is softly pubescent, attains about 2 feet in height, is of spreading habit, and roots from the lower nodes. The leaves are broad with loose sheaths, the short scarious ligula hidden in long silky hairs; panicle of from 8 to 14 somewhat erect spikes, the longest of which are about 2 in.; spikelets orbicular, about $\frac{1}{2}$ line diameter; glumes covered with a short purplish pubescence. The description given in Brown's Prodromus is insufficient to identify the plant without having a typical specimen to compare with. This Harvey's Creek grass, however, is so very distinct from the $P$. orbiculare, Forst., which-with $P$. polystachyum and $P$. pubescens of R. Brown-Bentham, in Fl. A ustr. vii. 460 , places under $P$. scrobiculatum of Linnæus, that I think it should be kept distinct.

P. distichum, Linn.; Kunth. Enum. i. 52 ; Fl. Austr. vii. 4601. P. brevifolium, Flügge; Kunth. Enum. i. 48; Fl. Austr. vii. 461. 7.

ERIOCHLOA, Humb. and Kuntb.

E. punctata, Hamilt.; Kunth. Enum. i. 72; Fl. Austr. vii. 463. Farly Spring Grass. 7.

ISACHNE, R. Br.

I. myosotis, Nees in Hook. Kew Journ. ii. 98; Fl. Austr. vii. 625.5 .

PANICUM, Linn.

P. parviflorum, R.Br; Prod.; Fl. Austr. vii. 470. 1, 7.

P. semialatum, $R$. Br.; Prod.; Fl. Austr. vii. 472. Cockatoo Grass. 1.

P. crusgalli, Linn.; Fl. Austr. vii. 479. Barnyard Grass. 5, 7. P. indicum, Linn.; Kunth. Enum. i. 133; Fl. Austr. vii. 480. 7. 
P. trichoides, Sw.; Kunth. Enum. i. 112 ; Fl. Austr. vii. 485. 1,7 .

P. Mitchelli, Benth.; Fl. Austr. vii. 489. 1, 7 .

OPLISMENUS, Beauv.

O. compositus, Beauv.; Agrostogr. 54; Fl. Austr. vii. 491. 1. $2,5,7$.

SETARIA, Beauv.

S. glauca, Beauv.; Kunth. Enum. i. 149; Fl. Austr. vii. 492. Pigeon Grass. $1,7$.

LEPTASPIS, R. Br.

I. Banksii, R. Br. ; Prod. 211 ; Fl. Austr. vii. 548. 1,7 .

IMPERATA, Cyr.

I. arundinacea, Cyr.; Kunth. Enum. i. 477; Fl. Austr. vii. 536. Blady Grass. 1, 2.

ELTONURUS, Willd.

E. citreus, Munro; Fl. Austr. vii. 510. Lemon Grass. 7.

HETEROPOGON, Pers.

H. contortus, Rom. et Schult.; Syst. ii. 386 ; Fl. Austr. vii. 517. Bunch Spear Grass. 7.

H. insignis, Thw.; Enum. Ceyl. Pl. 437; Fl. Austr. vii. 517. Tall Spear Grass. 1.

CHRYSOPOGON, Trin.

C. gryllus, Trin.; Fund. Agrost. 188, and in Mem. Acad. Petersb. ser. 6 , ii. 317 ; Fl. Austr. vii. 536. 7.

\section{SORGHUM, Pers.}

S. plumosum, Beauv.; Agrost. 132; Fl. Austr. vii. 540. 1, 7.

S. laxiflorum, n. sp. 7. Decumbent, ascending to 2 or 3 feet, glabrous, except the inflorescence and a slight downiness about the nodes, stems somewhat compressed. Leaves narrow, tapering to filiform points; ligula short, scarious, but almost hidden in the longish hairs at the top of the sheath. Panicle nodding, somewhat secund, 2 or 3 in. long, of few capillary branches never verticillate, solitary or in pairs and forked, each bearing usualiy 2 spikelets, the terminal one awned. Fertile spikelet scarcely 2 lines long, between two ciliate pedicels; outer glume densely clothed with dark-brown or at times light-brown hairs; second glume nearly glabrous, glossy, and of a very dark colour; third glume hyaline; awn over 1 in. long, much twisted in the lower half.

The awns of this Mulgrave River grass remind one of the Bunch Spear Grass by the manner in which they twist into knots, but it is a much more delicate grass. In inflorescence it approaches Chrysopogon, but the glumes are those of a Sorghum.

POGONATH HRUM, Beaut.

P. saccharoideum, Beauv.; Benth. Hongk. Fl. 421. 2, 3.

ANTHISTIRIA, Linn.

A. ciliata, Linn.; Kunth. Enum. i. 481; Fl. Austr. vii. 542. Kangaroo Grass. 1, 2, 7. 
ARISTIDA, Linn.

A. ramosa, $R$. Br.; Prod. 173 ; Fl. Austr. vii. 563 . Three-awned Spear Grass: 1 .

SPOROBOLUS, R. Br.

S. diander, Beauv.; Kunth. Enum. i. 213; Fl. Austr. vii. 622. 1, 7.

MICRAIRA, F. v. M.

IM. subulifolia, F. v. MI. ; Fragm. v. 208 ; Fl. A ustr. vii. 624.

The leaves of this plant on Mount Harold are more convolute when dry than is usually found in the Southern specimens.

ERIACHNE, R. Br.

E. avenacea, R. Br.; Prod. 184; Fl. Austr. vii. 629. 7.

An evident form of this species was met with on Walsh's Pyramid. It is of delicate growth, with a branching stem which attains the height of 2 feet.

ELEUSIYE, Gærtn.

E.. indica, Gartn.; Kunth. Enum. i. 272 ; Fl. Austr. vii. 615. Crab Grass. 1, 5, 7 .

\section{IEPTOCHLOA, Beauv.}

I. chinensis, Nees; Steud. Syn. Glum. i. 209; Fl. Austr. vii. 617. 1,7 .

ERAGROSTIS, Beauv.

E. Brownii, Nees in Steud. Syn. Glum. i. 279; Fl. Austr. vii. 646. Love Grass. 1.

\section{CENTOTHECA, Desv.}

C. lappacea, Desv.; Kunth. Enum. i. 366 ; Revis. Gram. t. 70 ; Fl. Austr. vii. 640 . 1, 5, 7 .

\section{BAMIBUSA, Schreber.}

B. Moreheadiana, n. $s p$. The Queensland Climbing Bamboo. (After the Hon. B. D. Morehead.) A rampant climbing plant scaling the tops of the highest trees of the scrubs, and hanging in festoons from the branches, probably the stems extending 200 or more feet in length. The largest diameter of stem measured 2 in., the hollow or pipe about one-third of its diameter; length of internode, under 1 ft.; the whole plant more or less clothed with dark-coloured bristlelike hairs or scales; stem-buds hemispheric, $\frac{3}{4}$ in. diameter; stemleaves with a lance-like lamina 2 or 3 in. long; the leafy shoots, which are numerous from the upper nodes, are much flattened, and the lamina of leaf measures from 6 to $10 \mathrm{in}$. long and from 1 to 2 in. broad, glabrous, with 6 or 7 parallel nerves on each side of the midrib, ending in filiform points, the margins entire except for a few distant minute teeth.

Hab.: Harvey's Creek, Russell River.

Already Baron von Mueller, in the Aust. Journ. of Pharm., 1886, drew attention to a Queensland species of Bamlusa, but the specimens and the collector's notes he thought insufficient to name the spccies; and even now, not having seen the inflorescence, by some it may be deemed too early to have given to it specific distinction, but the uncertainty of the flowering of plants of the genus, and that the stems are being put to many useful purposes, is, I consider, sufficient excuse; and when the-flowers and fruit are obtained the species can then be placed in the genus or tribe to which it may prove to belong. 


\section{Class III. ACOTYLEDONS.}

\section{Order LYCOPODIACEAE.}

LYCOPODIUH, Linn.

I. varium, R.Br.; Prod. 165 ; Fl. Austr. vii. 674. 3.

I. densum, Labill.; Pl. Nov. Holl. ii. 104, t. 251; Fl. Austr. vii. 676.6 .

I. phlegmaria, Linn.; Spring Monogr. Lycop. i. 63, ii. 28; Fl. Austr. vii. 674. Tasselled Club Moss. 1, 2.

I. phlegmarioides, Gaudich.; Freyc. Voy. t. 23; Bak. Fern Allies, 20 ; 1st Suppl. Syn. Queensl. Fl., 62. Tasselled Club Moss. 2.

I. cernuum, Linn.; Spring Monogr. Lycop. i. 79, ii. 37; Fl. Austr. vii. $676,1,2,5,7$.

SELAGINELLA, Spring.

S. Bakeriana, Bail.; 1st Suppl. Queensl. Flora, 62. 1, 2, 5, 7.

S. flabellata, Spring; Monogr. Lycop. ii. 174; Fl. Austr. vii. 678. $1,2,3,5,7$.

S. proniflora, Baker; Fern Allies, 108. 1, $2,7$.

S. pumilio, Spring; Baker's Fern Allies, 114. 7.

AZOLLA, Linn.

A. rubra, $R$. $B r$.; Prod. 167 ; Fl. Austr, vii. 680 . The Red Water Moss. $1,5,7$.

\section{TMESIPTLRIS, Bernh.}

T. tannensis, Bernh. in Schrad. Journ. 1800, ii. 131, t. 2, f. 5; Fl. Austr. vii. 680. 2, 3, 4 .

PSILOTUI, Swartz.

P. triquetrum, Swartz; Spring Monogr. Lycop. ii. 269 ; Fl. Austr. vii. 681. 1, 2.

\section{Order FILICES.}

OPHIOGLOSSUM, Linn.

O. pendulum, Linn.; Hook. and Bak. Syn. Fil. 446 ; Fl. Austr. vii. 689. Pendulous Adder's-tongue or Ribbon Fern. 2.

BOTRYCHIUM, Swartz.

B. ternatum, Swartz; Hook and Bak. Syn. Fil. 448 ; Fl. Austr. vii. 690. The Grape Fern. 7.

LYG0DIUM, Swartz.

I. reticulatum, Schkukr; Spec. Filic. 139, t. 139 ; Fl. Austr. vii. 692. Snake Fern. 1, 2, 3, 5, 7 .

I. japonicum, Swartz; Hook. and Bak. Syn. Filic. 439; Fl. Austr. vii. 692. Snake Fern. 7. 
ANGIOPTERIS, Hoffm.

A. evecta, Hoff $m$.; Hook. and Bak. Syn. Filic. 440 ; Fl. Austr. vii. 694. 2 .

MARATTIA, Sm.

II. fraxinea, Sm.; Ic. Ined. t. 48; Fl. Austr. vii. 695. Potato Fern. 1, 2, 3, 4 .

\section{GLEICHENIA, Sm.}

G. circinata, Swartz; Syn. Filic. 165, 394; Fl. Austr. vii. 697. Parasol Fern. 1, 3, 4 .

G. flabellata, R. Br.; Prod. 161 ; Fl. Austr. vii. 698. Fan Fern. $1,2,3,4$.

G. dichotoma, Hook; Spec. Filic. i. 12; Fl. Austr. vii. 698. $1,2,3,4,5$.

On Harvey's Creek stems of this beautiful fern were found to have attained the length of 30 feet by climbing up the surrounding shrubs and trees.

\section{TODEA, Willd.}

T. (Leptopteris) Fraseri, Hook. et Grev. ; Ic. Filic. t. 101 ; Fl. Austr. vii. 700. 4. Trunk erect, 6 in. to 3 feet high and seldom over 2 or $2 \frac{1}{2}$ in. diameter, more or less bearing the bases of the old fronds; the apex covered by somewhat glossy, short, obtuse scales; the crown of few fronds, generally under 12 . Stipes 10 to $15 \mathrm{in}$. long, terete or nearly so, with few scales, slightly stained with chestnut. Fronds 2 to 3 feet long, lanceolate in outline, bipinnate ; pinnæ nearly opposite, about 30 on each side of rhachis, the centre ones about 6 in. long and $1 \frac{1}{2}$ in. wide ; secondary rhachis narrowly winged; pinnules $\frac{3}{4} \mathrm{in}$. long, $2 \frac{1}{2}$ lines broad, serrately lobed; veins simple or forked, 1 to each tooth or lobe; spore-cases minute, in masses of from 2 to 5 at the base of the pinnule.

Hab. : In a deep rocky gully or creek on the summit of the south peak, Bellenden-Ker.

The thin dark-green pellucid fronds of this fern remind one of the New Zealand species T. (Leptopteris) hymenophylloides.

\section{TRICHOMANES, Linn.}

T. vitiense, Baker in Journ. Linn. Soc. ix. 338, t. 8 D.; Syn. Filic. 74 ; Fl. Austr. vii. 701. Fiji Bristle Fern. 1.

T. parvulum, Poir.; Hook. Spec. Filic. i. 118 ; Syn. Filic. 75 ; Fl. Austr. vii. 701. Small Bristle Fern. 2.

T. minutum, Blume; Hook. Spec. Filic. i. 118 ; Bl. En. Fil. Jav. 223. Minute Bristle Fern. 2.

This is the first time it has been met with in Australia.

T. proliferum, Blume; En. Fil. Jav. 224; Hook. Spec. Filic. i. 118. 2.

First time it has been met with in Australia.

T. joinnstonense, Bail.; Proc. Roy. Soc. Queensl. i. ; 1 st Suppl. Queensl. Fl. 63. Johnstone River Bristle Fern. 2.

T. Filicula, Bory; Duper. Voy. Bot. i. 283 ; Hook. Spec. Filic. i. 124 . $1,2,3,4,7$.

T. rigidum, Swartz; Hook. Spec. Filic. i. 133; Syn. Filic. 86; Fl. Austr. vii. 702. Rigid Bristle Fern. 1, 2, 3, 4 .

T. parviflorum, Poir.; Dict. viii. 83; Fl. Austr. vii. 704. Fennel-leaved Bristle Fern, 1, 2, 3. 
T. pallidum, Blume; En. Fil. Jav. 225 ; Hook. Spec. Filic. i. 139. White-leaved Bristle Fern. 4. This is the first time that it has been met with in Australia, and probably the summit of Bellenden-Ker is its only Australian habitat. The fronds are glaucous on the under side, which is unusual in the genus.

\section{HYMENOPHYLLUM, Sm.}

H. javanicum, Spreng.; Hook. Spec. Filic. i. 106; Syn. Filic. 60; Fl. Austr. vii. 705. Java Filmy Fern. 4.

H. tunbridgense, var. exsertum, Bail. The Bristle-bearing Filmy Fern. 3. This fresh form differs in having a long bristle-like exserted receptacle; the indusium also was longer than usual. The receptacle is also exserted in the Lord Howe's Island specimens of this fern but there the plant is of much coarser growth.

H. trichomanoides, $n . s p$. 4. Rhizome nearly or quite glabrous, filiform, creeping up the stems of trees in long strings, seldom if ever forming matted patches on old damp logs. Fronds narrow or broadly lanceolate in outline; sometimes the apex is much elongated, 3 to 5 in. long including the slender stipes, which is generally less than an inch long; the rhachis is very narrowly winged but not the stipes, bipinnate, the lower pinnules often somewhat flabelliform and more or less deeply divided, the upper pinnæ of from few to a single lobe, all linear, obtuse, with entire edges. Sori supra-axillary, deeply sunk on one or more of the lobes. Indusium oblong, $1 \frac{1}{2}$ line long, the valves entire, obtuse, receptacle always protruding from 1 to more than 2 lines in length.

Hab.: Summit of Bellenden-Ker. The outline form of this, especially when the pinnæ and pinnules are crowded, remind of $H$. polyanthos of New Zealand, but it does not stain paper, and has not the fragrance of that fern, besides the difference of indusium and receptacle, which latter gives to this new species the appearance of a Trichomanes. Indeed it might be placed in either Trichomanes or Hymenophyllum; I place it in the latter because the whole of the cxserted portion of the indusium consists of the 2 long obtuse lobes.

\section{ALSOPHILA, R. Br.}

A. Rebeccæ, F. v. MI. ; Fragm. v. 53, 117 ; Fl. Austr. vii. 710. $2,3,4$.

This liandsome fern-tree we found to be in greater abundance than any other. In fact, it at times formed much of the scrub we had to cut our way through.

A. capensis, J. Sm.; Hook. Spec. Filic. i. 36. Wig Fern-tree. 3. Trunk erect, 12 feet high, reddish, slender, seldom exceeding a diameter of 2 in. Fronds 6 to 8 feet long, the base of the stipes for a few inches pressed to the stem and here bearing a lyymenophylloid growth of a purplish or green and purple hue, thin as thread, and many times forked, giving a wigged-like appearance to the crown of the trunk; stipes and rhachis more or less clothed with long, simple, hair-like scales; centre pinnæ about 2 feet long, lanceolate, acuminate; secondary rhachis more or less covered with small fringed chaffy scales; pinnule 2 to $4 \mathrm{in}$. long, the attenuated apex serrated, the lower half with a rounded auricle at times very prominent, upper half truncate and parallel with the secondary rhachis; veins forked or at times simple; sori much elevated, almost cylindrical, on the middle of the vein.

Hab. : In a dcep rocky gully at Palm Camp, elevation about 4,000 fect. Never before found in Australia, although known from Soutl Africa, Brazil, and Java. 
It seems to have been first described by the great Linnæus as Polypodium capense, and according to Thos. Moore, Index Filicum, since then it has received from various authors no less than a dozen different names. One author even, we are told, thinking that the metanorphosed pinnæ and hair-like scales at the base of the stipes wcre a parasitic growth, gave to it the name of Trichomanes cormophyllum.

A. australis, R. Br.; Prod. 158; Fl. Austr. vii. 710. Australian Fern-tree. 5 .

A. Robertsiana, F. $v . M$. ; Fragm. v. 54, 117 ; Fl. Austr. vii. 712. Slender-stemmed Fern-tree. 3. Trunk slender, smooth, 10 to 12 feet high, elongated beyond the last fronds, which latter do not form the usual crown, but are somewhat distantly placed on the stem.

DICKSONIA, L'Hér.

D. Youngiæ, C. Moore in Bak. Syn. Filic. 461; Fl. Austr. vii. 713. Hairy-stemmed Fern-tree. 3.

DAVALLIA, Sm.

D. elegans, $S w . ;$ Hook. Spec. Filic. i. 164, t. 43 ; Syn. Filic. 95 ; Fl. Austr. vii. 715. Rock Hare's-foot Fern. 1, 2.

D. pyxidata, Cav.; Hook. Spec. Filic. i. 169, t. 55 ; Syn. Filic. 96 ; Fl. Austr. vii. 716. Common Hare's-foot. 6.

D. pedata, Sm.; Hook. Spec. Filic. i. 154, t. 45 ; Gard. Ferns, t. 7 ; Syn. Filic. 89; Fl. Austr. vii. 716 . Ivy-leaved Fern. 1, 2, 3, 4 .

D. speluncæ, Baker; Syn. Fil. 100; Fl. A ustr. vii. 717. 1, 23.

D. tripinnata, F. v.M.; ; 1 . Austr. vii. 717. Hairy Fern. 3, 4. The fronds, which are clothed with soft white hairs, form a most graceful tuft at the end of a very shortly creeping rhizome. The plant is abundant upon the damp rocks of dark close gullies.

This is one of the most lovely of ferns, and until quite lately was only known from a single frond brought by Mr. Walter Hill from the Bellenden-Ker Range in 1873.

\section{VITTARIA, Sm.}

V. elongata, Swartz; Hook. and Bak. Syn. Filic. 395; Fl. Austr. vii. 718. Grass-leaved Fern. 1, 2, 3, 4, 5, 7 .

V. (Tæniopsis) wooroonooran, n. sp. (Name, the aboriginal one for Bellenden-Ker.) 3, 4. Rhizome erect or slightly repent, clothed with long, light-brown, linear-lanceolate scales. Fronds 1 to $1 \frac{1}{2}$ in. long, 2 or 3 lines broad, coriaceous, spreading horizontally, very obtuse, tapering to a very short stipes, bearing minute, scattered, setose scales; veins once forked from a central costa, but both concealed by the thick substance of the frond; sori continuous in a groove more or less distant from the margin on the upper part of the frond, but never meeting at the apex.

Hab.: On rocks amongst moss at an clevation of from 4,000 to 5,000 feet, Bellenden-Ker.

In some respects this species approaches $V$. falcata and $V$. minor, but is equally distinct from both.

LINDSAEA, Dryand.

I. cultrata, Swartz; Hook. Spec. Filic. i. 203; Syn. Filic. 105; Fl. Austr. vii. 719.1.

I. Fraseri, Hook. ; Spec. Filic. i. 221, t. 70 ; Syn. Filic. 112 ; Fl. Austr. vii. 721. 1.

I. ensifolia, Swartz; Hook. Spec. Filic. i. 220; Syn. Filic. 112 ; Fl. Austr. vii. $721 . \quad 1,2,7$. 
I. Ianuginosa, Wall.; Hook. Spec. Filic. i. 210, t. 69; Syn. Filic. 109 ; Fl. Austr. vii. 722.

\section{ADIANTUM, Linn.}

A. æthiopicum, Linn.; Hook. Spec. Filic. ii. 37, t. 77; Syn. Filic. 123 ; Fl. Austr. vii. 724. Common small Maidenhair. 1, 7.

A. affine, Willd.; Hook. and Bak. Syn. Fil. 117; Fl. Austr. vii. 724. $1,2,3$.

A. diaphanum, Blume; Hook. Spec. Filic. ii. 10, t. 80; Syn. Filic. 117; Fl. Austr. vii. 725. A delicate Maidenhair. 1, 7.

A. hispidulum, Swartz; Hook. Spec. Filic. ii. 31; Syn. Filic. 126 ; Fl. Austr. vii. 725. Rough Maidenhair Fern. 7.

HYPOLEPIS, Bernh.

I. tenuifolia, Bernh.; Hook. Spec. Filic. ii. 60, t. 89, 90; Syn. Filic. 129 ; Fl. Austr. vii. 726, 1, 7 .

\section{CHELLANTHES, Swartz.}

C. tenuifolia, Swartz; Hook. Spec. Filic. ii. 82, t. 87 ; Syn. Filic. 138; Fl. Austr. vii. 726 . Lip Fern. 1, 7.

PTERIS, Linn.

P. geraniffolia, Raddi.; Filic. Bras. 46; Fl. Austr. vii. 728. Geranium-leaved Bracken. 7.

P. falcata, var. nana; Hook. Spec. Filic. ii. 136. 1, 2.

P. quadriaurita, Retz.; Hook. Spec. Filic. ii. 179, t. 134; Syn. Filic. 158; Fl. A ustr. vii. 731. 1, 2, 7.

P. tremula, R.Br.; Prod. 154; Fl. Austr. vii. 731. 7.

P. aquilina, Linn., var. Ianuginosa; Hook. Spec. Filic. ii. 196. The Woolly Bracken. At between 2,000 and 5,000 feet above sea-lerel we found some good-sized patches of this fern. It is a tall strong plant, very hard, but, from being closely covered with soft woolly down, has a somewhat soft appearance, and grows in iutricate masses 5 or 6 feet high, very difficult to pass through.

P. incisa, Thunb.; Hook. Spec. Filic. ii. 230 ; Syn. Filic. 172 ; Fl. Austr. vii. 732. 1, 2.

P. marginata, Bory.; Hook. and Bak. Syn. Filic. 172 ; Fl. Austr. vii. $733.1,5,7$.

\section{LOMALIA, Willd.}

I. Patersoni, Spreng.; Hook. Spec. Filic. iii. 3; Syn. Filic. 174; Fl. Austr. vii. 734. 2, 3. This fern was very plentiful at Palm Camp, and probably attains there a greater size than in any other locality in the Southern Hemisphere. Some frouds measured nearly 4 feet long, and the segments, of which there were on some fronds 14 or more on each side of the rhachis, over $10 \mathrm{in}$. long and $\frac{3}{4} \mathrm{in}$. wide. The undivided fronds were also long, but always shorter than the divided ones.

\section{BLECHNUM, Linn.}

B. cartilagineum, var. tropicum, Bail.; Syn. Queensl. Fl. 703. $1,2,3$.

B. serrulatum, Rich.; Hook. Spec. Filic. iii. 54; Syn. Filic. 186; Fl. Austr. vii. 739. 1. 
B. Whelani, n.sp. (After Sergt. E. J. Whelan, to whom the members of the expedition were greatly indebted for assistance.) Rhizome slender and erect, from 3 to 6 in. high, densely paleaceous at the summit, with ferruginous scales, and bearing a crown of many dark-green fronds; stipes blackish, slightly scabrous, clothed at the base with dark linear scales, about $1 \mathrm{ft}$. long and slender; the frond or leafy portion of about equal length with the stipes, bearing about 15 nearly opposite linear-lanceolate piunæ 3 to 6 in. long, the lowest of which are petiolulate, the central ones sessile, and one or two of the terminal ones having their bases adnate to the rhachis, the margins scrrated, teeth small and blunt, except those of the elongated point; veins simple or once forked; sori close to the costule on the lower half or three-fourths of the pinna.

Hab. : Bellenden-Ker at an elevation of from 4,000 to 5,000 feet above sea-lovel.

DOODIA, R. Br.

D. aspera, var. media, Bail.; Syn. Queensl. Fl. 704. 1, 7.

ASPLENIUM, Linn.

A. nidus, Linn.; Hook. Spec. Filic. iii. 77 ; Syn. Filic. 190 ; Fl. Austr. vii. 744. Bird's-nest Fern. 1, 2, 3, 5, 7 .

A. simplicifrons, F.v. M.; Fragm. v. 74; Fl. Austr. vii. 744 . Simple-leaved Spleen Fern. 1, 2.

A. attenuatum, $R$. Br.; Prod. 150 ; Fl. Austr. vii. 745. Attenuated Spleen Fern. 7.

A. paleaceum, $R$. Br. ; Prod. 150 ; Fl. Austr. vii. 746. Scaly Fern. 7.

A. falcatum, Lam.; Hook. Spec. Filic. iii. 160 ; Syn. Filic. 208 ; Fl. Austr. vii. $746 . \quad 1,2,3$.

A. Hookerianum, Colens., var. ; Hook. Spec. Filic. iii. 194; Syn. Filic. 213 ; Fl. Austr. vii. 747. 2, 3. Rhizome erect or shortly repent, the crown and base of stipes densely clothed with darkbrown scales; stipes tufted, slender, 4 or 5 jn. long, dark-brown and slightly scaly. Fronds bipinnate, narrow-lanceolate, in outline attaining $8 \mathrm{in}$. in length, and not over 3 in. wide in the broadest part; pinnules cuneate, the lower ones often divided to the base, the end inciso-dentate. Sori usually long and narrow.

A. resectum, var. australiense, Bail.; 1st Suppl. Queensl. Fl. 64. Hills off Mulgrave River.

A. laserpitiifolium, Lam.; Hook. Spec. Filic. iii. 171, t. 203; Syn. Filic. 215; Fl. Austr. vii. $748 . \quad 1,2,3$.

A. umbrosum, J. Sm.; Hook. Spec. Filic. iii. 231 ; Syn. Filic. 229 ; Fl. Austr. vii. 749. Shade-loving Spleen Fern. 2.

A. sylvaticum, Presl.; Hook. Spec. Filic. iii. 248; Syn. Filic. 232 ; Fl. Austr. vii. 750. Forest Spleen Fern. 5, 7.

A. polypodioides, Metten.; Hook. Spec. Filic. iii. 257 ; Syn. Filic. 238 ; F1. Austr. vii. $751.2,3,4$.

A. decussatum, Swartz; Hook. Spec. Filic. iii. 2.70 ; Syn. Filic. 243 ; Fl. Austr. vii. 751. Bulbil-bearing Spleen Feru. 1, 5.

On Harvey's Creek this species attains a great size, some of the fronds being over 6 feet long. 


\section{ASPIDIUM, Swartz.}

A. cordifolium, Swartz; Syn. Filic. 45 ; Fl. Austr. vii. 754. Tuberous Fern. 1.

A. exaltatum, Swartz; Syn. Filic. 45 ; Fl. Austr. vii. 754. Coast Rock Fern. 1, 2, 5, 7 .

A. ramosum, Beauv.; Fl. Ow. et Ben. ii. 53, t. 91 ; Fl. Austr. vii. 754. 1,2, 3. A climbing fern, the fronds often distant, pinnæ distant, over 1 in. long, the upper edge crenate and auricled at the base.

A. ramosum, var. lineare. 1,5 . Rhizome pubescent, very slender, climbing like ivy up to stems of trees and shrubs, often 10 or 12 feet. Fronds crowded, linear in outline, 6 to $15 \mathrm{in}$. long and seldom exceeding 1 in. broad; pinnæ 30 to 40 on each side of the rhachis, not exceeding 8 lines long in the centre of frond and much smaller towards each end, obliquely oblong, the upper margin slightly crenulate, with a short blunt auricle at the base, lower margin nearly straight, base parallel with the rhachis; terminal pinna lanceolate or somewhat rhomboidal; veins once forked; sori on the end of the upper branch usually at a distance from the margin.

Amongst the many forms of $A$. ramosum that have been considered distinct by botanists I cannot find one that fully agrees with the present, so think it better to give it a distinctive name. During the past few months, while on and about Bellenden-Ker, I have found it always the same in both habit and form, and even when growing with the normal form, is at once detected; the fronds being alwars long and narrow, and crowded so closely on the slender rhizome as to appear massed together.

A. molle, Swartz; Syn. Filic. 49 ; F]. Austr. vii. 756. Soft Shield Fern. 1, 2.

A. molle, var. didymosorus, Benth.; Fl. Austr. vii. 756. Twin-seeded Fern. 5, 7 .

A. confluens, Metten. in Linnæa xxxvi. 125; Fl. Austr. vii. 757. $1,2,3$.

A. decompositum, Spreng.; Syst. iv. 109 ; Fl. Austr. vii. 758. 3. A. acuminatum, var. villosum. 4. This delicate fern is met with only, so far as at present known, on the summit of BellendenKer. It has a shortly creeping rhizome, more or less covered at the end with broad brown scales; the stipes are slender, 3 to $6 \mathrm{in}$. long, clothed with short soft hairs, and a few scales at the base. Fronds somewhat deltoid, 3 to $7 \mathrm{in}$. long and broad; rhachis and midrib densely clothed with rather long soft white hairs. Sori scanty on the few fronds gathered.

POLYPODIUM, Linn.

P. australe, Metten.; Hook. Spec. Filic. iv. 167 ; Syn. Filic. 322 ; Fl. Austr. vii. 762.4.

P. fuscopilosum, F.v. M. and Baker in Britt. Journ. Bot. xxv. 163. $2,3,4$.

P. Hookeri, Brackenr.; Hook. Spec. Filic: iv. 171; Syn. Filic. 319 ; Fl. Austr. vii. 763. Black-haired Fern. 2, 3.

P. albosetosum, n. sp. (Name referring to the white bristle-like hairs in the sori.) Rhizome erect or very shortly creeping, the blunt apex covered by broadly ovate, imbricated, light-brown scales. Fronds tufted, ail under 2 in. long and 3 lines broad, tapering from a broad 
obtuse end to very short stipes, which seldom if ever exceed 3 lines in length, hairy throughout with light-coloured fine hairs, those of the stipes short and strigose, those of the frond soft and rather long, and all of a very light colour, nearly white; veins simple or once forked; sori orbicular, with bristle-like white hairs amongst the spore-cases, at the apex of fork of the vein, and forming a single row on each side of the costa on the upper portion of the frond.

Hab. : On rocks and stems of trees, Bellenden-Ker, at an altitude of from 4,000 to 5,000 feet.

This small fern is closely allied to $P$. Hookeri, but separated by the form of the scales, colour of the hairs-which do not form so decided ciliæ to the marginsand general appearance.

P. pallidum, Brackenr.; Fil. U.S. Expl. Exp. 18; Hook. Spec. Filic. iv. 142, 266, t. 269 ; Fl. Austr. vii. 759 . Pale Fern. 1, 7.

P. aspidioides, var. tropica, Bail.; Syn. Queensl. Fl. 714. Shiny F'ern. 7.

P. proliferum, Presl.; Hook. Spec. Filic. v. 13 ; Syn. Filic. 315; Fl. Austr. vii. 765.7 .

P. urophyllum, Wall.; Hook. Spec. Filic. v. 9; Syn. Filic. 314; Fl. Austr. vii. 765. Tailed Fern. 1, 7 .

P. pœcilophlebium, Hook.; Hook. Spec. Filic. v. 14; Syn. Filic. 314; Fl. Austr. vii. $766.1,7$.

P. serpens, Forst.; Hook. and Bak. Syn. Filic. 349 ; Fl. Austr. vii. 767. Creeping Rock Fern. 4.

P. confluens, $R$. Br.; Prod. ; Fl. Austr. vii. 767. Creeping Tongueleaved Fern. 7.

P. acrostichoides, Forst.; Hook. and Bak. Syn. Filic. 350; Fl. Austr. vii. $767.1,7$.

P. simplicissimum, F. v. $M$. Simple-leaved Polypodium. 2, 3,4. P. phymatodes, Linn.; Hook. Spec. Filic. v. 82 ; Syn. Filic. 364; Fl. Austr. vii. 769. Scented Fern. 5.

P. verrucosum, Wall.; Hook. Spec. Filic. v. 31 ; Gard. Ferns, t. 41 ; Syn. Filic. 344; Fl. Austr. vii. 770. Warted Fern. 1.

P. subauriculatum, Blume; Fl. Jav. Filic. 177, t. 83 ; Fl. Austr. vii. $771 . \quad 1,2,3$.

P. rigidulum, Swartz; Hook. and Bak. Syn. Filic. 368 ; Fl. Austr. vii. 771. Rock Fern. 1, 2.

P. quercifolium, Linn.; Hook. Spec. Filic. v. 96 ; Syn. Filic. 367 ;

Fl. Austr. vii. 772. Oak-leaved Fern. 1, 2, 7.

P. irioides, Poir.; Hook. Spec. Fílic. v. 67 ; Syn. Filic. 360 ; Fl. Austr. vii. 771. Flag-leaved Fern. 1, 2, 7.

NOTHOLANA, R. Br.

N. vellea, R. Br.; Prod.; Fl. Austr. vii. 773. Cloak Fern or Woolly Fern. 2,7 .

GRAM MITIS, Swartz.

G. (Selliguea) membranacea, Blume; Fil. Jav. 123, t. 52, f. 2. Rhizome slender, creeping, climbing up the stems of trees by the aid of adventitious roots emitted from the under side, the upper surface densely paleaceous, with rather long dark-brown narrow 
scales. Fronds membranous, somewhat distantly placed on the rhizome, simple or variously lobed, and either form soriferous, glabrous, 6 to 12 in. long, tapering to a rather long stipes and elongated apex, the undivided fronds attaining a width of 2 in. in the widest part, lobes on the divided ones from 1 to 12 , spreading tapering towards the point, but cut down so as to leave but a wing on the costa in the sinus about $\frac{1}{4}$ or $\frac{1}{2}$ in. wide, the segments varying from 1 to 4 in. long; venation rather open, forming large hexagonal areoles containing forked free veinlets; sori in short lines or oblong masses, often not exceeding 2 or 3 lines on the divided fronds, and distant from the costule, but on the entire simple fronds often reaching from near the costa to near the margin, but these lines are frequently interrupted.

Hab. : Bellenden-Ker, at an elevation of 4,000 feet.

The habit of this fern and its variously formed fronds reminds one of Polypodium scandens, Forst., and further, when dry, it possesses the same fragrance as that and some allied Polypodiums. To pteridologists, the meeting of this species, bearing its various forms of foliage, is most interesting, as it saves the mistake being made of multiplying species, and completes the description of an old species. $G$. Sayeri, F. v. M. and Baker, has been named from fronds of this species; and in all probability G. Wrightii, Hook., is but another form. I might here remark that probably Mr. Baker was not far wrong when he placed the Queensland fern, G. ampla, F. v. M., under G. elliptica, for it varies greatly in the form of the fronds. In cultivation, the fronds are much smaller and often entire, and these as frequently bear sori as the more developed deeply lobed ones. On starved plants, indeed, of $G$. ampla, the almost only distinctive mark to separate it from $G$. membranacea is its broad flattish rhizome and a slight difference, perhaps, in the venation.

G. ampla, F. v. M.; Fragm. v. 188 ; Fl. Austr. vii. 777. 1, 2, 7.

\section{ANTROPHY UM, Kaulf.}

A. reticulatum, Kaulf; Hook. Spec. Filic. v. 169 ; Syn. Filic. 393 ; Fl. Austr. vii. 777. Plantain-leaved Fern. 1, 2, 3, 5, 7.

\section{ACROSTICHUM, Linn.}

A. conforme, Swartz; Hook. Spec. Hilic. v. 198 ; Syn. Filic. 401; Fl. Austr. vii. 778. Rock or Deer-tongue Fern. 3, 4 .

A. sorbifolium, var. leptocarpum; Hook. Spec. Filic. v. 241 ; Syn. Filic. 412 ; Fl. Austr. vii. 779. Climbing Fern. 1, 2.

A. repandum, Blıme; Hook. Spec. Filic. v. 260 ; Syn. Filic. 419; Fl. Austr. vii. $779 . \quad 1,2,3$.

A. Taylori, Bail.; Rep. Queensl. Accli. Soc. 1884; First Suppl. Syn. Queensl. Fl. 65. 4.

A. neglectum, Bail.; Proc. Linn. Soc. N.S.W. v. 32; Syn. Queensl. Fl. 722. Frilled Fern. 2, 3, 4, 6.

A. aureum, Linn.; Hook. Spec. Filic. v. 266 ; Syn. Filic. 423 ; I'l. A ustr. vii. 779. Swamp Golden Fern. 5.

A. spicatum, Linn.; Hook. Spec. Filic. v. 280; Syn. Filic. 424; Fl. Austr. vi. 780. Tailed Acrostichum. 1.

PLATYCERIUM, Desv.

P. alicorne, Desv.; Hook. Spec. Filic. v. 282 ; Syn. Filic. 425; Fl. Austr. vii. 780. Elk's-horn. 4.

P. alicorne, var. Hilli, T. Moore; Gard. Chron., July 13, 1878 ; Syn. Queensl. Fl. 724. 7. 


\title{
Z0OLOGY OF BELLENDEN-KER, AS ASCERTAINED BY THE LATE EXPEDITION UNDER MR. A. MESTON.
}

\author{
Queensland Museum, \\ Brisbane, 4th October, 1889.
}

Gentuemen,-There is probably no part of Australia, certainly no part of Queensland, which at present excites the interest of the naturalist so forcibly as the district extending from Cardwell northwards for some distance beyond Cairns and inwards to the western slopes of the Razor-back Range. In this limited tract of coast country we find a concentration of forms of animal life elsewhere (in Australia) unknown. It has peculiar mammals, peculiar birds, peculiar reptiles, molluses, insects, and in many cases these strangers to the rest of the land are derivatives, not from the surrounding Australian stock, but from the Indo-Malayan fauna on the one hand and the Papuan on the other.

The cause of the phenomenon is a problem of much interest in its bearing on the distribution of the lower animals, still more in its probably being an important factor in the history of man. But before attempting its explication it is advisable that we should know as fully as possible the extent to which the peculiarities of this remarkable region are carried. This is an object to which, with your approbation, long and not altogether unsuccessful attention has been paid by your staff.

In pursuance of that object, a proposal to explore Bellenden-Ker, the highest ground in the district, made to the Government by $\mathrm{Mr}$. A. Meston, in the interests of zoology and botany, and promising to yield a valuable increase in our knowledge of the natural productions of the district, having been communicated to me, I ventured to anticipate your approval of Mr. Meston's application for the services of the zoological collector, and despatched Mr. Broadbent to Cairns with instructions to report himself to the leader of the expedition on his arrival.

The expedition left Cairns on the 14th of June, and kept the field ten weeks, returning on the 26th of August. Its results, so far as they pertain to zoology, I have now the honour to report.

Possibly those results are not so plentiful as they might have been had the explorers been able to continue their labours until the summer months. It is, of course, impossible to accept the fruits of two or three months' work at any season, but more especially in the winter season, as representing the total amount of the indigenous life of a region. Birds are apt to seek higher or lower levels as their appropriate food or temperature dictates; reptiles and the rest seek their dormitories till called into activity by greater warmth, moisture, or provender. In estimating the value of the zoological work done during 
this exploration we must therefore take into account the seasonal conditions under which it was accomplished. With this allowance it is by no means unsatisfactory. The general results obtained seem to be-

1st. The establishment of the fact, probable in itself, that at a height of 5,000 feet in the latitude of Bellenden-Ker no change of fauna takes place, even in a district susceptible of the introduction of exotic forms. Not only were some of our most familiar birds, such as the Thickhead (Pachycephala gutturalis), seen in numbers on the top of the mountain, but the more local kinds-for example the Tooth-billed Cat Bird, Meston's Bower Bird, and the new Blackthroated Sericorn-were found at all heights and on the summit, over which were seen flying the Blue-mountain and Scaly-breasted Lorikeets.

2nd. The discovery of two species of lacertian reptiles, both of them additional proofs of the statement previously made that an importation of extra Australian forms of life into this locality has, by some means, been brought about. These lizards can only be referred to the genera Perochirus (belonging to the Geckoes) and Tropidophorus (a genus of Scines) found in Indo-China, Borneo, and the Philippine Islands, and not previously known to extend their range beyond those limits. Under the methodical names of Tropidophorus queenslandia and Perochirus mestoni these lizards have been described in the Proceedings of the Linnæan Society of New South Wales.

3rd. The enrichment of your stores with a considerable number of duplicate specimens, valuable for study or distribution, and with a supply of several species which have hitherto been desiderata. The entire collection consists of-

\begin{tabular}{|c|c|c|c|c|c|c|c|}
\hline Mammals & $\cdots$ & & $\ldots$ & \multicolumn{2}{|c|}{11 specimens, } & \multicolumn{2}{|c|}{8 species } \\
\hline Birds $\quad \ldots$ & $\ldots$ & $\ldots$ & $\ldots$ & 195 & $"$ & 79 & \\
\hline Lizards ... & $\ldots$ & $\ldots$ & $\ldots$ & 15 & $"$ & 9 & $"$ \\
\hline Snakes ... & $\ldots$ & $\ldots$ & $\ldots$ & 8 & ", & 6 & $"$ \\
\hline Molluses & $\ldots$ & $\ldots$ & $\ldots$ & 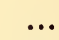 & & 10 & $"$ \\
\hline Insects & $\ldots$ & $\ldots$ & $\ldots$ & 63 & $"$ & 33 & $"$ \\
\hline & & & & tal & .. & 145 & \\
\hline
\end{tabular}

Subjoined is a detailed and, where necessary, descriptive list of all the animals procured or noticed by the explorers.

\section{MAMMALS.}

Aboriginals. Two skulls of the Mulgrave River tribe Charróogin. So few skulls of Queensland natives have been described, that it would be culpable to neglect the present spportunity of recording measurements and characters.

Aduit male skull.-Dolichocephalic, mesognathous, microseme, platyrhine. Length, 180; breadth, 127; height, 133; frontal breadth, maximum 107, median 99.5 ; horizontal circumference 510 , pre-auricular 236; longitudinal dimensions, frontal 125, parietal 125, occipital 108; transverse dimensions, frontal 275 , bregmatic 305, parietal 320; foramen magnum, length 34 , breadth 28 ; orbit, width 42 , height 35 ; nasal orifice, width 
28, height 48; malar height 25, basi-nasal 137; bizygomatic breadth 137; auriculo-orbital length 73, basi-alveolar 106 ; gnathic index $102 \cdot 8$, cephalic $70 \cdot 6$, nasal $58 \cdot 3$, orbital $83 \cdot 3$. Lamboidal suture simple; inion obsolete; zygomata prominent, glabella moderately prominent, convex; epipteric none; sagittal suture depressed; parietal region tectiform. Mandible, symphysial height 29, molar 25, coronoid height 58; goniosymphysial length 71 ; bicondylar width 111 ; bigoniac width 73 . The upper median front tooth absent, its alveolus obsolete.

Adult female skull.-Dolichocephalic, prognathous, microseme, platyrhine. Length, 185; breadth, 126; height, 130 ; frontal breadth, maximum 106, median 98; horizontal circumference 506, pre-auricular 224; longitudinal dimensions, frontal 128, parietal 140, occipital 118; transverse dimensions, frontal 266 , bregmatic 296 , parietal 360 ; foramen magnum, length 35 , breadth 30 ; orbit, width 39 , height 30 ; nasal orifice, width 25 , height 37 ; malar height 22 , basi-nasal 90.5 ; bizygomatic breadth 123 ; auriculo-orbital length, 67, basi-alveolar 94.5 ; gnathic index 105, cephalic $68 \cdot 1$, nasal 70 , orbital 77 . Lamboidal suture simple, two wormian bones on one side; inion not decided; zygomata not prominent; glabella very prominent, overhanging nasion; epipteric none; parietal region subtectiform.

Attention should here be drawn to the great dearth of aboriginal skulls and skeletons in the national museum. From an ethnological point of view they are of the utmost value. They are readily procurable in many localities, yet efforts to obtain them from public officers, and others who have the necessary opportunities, have constantly failed.

Pteropus scapduatus, Pet. Yellow-shouldered Flying-Fox. The range of this bat extends to the Islands of Torres Straits.

Acanthomys Leucopus, $G r$. White-footed Rat. Bellenden-Ker; distributed widely over North Australia.

Hydromys leucogaster, Geo. Water Rat. Russell River ; common in most parts of Australia in several varieties.

Halmaturus agilis, Gld. Red Creek Wallaby. All North Australia as far south as Rockhampton; frequents long grass bordering creeks; easily recognised by its colour, haunts, and generally thrifty condition.

Hatimaturus, $s p$. A Padymelon allied to $H$. thetidis, from which, however, it differs considerably; possibly an undescribed speciesskeleton only.

Dasfurus maculatus, Shaw. Spotted-tailed Native Cat. This, the largest and most destructive of our native cats, attaining sometimes a weight of ten pounds in the neighbourhood of Brisbane, is an object of dread to the natives of the Herberton district; they even accuse it of carrying off their piccaninnies. Exaggerated ideas of it have probably given rise to certain rumours of a great striped carnivore of arboreal habits infesting the Herberton wilds. After prolonged search for the latter in its known haunts nothing but the native cat in question could be found. The Spotted-tail extends from Tasmania to the Cape York Peninsula. 


\section{BIRDS OF WHICH SPECIMENS WERE OBTAINED.}

Falco subsiger, Gr. The Black Falcon. A comparatively rare bird, and very welcome to the museum.

Hirracidea berigora, Vig. et Hors. The Brown Hawk. I find no constant difference of colouring and no real distinction of locality between this and the so-called Eastern Brown Hawk, H. orentalis, Schleg. Birds with the colouring of each and intermediate grades thereof occur all over Queensland, and during this expedition were shot in company on the Mulgrave Plains; the name $H$. orientalis, applied to our Queensland bird, should therefore be allowed to lapse.

Astur nove-hollandiж, $G m$. The White Goshawk. A beautiful bird common throughout Queensland.

A. approximans, $\nabla$. et H. Barred Goshawk. "Common on BellendenKer up to 3,000 feet."-Broadbent. Generally distributed.

Accrpiter cirrhocepiralus, Vieill. Collared Sparrow Hawk. " Shot on the spurs of Mount Sophia; seen on Mount Barnard at 1,800 feet."-Ib. Generally distributed.

Milvus affinis, $G l$. Common Kite. Mulgrave River and foot of Bellenden-Ker; common almost everywhere.

Strix Delicatula, Gld. Australian variety of the "Barn Owl." Mulgrave River.

Ninox connivens, Lath. Winking Owl. 380-feet camp, BellendenKer.

N. LURIDA. In former observations on birds from this district I noticed this little owl as probably a variety of $N$. boobook. From the present and other specimens since obtained I am now persuaded that it should take rank as a distinct species, and therefore append the necessary description. Broadbent remarks that "this is a true mountain bird, found always in dark scrubby gullies. It was heard at Palm Camp, at an elevation of " 400 feet." The museum specimens are from Bellenden-Ker, Sea View Range, the vicinity of Cardwell, and from no other part of the country.

N. LURIDA, n. $s$.

Adult male.-Upper surface of head and neck uniform dark brown, hind neck and back coffee-brown with a few concealed white spots on the lateral and anterior feathers of the mantle. Lower back and upper tail coverts uniform paler brown. Tail with two central feathers uniform, the laterals with four or five distinct or nearly obsolete pale bars on the inner web. Scapulars brown, with one or two large white median spots or bars on one or both webs. Quills externally washed with greyish brown, the outer webs with broad obscure subrufous cross-bars; the inner webs with a few obscure transverse bars, the inner ends of those near the base forming a white spot. Wing coverts uniform brown, a little brighter than on the head. Lores and cheeks anteriorly white, the plumes with black shafts; hinder part of cheeks and ear coverts brown like the head; a supraciliary stripe over the fore part of the orbit white more or less stained with buff. Chin whitish, its median hinder feathers with brown shaft streaks, the laterals buff with brown centre, these forming a line behind the 
ear coverts. Throat rufous brown, obscurely spotted or streaked with buffy white. Breast and abdomen deep rufous brown, largely spotted with white. Under tail coverts with a median spot on both webs, and the tips brown or buffy brown, with one or two white median spots. Under surface of tail pale brown with four or five more or less obsolete pale transverse bars. Axillaries rufous or ochreous. Under wing coverts rufous, edge of wing buffy white or white. Under surface of wing silky brown with the transverse bars of the quills in strong contrast. Legs rufous. Bill white, blackish below the nostrils. Mandible blue-black, yellow at the base. Total length 290, wing 225, tail 137, tarsus 38 .

Adult female.-Like the male, but with the throat and upper breast rich chocolate brown with fulvous stripes. The tail uniform brown above and below, the quills narrowly edged with buffy grey, and the bill black except the basal half of the culmen.

Localities-Herbert Gorge, Bellenden-Ker.

Petrochelidon nigricans, Deill. Martin. Mulgrave River.

Collocalia spodiopygia, Peale. Little Swift. North-eastern Queensland, New Guinea, \&c. "Common at the base of Bellenden-Ker, and up to 1,800 feet: I have seen it catching flies till near dark, and then fly towards the mountain; it breeds in the rocky gorges of the coast range from the Herbert River to above Cairns." Broadbent.

Merops ornatus, Lath. Bee-eater. Bellenden-Ker to 4,000 feet; commonly distributed.

DaCelo LeaChit, $V$. et $\mathbb{H}$. Blue-rumped Kingfisher. Mulgrave River.

Halcyon macleayi, J. et $S$. Common Bush Kingfisher. Generally distributed.

$H$. saxctus, $V$, et $H$. Sacred Kingfisher. Generally distributed.

Artamos leucogaster, $\overline{V a l}$. White-rumped Wood Swallow. A pretty common and widely spread bird.

Strepera graculina, Wht. Pied Crow Shrike. On Bellenden-Ker to 1,800 feet; all through Eastern Queensland.

Cracticus rufescens, De Vis. Brown Crow Shrike. Confined to the district; on Bellenden-Ker to 1,800 feet.

C. Quori, Less. Black Crow Shrike. North-eastern Queensland and New Guinea, Bellenden-Ker to 3,000 feet.

Graucalus lineatus, Swain. Swainson's Graukle. Bellenden-Ker, Mulgrave and Russell Rivers.

G. Mentalis, $\boldsymbol{V}$. et $\boldsymbol{H}$. Varied Graukle. Common, widely spread.

LALAGE kARU, Less. Red-vented Shrikeling. Fairly common and distributed.

L. TRICOLOR, Swain. White-shouIdered Shrikeling. Common, widely spread.

Pachycephata gutturalis, Lath. Yellow-bellied Thickhead. Common in scrubs throughout Queensland, to summit of BellendenKer in number.

P. RUfiventris, Lath. Red-bellied Thickhead. Common in forests everywhere, on Mount Barnard to 1,800 feet. 
Colmuricincla boweri, Ram. Hissing Shrike Thrush. Peculiar to this district, in which it is a common mountain bird. Obtained on Sea View Range, in the Herberton scrubs, and on Bellenden-Ker at 4,000 feet.

C. RUfraster, Gld. Rust-breasted Shrike Thrush. Common; Bellenden-Ker, at 3,000 feet.

Dicruropsis Bracteata, Gld. Drongo Shrike. Mr. Broadbent notes a few stationary in the Mulgrave scrubs as exceptions to the migratory habits of this bird.

Rmipidura albiscapa, Gld. White-shafted Fantail. Common in forests of Eastern Queensland, frequent at 4,000 feet on Bellenden-Ker, and seen on the summit.

R. RUFIfrons, Lath. Red-fronted Fantail. Frequent in scrubs east and north; on Bellenden-Ker at 4,000 feet.

ARses KaUPI, Gld. Kaup's Flycatcher. North-eastern coast to Cape York; not infrequent on the mountain to 2,000 feet.

Miagra RUbecula, Lath. Lead-coloured Flycatcher. Eastern districts to Cape York; common in scrubs.

Piezorhynchus nitidus, Gld. Glossy Flycatcher. Russell River, Cape York, \&c.

P. Gouldir, Gr. Black-fronted Flycatcher. Mulgrave River.

Gerigone flatida, Ram. Yellow Gerygon. Foot of Bellenden-Ker. Known from the Herberton district only.

Pecilodryas capito, Gld. Large-headed Robin. On the summit of Bellenden-Ker. Common at all levels and in the Mulgrave scrubs.

Eopsaltria inornata, Ram. Plain-coloured Robin. Mulgrave River. The vadility of this species has been denied without sufficient cause.

Malurus amabilis, Gld. Lovely Blue Wren. Bellenden-Ker, at 1,800 feet.

M. dorsalis, Lewin. Crimson-back Wren.

Sericornis gutruralis, De Vis. Black-throated Sericorn. A male example of the Sericorn, lately described (Pro. Roy. Soc. of Queens., 1889) from a female specimen taken at Herberton a few months ago by Mr. Broadbent. "This bird inhabits the high peak of Bellenden-Ker; shot specimen at 5,000 feet."-Broadbent.

Acanthiza pusilua, Lath. Little Thornbill. Bellenden-Ker.

Pitma strepitans similuima, Gld. Northern Pitta. Beyond diminished size, this bird has no claim to recognition as a distinct species, and where it occurs, as in this and other localities, mingled with birds of normal size, it is even difficult to rank it as a variety.

Ailuradus maculosus, Ram. Spotted Cat Bird. Common on Bellenden-Ker at 3,400 feet.

Scenupeus Dentrostris, Ram. Tooth-billed Cat Bird. "This is a true mountain bird, not or seldom found in low scrubs. Specimen shot at 4,000 feet." - Broadbent. 
Prionodura newtontana, De Vis. Meston's Bower Bird. Found at all heights to the summit of Bellenden-Ker and in the scrubs around Herberton at a high elevation. In connection with the bower of this handsome bird we are indebted for an interesting fact to Broadbent's observation, that whereas towards the base of the mountain the bowers have the elaborate formation noticed lately in the Proceedings of the Royal Society of Queensland, at higher levels they gradually lose their distinctive character, and at the top are reduced to the simple trough-like form of the bower of the Regent and Satin birds, for which they might be mistaken were those birds inhabitants of the district. There is reason to believe that Mr. Meston has acquainted us with the nest and egg of this bird. While hearkening to the call of a male he noticed a rustling in a bush by his side, and looking in saw a bird which he says, without hesitation, was the female just disturbed from a nest built in a fork of the bush. The nest in question is cup-shaped, and loosely constructed of fibrous roots, lined with finer material of the same kind and decorated with a little green moss on the outer side. The egg is $27 \mathrm{~mm}$. long, $9 \mathrm{~mm}$. broad, pale yellowish-grey, profusely freckled and blotched with pale brown.

OrIoLUs VIRIDIs, Lath. Green Oriole. There is no sufficient difference between birds of the northern and southern parts of Queensland to persuado us to adopt for the former Gould's name of $O$. affinis. Mount Barnard at 1,800 feet.

O. Flavocinctus, King. Crescent-marked Oriole. Russell and Mulgrave Rivers. This oriole is found in New Guinea, but no specimens have been received from other parts of Queensland than the Herberton district.

Sphecotheres flaviventris, Gld. Yellow-bellied Fig Bird. Foot of Bellenden-Ker. To this, also, the preceding remark applies, as well as to the two following.

Calornis metalitica, Fem. Starlet. Mulgrave River.

Prilotis gracilis, Gld. Yellow-gaped Honey-eater. Common on Bellenden-Ker, at all heights to 4,000 feet.

P. Macleayara, Ram. Macleay's Honey-eater. Bellenden-Ker, at 4,000 feet. A local bird.

P. frenata, Ram. Bridled Honey-eater. Common on the South Peak at all levels to 5,000 feet; also a local species.

Phillemon buceroides, Swain. Helmeted Friar Bird. Mulgrave River. Extends to Cape York.

Acanthorhynchus tenuirostris, Lath. Spinebill. Bellenden-Ker to its summit. Common from Brisbane northwards.

Mrzomela obscura, Gld. Shy Honey-eater. Bellenden-Ker. Cape York to New Guinea.

Melithreptus albogularis, Gld. White-throated Honey-eater. Bellenden-Ker. Common from Brisbane to Cape York and New Guinea.

Diceum Hirundinacedm, Shaw. Fruit Swallow. Bellenden-Ker at 1,800 feet; generally distributed. 
Zosterops westernensis, $Q$. et $G$. Yellow-throated White-eye. Bellenden-Ker. Occurs also at Chinchilla.

Ptilorhis victorim, Gld. Victoria Rifle Bird. Peculiar to district; on Bellenden-Ker at 3,000 feet.

Ontmonxx spaldixat, Ram. Spalding's Orthonyx. Peculiar to district; common on Bellenden-Ker at all levels to the summit.

Sitella striata, Gld. Streaked Creeper. Bellenden-Ker at 3,800 feet; peculiar to district.

Centropus phasianus, Lath. Swamp Pheasant. Russell and Mulgrave Rivers. Common everywhere.

Cacattia galerita, Lath. White Cockatoo. Bellenden-Ker, 4,000 feet. Common throughout Queensland.

Caliptorhynchus banksir, Lath. Banks's Black Cockatoo. Common on grassy spurs of Mount Barnard at 1,800 feet.

C. stellatus, Wagn. Great-billed Black Cockatoo. On BellendenKer.

Aprosmictos scapulatus, Bechs. King Lory. Common. BellendenKer.

Platxcencus pennantir, Lath. Pennant's Parrakeet. On summit of Bellenden-Ker.

Trichoglossus nove-Holdandie, $G m$. Blue Mountain Lorikeet. Summit of mountain.

T. chlorolepidotus, Kuhl. Scaly-breasted Lorikeet. In flocks on the summit.

Crclopsitta macleayana, Ram. Macleay's Lorikeet. Russell River; peculiar to the district.

Mzigaloprepia magnifica, Temm. Fruit Pigeon. Bellenden-Ker. Common at 3,000 feet.

Chalcophaps longirostris, Gld. Long-billed Green Pigeon. Frequent in Russell and Mulgrave Scrubs. The propriety of separating this from the common green pigeon is very doubtful.

Talegallus lathami, Gr. Scrub Turkey. Bellenden-Ker, at 3,000 feet. Common and general.

Megapodius tumulus, Gld. Megapode. Bellenden-Ker, at 3,000 feet. All north-eastern coast.

Casuarius aUstralis, Wall. Cassowary. The southern half of the eastern coast from Cardwell northwards is the home of this noble bird. The female is occasionally entirely devoid of wattles.

Cuicnemus gradiarius, Lath. Stone Plover. Mulgrave River. Common and generally distributed.

Egralitis nigrifrons, Cuv. Black-fronted Dottrell. Mulgrave River. Generally distributed, common.

CarPHibIs spinicoldis, Jam. Straw-necked Ibis. Mulgrave River.

Nrcticonax caledonicus, Lath. Nankeen Night Heron. BellendenKer, at 4,000 feet. Common and general. 
BIRDS OBSERVED ON BELLENDEN-KER BY MR. BROADBENT, BUT NOT OBTAINED.

Lophoictinia isura, Gld. Square-tailed Kite. Base of BellendenKer.

Dacelo gigas, Bodd. Common Laughing Jackass. Bellonden-Ker, to 2,000 feet.

Tanysiptera syutia, Gld. Racquet-tailed Kingfisher. "Nest in termite nests seen at 1,800 feet; lay four white eggs, and feed their young with termites." - Broadbent.

Pardalotus punctatus, Temm. Spotted Diamond Bird. On grassy spurs from 380 to 1,800 feet on Bellenden-Ker.

Gradcalus melanops, Lath. Black-faced Shrike. Common on Mount Barnard at 1,800 feet.

Colluricincla irarmonica, Gld. Piping Shrike Thrush. BellendenKer, at 2,000 feet.

Micreca Flavigastra, Gld. Yellow-bellied Flycatcher. Mount Barnard, at 1,800 feet.

Heteromyias cinereifrons, Ram. Grey-fronted Robin. Common on Bellenden-Ker at 4,000 feet.

Eopsaltria acstralis, Lath. Yellow Ścrub Robin. Bellenden-Ker, at 4,000 feet.

Psophodes crepitans, $V$. et $H$. Coach-whip Bird. Top of BellendenKer.

Sericoris cimreogularis, Gld. Yellow-throated Sericorn. BellendenKer, at 3,000 feet.

CEgrntha temporalis, Lath. Red-browed Finch. Foot of the mountain.

Mrzomela sanguinolenta, Lath. Blood Bird. Foot of the mountain.

Zosterops carulescens, Lath. White-eye. Foot of the mountain.

Chimacteris Ledcopmes, Lath. White-throated Tree Creeper. Common at 4,000 feet on Bellenden-Ker.

Cacomantis tymbonomes, Mill. Northern Cuckoo. Seen at 3,000 feet.

Carpophaga norfolciensis, Lath. White-headed pigeon. This was seen by Mr. Meston in hundreds on South Peak at 5,000 feet, nesting in the tops of tree-ferns. Common in the Mulgrave and Russell River scrubs.

Lophaimus antarcticus, Shaw. Topknot Pigeon. At foot of Bellenden-Ker.

Macropygia pirasianelua, Temm. Pheasant Pigeon. Common on the mountain up to 3,000 feet.

The comparative scarcity of birds shown by the preceding lists is due, in Mr. Broadbent's opinion, to the absence of the migratory birds frequenting the mountain in summer; to the intense cold experienced on the higher slopes, driving many of the tenderer kinds to the shelter of the gullies at the foot of the mountain; and to the prevalence of rain and cloud during the period of exploration. 
LIZARDS.

Geckoes-Geckonida.

Heteronota eboracensis, Macl. A small pimpled Ground Lizard, previously known only from Cape York and Herberton; quite harmless, though dreaded by the blacks.

Gemryra variegata, Dum. et Bibr. Common, and generally distributed.

Perochirus mestoni, De Vis. Unique and valuable.

\section{Agamidae.}

Gonyocephatus boydi, Macl. A crested tree lizard peculiar to the district.

Physignathus lesuedrit, $G r$. The common Creek Lizard.

Mocoa challengeri, Blgr.

Scrncs-Scincida.

Heteropus rhomboidalis, Pet. Found also at Mackay.

Tropidophorus quennsuandie, $D e$ Vis. Unique and valuable.

SNAKES.

Constrictors-Boidoe.

Liasis olivacea, Gr. Rock Snake.

L. Amethystinus, Schn. This and the preceding are harmless rock snakes, ranging over North Australia, New Guinea, and neighbouring islands.

Morelia variegata, $G r$. The common Carpet Snake.

HarmLess-Colubrida.

Herbertopirs plumbeus, Macl. Herbert River Snake. A nocturnal snake peculiar to the Herberton district, in which it is common, and generally reputed to be poisonous. As under this impression fatal results have followed from its bite, it is important that the error should be corrected. The snake has all the characteristics of a perfectly harmless reptile.

\section{Poisonous-Elapidae.}

Hoplocephadus nigrostriatus, Krft. Black-striped Snake. A small red snake, scarcely dangerous.

Acanthophis antarctica, Wagl. The common Death Adder. All Australia and New Guinea.

\section{MOLLUSCA.}

The following report on the snails procured is supplied by Mr. Hedley :-

"Sir,-I beg to furnish you with the following report upon the Terrestrial Mollusca collected during the recent ascent of Mount Bellenden-Ker. Among them I find a Nanina and a Helix which do not agree with any published description of Queensland shells, and which I am obliged to consider as new. The remainder contains several rarities, the animals of which have never been examined. I have 
therefore availed myself of the opportunity of dissecting and making drawings of the most important features.

"The collection consists of-

Rhytida sheridani, Brazier. R. franklandiensis, Forbes. Nanina, $n . s p$.

Helicarion brazieri, Cox. Helix, $n . s p$.

Helix bipartita, Ferrusac.

H. bellenden-kerensis, Brazier.

H. macgillivrayi, Forbes.

Aneitea graeffei, Humbert.

Dermatocera vitrea, Lesson.

"I have, \&c.,

$$
\text { "CHARLES HEDLEY." }
$$

\section{INSECTA.}

Mr. II. Tryon reports as under on the insects submitted to him for identification :-

\section{Lepidoptera.}

\section{Rhopalocera.}

Papilionida-Papilio egipius, Misk. $\quad \ldots \quad$... 1 damaged.

Pierida-Delias mysis, Fabr. $\quad \ldots \quad \ldots \quad \ldots \quad \ldots \quad 5 \quad$,

Nymphatida-Cethosia cydippe, Linn. $\quad \ldots \quad 1 \quad$ ",

Satyrida-Mycalesis terminus, Fabr. ... $\quad \ldots \quad 1$ ",

Cœnonympha infuscata, Macl. $\quad$... 11 ",

Hesperida-Apaustus agraulia, Hew... $\quad . .61$,

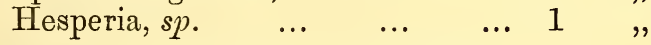

Summary -7 species, 11 specimens.

Norr. - This collection, which was obtained on the Mulgrave River, includes four of the seventeen species already known as occurring in the vicinity of Mount Bellenden-Ker.

\section{Heterocera.}

Bombyces.-Doratifera, $s p . \quad \ldots \quad \ldots \quad \ldots \quad 1$ specimen.

Zyganida._*Hydrusa bicolor, Walk. $\quad$.. 1 "

Lithosiidce.-Hypsa dama, Fabr. $\quad \ldots \quad \ldots \quad$... 2 ",

" Deiopeia pulchella, Linn. $\quad \ldots \quad 5 \quad$,

Arctiidae.-Aloa marginata, Moore $\quad . . \quad \ldots \quad$... 1 specimen.

Noctuida. -Trigonodes hypassia, Cram. $\quad \ldots \quad 1 \quad$ "damaged.

" Acantholipes (trifasciata, Moore) ... $6 \quad 6 \quad "$

" Hulodes (caranea, Cram.) ... $\quad \ldots{ }^{\prime} \quad 1 \quad$ ",

$\begin{array}{cccccc}\text { Gonitis, } s p . . . & \ldots & \ldots & \ldots & 1 & \end{array}$

Pyralida.-*Siriocauta testulalis, Hubn., var.... 1 "

" *Conchylodes caberalis, Guen. ... 1 "

" Zinckenia recurvalis, Fabr. ‥ 1 ",

" Acharana otreusalis, Walk. $\quad \ldots .99 \%$,

" *Phakellura indica, Saund. $\quad$... 1 1 "

, Pachyarches (pomonalis, Guen.) ... 1 ,"

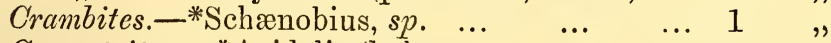

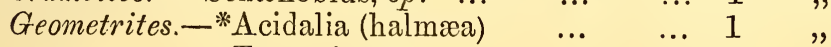

", *Taxeotis, $s p$.

Summary-19 species, 37 specimens (many damaged).

Notr.-Those marked * have been obligingly identified by Dr. T. P. Lucas. All were collected on the Mulgrave River at the foot of Mount Bellenden-Ker. Most of the species are common and have a wide range of occurrence. 
Coleoptera.

Carabida.-Pamborus viridis, Gory $\quad \ldots \quad \ldots \quad 2$ specimens.

Lucanida.-Aulacocyclus edentulus, W.S.M.... 1 "

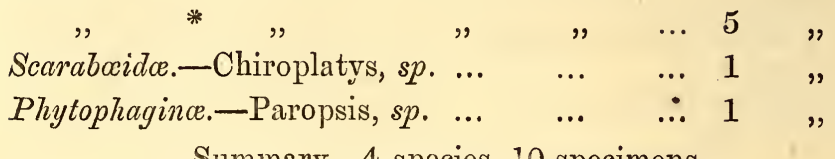

Summary-4 species, 10 specimens.

NотE.-With the exception of *, which were collected on the Mulgrave River, the other beetles were obtained on Mount Bellenden-Ker at an altitude of 4,000 feet.

In addition to the above, the Colonial Botanist obtained forty beetles during the progress of the expedition. They were forwarded by him to the Rev. T. Blackburn, B.A., who states that, like the above, they are most of them common North Australian forms. Albeit he has detected a new species of Chilocorus amongst them. This ladybird is interesting as being the only new insect obtained during the expedition.

\section{Mrscellanea.}

The expedition also obtained three young cockroaches (Panthesia, sp.), one scorpion (Hormurus caudiculus), one Sphcrotherium, and one Julus.

I have, \&c.,

\section{HENRY TRYON,} Assistant Curator.

C. W. De VIS,

To the Board of Trustees.

Curator. 


\title{
THE BELLENDEN-KER EXPEDITION.
}

By A. Meston.

\author{
[Extracted from the "Courier."]
}

THE following is the preliminary chapter of an account of the first expedition of the kind ever sent out in Australia by any Australian Government. Those who by some artless process of reasoning, or more likely by an abrupt arrival at a conclusion without the assistance of any reason whatever, conceived an idea that the expedition was a picnic excursion-one prolonged holiday of calm, ecstatic, sensuous joy -will be required to part from that idea, with or without a pang. When the attention of the Colonial Secretary was called to the desirableness of Queensland obtaining the first knowledge of her own scientific resources, and my own services were offered gratuitously as the leader of a scientific party, Mr. Morehead remarked at once that the proposal commanded his earnest approval, and the whole preliminary business, so far as he was concerned, was settled in ten minutes; while, in the Lands Office, Mr. Black displayed an equally admirable decision. Mr. Bailey and myself left Brisbane on board the "Elamang" on the 4th June. We arrived at Cairns on the 9th, and were met there by Mr. Kendall Broadbent, the museum zoological collector, who had come down from the Herberton Ranges to join the expedition. In three days all preliminary preparations were completed, and we started on the 14th from Cairns. The party consisted of Mr. F. M. Bailey, colonial botanist; Mr. Broadbent, the ornithologist; my fourteen-year-old son Harold; a colonial experience young man named Walter Beman, sent out to me from Yorkshire; four Tanna Island kanakas; and myself. All the tinware and cooking utensils used by the expeditionary force were specially made for the occasion. There was one small ordinary tent for Mr. Broadbent; oilcloth and canvas to make a camp for the "boys;" and for the rest a large bell-shaped military tent, for which we were indebted to the considerate courtesy of Colonel French, who kindly sent it up from Townsville. With the exception of Mr. Broadbent's gun, all the firearms were supplied by myself free of cost to the Government. They included a double No. 20 choke-bore, by Adams; a double No. 12 choke-bore first-class Hollis; a sporting Snider rifle; and a single No. 12 choke-bore Greener, generously presented by Gartside and Son. Here, also, I would mention the graceful and appropriate present of a handsome rug and complete waterproof suit from Mr. Thomas Finney, of Finney, Isles, and Co. Besides large and small tomahawks, there were six cane knives for cutting tracks. These knives are made by Diston and Son, the famous saw-makers, out of the finest steel, and are the best instruments known for scrub work. The blade is 14 inches long by 4 inches wide at the end, narrowing to $2 \frac{1}{4}$ inches at the handle, which is $\gamma$ inches long. They weigh only a little over $1 \mathrm{lb}$., are practically unbreakable, and will stand an incredible amount of work. Sir William Macgregor told me he found a brass-handled French cutlass the most effective article on the Owen Stanley Range, but no species of cutlass can rival these cane knives 
in traversing dense vegetation. The hook on the back, used for stripping cane leaves, requires cutting off, as it catches in the vines and branches.

Among the outfit was a liberal supply of sand shoes for all hands, kanakas included. No human bare foot will stand long in the country we were in, when the owner is ascending and descending with heavy loads. The sand shoe, or tennis shoe, with the grooved indiarubber sole, is by far the best for rough mountain country. Ordinary boots are unsuitable, uncomfortable, and dangerous. The weakness of the sand shoe is its inferior material. Occasionally, in very rough places, one pair barely lasted the whole day. Sometimes they held out for four or five days. They are only unsafe when the sole is wet, on wet slippery rocks. In that case nothing will hold like the bare foot; but the bare foot requires a prolonged practical experience before frisking at ease through lawyer scrub and over weather-worn granite rocks. That experience my own "mendowies" had thoroughly acquired. Constant wearing of boots is one of the most unhealthy and detestable ordeals to which civilised man is subjected by a blind-eyed mule-headed custom, which has no more reason for this outrage than a stall-fed Calabar fashionable female for covering the abnormal calves of her legs with brass rings, or a Papuan monarch for wearing a sea-shell through the end of his nose. The civilised man still remains in some respects a magnificent specimen of the human ass. He wears a closefitting hat that excludes the sunlight from his stupid head, and is surprised-in the same intellectual fashion as an owl that has lost his tail-to find himself prematurely bald at an early age. He jams his flat feet into tight boots that put a damper on the circulation, and then goes off to consult his doctor, under whose intelligent and disinterested advice he empties a large consignment of assorted drugs into his indignant stomach to cure the headaches and heart disease, and other infirmities which are but the earnest expostulations outraged Nature is making against the tight-boot wearing atrocity.

Having greatly relieved myself by these philosophic remarks, it is time to mention the overwhelming sense of responsibility thrown on me by undertaking to escort the Colonial Botanist to the summit of Bellenden-Ker, and bring him back right side up with every possible care.

Mr. Bailey was described to me as a man never known to quail in danger's stormy hour if there was the remotest prospect of running against a new plant, falling over a log of unknown timber, or treading on some giant species of previously unclassified mushroom. Too well I knew that he was loaded to the muzzle with a full charge of botanical names before which the bravest man would quail, and sensitive vegetation curl up like a pumpkin leaf in a sharp frost. Having effected an insurance on his life for half-a-million, and made a will bestowing sixteen tons of dead and dried plants on anybody who would cart them home, he boldly announced to his anxious friends that he was now prepared to face the land where the Bullophyllum Baileyi was one of the champion orchids, where the Ophyoglossum pendulum and Dendrobium hispidum adorned the noblest trees, and the shy Pogonatherum saccharoideum peeped bashfully from the crevices of the granite rocks. Little was known of Mr. Bailey's endurance and dauntless spirit by those who prophesied that he would never reach 
the top of Bellenden-Ker, that if he did arrive there he would never come back, and in any case would be carried off by a tree-climbing kangaroo, perish dismally of jungle fever, or fall over one of the loftiest precipices and remain for ever tombless and epitaphless, in that lone solitude where mosquitoes cease from troubling and scrub hens are never at rest. These prophets of imaginary disaster will do well to follow the example of the Hibernian prisoner who was unable to say if he was guilty until he had heard the evidence. On the 15th we arrived on the edge of the Mulgrave Plains on the bank of Behana Creek, called "Tringilburra" by the blacks, and camped there beneath the evening shadows of the Walsh Pyramid-"Charrogin" of the mvalls-and near the end of the north spurs of Bellenden-Ker. This name, Bellenden-Ker, was given to the mountain in 1803 by Captain Flinders, in honour of T. Bellenden-Ker, a botanist of the period. The blacks call it Woo-roo-noo-ran (Wooroonooran), spoken slowly with equal accent on all the syllables. Mount Bartle Frere they call "Chooreechillum," and these grand sonorous and euphonious aboriginal names ought to supersede the meaningless Bartle Frere and Bellenden-Ker, given presumably in honour of two gentlemen who had as much connection with these two mountains as with the building of the Pyramids. The native names of mountains, rivers, streams and lakes ought to be jealously preserved in all cases. They are far more appropriate than any we could possibly bestow, and as a rule much more pleasant to the ear. They are also nearly always significant of some peculiarity in the locality. Names like "Chicka-ringa-dingadee" and "Gidgee-gidgee-bar," when repeated slowly, correspond in a remarkable manner with the sound of the waterfalls to which they are applied. And in their names of birds and animals they display the same unison of name and object frequently in a very happy manner, but this is a subject requiring a special chapter.

On the 16th Senior-constable Whelan came over from the police camp on the Mulgrave, bringing four troopers and pack horses to remove the camp to the bank of Tringilburra Creek, at the foot of Mount Toressa. Mr. Commissioner Seymour had very kindly instructed Whelan to afford us any possible assistance not positively interfering with his official duties, and Whelan is certainly entitled to honourable mention and grateful thanks for his kindness and valuable services to the expedition from time to time when his official duties enabled him to join us.

In the afternoon of the 16th we arrived at the foot of Mount Toressa, on the bank of a splendid creek, containing a large stream of delightfully cool, pure water, running furiously over and between confused masses of granite boulders. Here and there were deep, still pools, forming beautiful natural baths, cut clean out of the solid rock. The camp here was to be our base of supplies during the whole time on the Bellenden-Ker Range. We were at the head of a narrow valley, with Toressa (2,600 feet) on one side and the Coast Range (over 3,000 feet) on the other. This was the last point to which the horses could be taken, all beyond being only accessible on foot.

When the horses were unloaded and the camps fixed we went down to the creek to bathe. While seated on a rock in the middle in Adamite costume, there was a wild splash in the pool below me, and there rose to the surface a mysterious form that might be either 
Neptune or the bunyip! Immortal powers! It had the same effect on me as the spirit that appeared to Job.
"Along my bones the creeping flesh did quake, And as my damp hair stiffened thus it spake,
"Behold the Colonial Botanist!'"

And then there came another splash, and the museum zoologist rose from the depths and briefly remarked, "Hooray!"

This was the first appearance of the scientists in their great back action double splash natatorial feats, and certainly the agility they displayed and the observations they made, and the hilarious levity of their general proceedings, seemed to be a truly sublime performance by gentlemen of their regular habits and usually grave and reverend demeanour. But the glories of that bath were enough to send any man into temporary oblivion of all but his own delight.

About sunset we had supper. There was no regular cook in the camp, the bulk of the cooking all through the expedition falling to my share, ably assisted by Mr. Bailey during the manufacture of porridge. I believe he had already a dark suspicion that he was to be fed on porridge all through the trip. Whether this arose from his knowledge of Caledonian habits, or was caused by a sight of the formidable array of bags of oatmeal in camp, is a question not yet fully explained.

Next morning we had breakfast at 7 o'clock, Mr. Bailey personally superintending the porridge, which he stirred with a stick cut from an adjoining Eucalyptus corymbosa. Previous to this trip I would have called it bloodwood.

Then came the adjustment of packs and the selection of all things most urgently required. Each boy took about $50 \mathrm{lb}$., Whelan and myself carrying $4.0 \mathrm{lb}$. besides our guns and ammunition. Mr. Broadbent and Harold also took their share, and Mr. Bailey carried a handbag and his specimen satchel.

On a lovely morning we crossed the creek and started up the long, grass-covered, lightly-timbered slopes of Barnard's Spur, all the peaks of Wooroonooran rising ahead outlined against the clear blue sky, Sophia on the left, and the Main Range on the right. From the crest of Barnard's Spur we looked down on either side into deep, dark, scrub-covered ravines.

Below us on the right roared the long row of splendid falls down the gorge where Tringilburra Creek descends 700 feet in a mile. Away to the north was the inlet country, and Cairns nestling white and silent on the shores of the blue Pacific. At noon we reach the summit at 1,700 feet. Here is the site of an old blacks' camp that must have sheltered a hundred. It gives a splendid view of all Wooroonooran with Chooreechillum rising away towards the south. It formed a lookout station as well as a camp, and was evidently a favourite place of residence. What scenes had been witnessed in the old days by the beautiful trees that stand around that camp and look down into it with their green faces, in voiceless silence! Here was the last of the open forest country. We were to be hidden away in thick tropical jungle until we returned to this point of our journey.

We descended on an old blacks' track through dense scrub down 700 feet on a very deep descent into the junction of the two creeks at the Whelanian Pools. 
This was the site chosen for our second base of supplies, between the first camp and the top of the mountain. The tents were erected on the bare granite rocks, on each side a glorious stream rushing madly down the gorge, and lost in the curving vista far below. Overhead all round towered the tall steep mountains, covered by magnificent vegetation.

The intention was to allow Mr. Bailey and Mr. Broadbent to collect here for a couple of days before starting up the mountain, and to enable the boys to bring up more supplies from the lower camp. The first night here was the first and last occasion on which I attempted to compose a poem.

It was written in emulation of that heroic youth who carried the excelsior banner among the Alpine avalanches.

The influence of the companionship of the Colonial Botanist will be traced here and there by the observant reader.

The shades of night were falling fast,

As o'er the mountain summit passed

A botanist man, extremely nice,

Who bore a plant with strange device,

"Dendrobium hispidum."

His brow was stern, his beard below

Looked white as the Antarctic snow,

And like a silver bugle rung

That weirdly scientific tongue,

"Pogonatherum saccharoideum."

In tall old trees he saw the bright

Orchidian blossoms, pink and white,

Above the spectral mosses shone,

And from his lips escaped a groan,

"Bulbophyllum purpurascens."

"Try not to climb," the young man said,

"Beware the loose rocks overhead;

That granite creek is deep and wide."

But loud that fearless voice replied,

"Polypodium subauriculatum."

"Oh stay," the leader said, " and rest

A half-hour on this turkey's nest ;"

A tear stole slowly from his eye,

But still he answered with a sigh,

"Acrostichum neglectum."

"Beware of every snake you see,

Beware the awful stinging tree,

Beware where cryptogams you seek,"

A voice replied across the creek,

"Alsophila Rebeccæ."

At midday there as in the shade

The pious men of that brigade

Uttered a brief impromptu prayer,

A voice called through the startled air,

"Hymenophyllum javanicum."

A botanist in the evening fog

Was found beside a bean-tree $\log$,

Still grasping like a patent vice,

A plant which bore the strange device

"Bulbophyllum nematopodum."

There in the twilight cold and gray

So peacefully serene he lay,

But at this stage-if not before-

Two wild-eyed men with axes swore,

"We'll kill you, Bailey !"

From this stage henceforward the reader will find we had other work than poetry to meditate upon, and heights to climb far above Parnassus and the Heliconian Spring. 
No. II.

At the Whelanian Pools we remained two days, during which we were out in all directions on the surrounding spurs. Whelan and myself went up the creek towards Bartle Frere, a wild and beautiful glen, where the water comes down in small cascades, with deep clear pools between, and lovely ferns and flowering orchids growing everywhere in glorious profusion. The reader will have some idea of the variety of ferns on Bellenden-Ker when told that Mr. Bailey met with and collected specimens of 112 distinct species! All the way up this creek were fresh camps of the myalls, small temporary dwellings in the usual segment of a dome shape, bent boughs covered by fern leaves or the fronds of the lawyer palm. But the wild children of the mountains had received intimation of the approach of the expedition, for such a mighty host walked not in silence through the lonely scrubs any more than Lucifer's army through the aff righted Deep, and they had tucked up their legs like the A rabs and silently slithered away, as the poet sweetly remarks in his usual high-souled regard for the eternal unfitness of things. Doubtless they were cautiously watching us on some commanding eminence from whence they could emigrate, if necessary, in the fastest time on record. In all the camps were heaps of nutshells or nuts unbroken. In none of them was there a bone of any kind. Throughout the expedition I saw at least a hundred camps, and not a bone visible except the shoulder-blade of a horse on the summit of Barnard's Spur. After eating small animals or birds they probably throw the small bones in the fire and fling the others into the scrub. On the second day Whelan and Broadbent went up the same creek, Bailey was over in the dark fern gully, and $I$ ascended the left-hand creek that came from the centre defiles of Bellenden-Ker. The costume worn by Whelan and myself consisted solely of a close-fitting flannel, with sleeves down to the wrist, a pair of elastic merino drawers, and light sand shoes with grooved gutta-percha soles. In the rocky beds of the creeks we usually walked barefooted, even the sand shoe not being trusted where a slip of the foot might mean certain death. It is quite impossible to give any picture of the savage grandeur of these two creeks, when you ascend to where they are falling in magnificent cascades from the summits of overhanging rocks, descending in a hundred streams down the smooth faces of dark cliffs, rushing with thunder-tones through caverned rocks, or circling in the centre of immense circular cauldrons cut from the solid granite. And everywhere beautiful mosses and ferns, parasites and epiphytes, and creeping and climbing plants scattered profusely, as if nature had wantonly run riot in the uncontrollable madness of floral luxuriance. Beside the camp at the Pools was a perfect natural bath in the solid rock, about 100 feet long, 20 feet wide, and 10 feet deep. The water entered by a cascade at one end and left it by a cascade at the other. About 600 yards below the camp, down the main creek, a large stream entered on the east side, descending from the dark scrub on the face of the Main Range. It fell clear from the face of a rock 100 feet into a deep pool below. I managed to climb up on one side of this fall and reach the summit. Standing on a small plateau of rock across which the stream ran to the edge of the precipice, $I$ beheld a scene that cast summarily into the shade all ever witnessed of similar magnitude. At my feet was a dark unfathomable pool between two walls of tall polished cliffs, like 
the entrance to some rock temple of the giants. They stood 50 feet high and 20 feet apart. Into the pool between these pillars fell a splendid cascade about 50 feet in height. Beyond that rose seven others, all of similar altitude, rising one above: the other through the long contracting vista, until the last one looked like a sheet of glittering snow in the remote end far up the side of the mountain, the whole forming what I have described in my official report as one silver flashing sublime staircase of descending waters. I stood entranced in the presence of this magnificent and wonderful scene, that rivals in its living reality all that Romance, the "parent of golden dreams," ever pictured in the fancy of the poet and the painter. To this scene I have given the name of the "Morehead Cataracts," in honour of the Premier of a Government who sent out the first purely Australian Scientific Expedition.

Below this scene, in the main creek which descends 700 feet in a mile, are the Francesca Falls-cataract above cataract, from 50 feet to 200 feet in height, a spectacle over which the artists and poets and landscape photographers of the future will rave in all the delirious ecstacy of art and sandwiches, poetry and porter, cameras and whisky. Immortal gods! what punishment has mankind ever devised adequate to fittingly reward the tourist Goths and Vandals who would strew their base sardine tins, their abominable sandwich wrappers, and infernal rum bottles over this splendid picture in the art gallery of Nature! Within a radius of two miles of the Whelanian Pools is probably a larger number of lovely scenes than in the same distance in any other part of Australia. Mr. Bailey went down with me to see the Morehead Cataracts, and after a brief admiration of the scene he proceeded to describe the surrounding vegetation in names that I dare not mention here, having already been called on to pay several bills for surgical operations on citizens who threw their jaws out of gear over my last article. One of the plants was the Pogonatherum saccharoideum, an Indian grass, found there for the first time in Australia. On the third day at the Pools, Whelan and myself went up the main spur running to the South Peak, and cut a track for 2,600 feet, to enable the blackboys to carry their packs during the ascent. At 2,300 feet we were fortunate to find the fruit which Mr. Bailey has named Garcinia Mestoni, or "Meston's Mangosteen," the first of the Garcinia family found in Australia. The trees we saw-at this point only and nowhere else-were about 15 feet or 20 feet high, handsome little trees, with the leaves drooping in clusters, a fruit hanging pendent in the centre of each cluster. On my first trip to the mountain this fruit was found in a ripe state and large as a full-sized orange. In all stages, ripe or green, it is a bright olive green, and can be eaten in any condition. When ripe it has a very pleasant acid taste, with a delightful flavour. When only half grown, as we found it this time, it was eaten by the whole party, and had a most refreshing effect on a hot and thirsty day. It is certainly a remarkable fruit, and Mr. Soutter, of the Acclimatisation Gardens, will doubtless do his best with the seeds brought down by me on a previous occasion. Baron Von Mueller thinks the discovery of this one fruit alone would have repaid Mr. Bailey for all his journey, but Mr. Bailey has added to botanical science, besides the Garcinia, a greater number of new species than were collected during the whole of the Owen Stanley expedition in New Guinea, the latter, too, ranging 
over both tropical and Alpine flora. And Mr. Bailey has not yet done classifying his specimens, nor touched at all upon his cryptogamic plants. And only a fraction of the flora of Bellenden-Ker was fruiting or flowering during our visit, so the rest had therefore to be left uncollected! On our way up the spur we shot some pheasant-tailed pigeons, and heard the solitary harsh note of the rifle bird in all directions. Here, too, was Spalding's Orthonyx (called "chowchilla" by the blacks), or the " spine-tailed scrub bird," a very noisy bird, with a rich, full note, and great powers of imitation. He is conspicuous by the size of his feet and strength and thickness of his thighs. The scrub hen, one of the moundbuilders, was also plentiful, but the scrub turkey is rare, though this bird travels to even higher altitudes than the scrub hen, the nests being discovered over 4,000 feet, much smaller than the nests on the level country, on account of the difficulty of collecting the dead leaves.

On Thursday, 20th June, Bailey, Whelan, Harold, and myself started to ascend the mountain, leaving Broadbent and all the blackboys, except one, to follow next day loaded with provisions. The camp at the Pools was the second base of supplies.

We travelled slowly up, partly for Bailey's sake, and to allow him to observe the flora as he went along. From 2,600 feot we had to resume our track cutting, no specially pleasant work for Whelan and myself when carrying $40 \mathrm{lb}$. loads, and required to find the proper course to take. About 4 o' clock we arrived at 4,000 feet, and camped under a splendid palm tree about 20 feet high, shading a circle 30 feet in diameter. This palm Mr. Bailey may find to be a new species.

About 200 yards from this palm, down a descent of 100 feet, is a stream of clear cold water forever running. Temperature of water, 58 degrees; atmosphere at night, 56 degrees ; day shade, 62 degrees; We were now in the habitat of the tree-climbing kangaroo, called " mappee" by the blacks. The south peak of Wooroonooran was still six miles away, 1,000 feet above us, through dense scrub. Mr. Bailey had made the ascent of 3,000 feet from the Pools without much fatigue, and in ten minutes after arrival was scattering ten-syllable words broadcast among the surrounding vegetation. During the night some audacious animals came and took an open tin of mutton, a pair of socks, and some biscuits from within a yard of our heads. These omnivorous marauders were caught in traps on a future occasion, and proved to be two huge native cats of a species found only north of Cardwell.

Next day, the 21st, we were out collecting part of the day, and Whelan and myself cut the track on to the second water two miles ahead, being able to follow some faint marks left by him, Barnard, and $I$ on a former flying trip, and so possibly saved a little time at a point where spurs radiated to all points, and only one went in the right direction. One main spur diverges here and runs away to Bartle Frere (Chooreechillum) and junctions with a spur from that mountain, the saddle forming the divide between the waters of Tringilburra and Babinda Creeks, one running to the Mulgrave, the other to the Russell. In the afternoon Broadbent arrived with five boys loaded with provisions. One of the troopers remained with Beman at the lower camp, and one in charge of the camp at the Pools.

I omitted to mention in my last that Swallow and Derham very kindly and gratuitously sent me a Pentecost Island boy named 
Multarri, as an assistant on the expedition. We had then four boys of our own, the other three-Jimmy, Charley, and Butcher-being natives of Tanna. Butcher was sick for a week after the first day's journey, but recovered and worked well ever after. Jimmy was an active, powerful boy, a keen sportsman, and capable of great endurance. Altogether they were as good a lot of boys as we could have found in the colony, and worked cheerfully from start to finish, frequently under very disheartening conditions. On the following morning we all started for the summit and arrived there at 2 o'clock, Whelan and myself having cut through four miles of vegetation that must be seen to be understood. This was the most miserable night of the whole journey. We camped where Whelan, Barnard, and I stayed all night on the first ascent. We required all the afternoon to clear enough space to erect a camp, so thick and hard were the trees and shrubs around us. A light drizzling rain was falling, the thermometer stood at 52 degrees, with a strong wind cold enough to freeze a Kamschatkan. At night the rain flowed under the camp, so we were all lying in more or less water, and nobody slept more than a couple of hours before the longed-for daylight arrived. Next day all the mountain was enveloped by clouds, a light rain falling, the trees dripping like a mild showerbath, and no view in any direction. Even the giant form of Chooreechillum was invisible across the intervening abyss. Whelan and I started to cut a track towards the centre peak, distant about two miles. What a wet, cold, miserable piece of work that was, the trees adding their heavy drops to the wretched drizzle from the clouds! After half-a-mile was traversed we returined to the camp, which was now properly constructed for a few days' residence. Next day was also cold and wet, and Whelan started down the mountain, taking all the boys, except Multarri, to send up a fresh lot of provisions, as we contemplated staying on the summit for eight or ten days. Bailey, Broadbent, and Harold were out collecting, and I went away alone to continue the track to the centre peak through vegetation simply indescribable, and reached the crest of a low spur, covered like all the rest of the South Peak by the magnificent dome-topped tree described in a previous article. Mr. Bailey tells me this tree belongs to the myrtle family, and is entirely new to botanical science. In my official report is the following passage in reference to this tree :-

"The whole south end of Bellenden-Ker from the centre peak broadens out to about three-quarters of a mile in width by two miles across from the peak to the outer edge opposite Bartle Frere. This area consists of low short spurs running in all directions, covered by thick vegetation and loose granite rocks, intersected by watercourses with beds of clean granite gravel. The trees are nearly all short and guarled, and all, without exception, hard as bone. Many of them when cut prove to be highly and pleasantly odoriferous. Conspicuous among the vegetation is a dome-topped tree with foliage so thick that not a ray of sunlight penetrates, and the outer top is so perfectly level that two men viewing each other from the summit of two of these trees appear exactly as if they had protruded their heads from the domes of two green pavilions, only the heads visible. One beholds a strange and beautiful sight by ascending a tree and looking over the tops of the others, which appear like a lovely leading colour in the tesseraic floor of various shades of green covering the mountain away towards and over the centre peak." 
The worst tree to cut through is a Dracophyllum, bearing a magnificent flower about 10 inches in length, like a small core of a maize cob covered by lovely tiny pink and white and blue flowers, and terminating in gorgeously-coloured pointed leaves. As the work of the 25th requires some special description, I will conclude this chapter with a little episode at the Pools the first night we camped there. The pavilion camp was pitched on the centre of the rocks out in the open, Broadbent's tent by itself about twelve yards away. Broadbent was reading to a late hour, and went to sleep leaving his candle burning. On the pole of his tent over the door he hung a towel and about $10 \mathrm{lb}$. of corned beef. Two men with no clothes on might have been seen at midnight standing out on the rocks, in the dark shadows, hatching a deep unscrupulous conspiracy. One of these ruffians, bearing a strange resemblance to the leader of the expedition, was seen to creep stealthily and noiselessly into Broadbent's tent, gently snuff out the candle, remove the corned beef and towel, and plunge into the surrounding gloom. At daylight Broadbent roused us up to announce that a barefaced impudent robbery had been committed by a myall during the night, and that we were extremely fortunate in not all waking up, like the two Irishmen, to "find ourselves defunct!" Whelan and I at once started off on the warpath up the creek to discover the tracks of the marauder or perish. I returned in about a quarter of an hour to say that we had found traces of the thief, and Whelan was away in hot pursuit. In about half-an-hour a shot was heard away up a lonely ravine, and shortly afterwards Whelan returned carrying the corned beef covered with gravel, and the towel looking as if it had been dragged down Queen-street on a wet day behind a tram-car. Broadbent smiled sweetly over the swift and terrible retribution that had overtaken his enemy. He seized his towel with a look of grim satisfaction and gazed sadly at the mangled fragment of dilapidated sirloin. Thus all ended according to the strictest principles of eternal justice, but there are still living on this planet two men who ought to consider it a solemn duty to pray earnestly for Broadbent's forgiveness before they die.

\section{No. III.}

On the 25th of June I started to finish the journey to the centre peak. Broadbent accompanied me, leaving Bailey and Harold collecting on the south end of the mountain. The day was cold, thermometer rising only to 50 degrees at midday, and the usual merciless wind blowing from the Herberton tablelands. Vegetation all wet, and light showers falling at intervals. At noon we stood on the centre peak at a height of 5,240 feet, the first men who ever put a foot on the highest point of Bellenden-Ker. All the way to the extreme verge we passed through dense brushwood and short tree ferns. The peak narrowed to about 30 feet wide, covered chiefly by the Dracophyllum and the dome-topped myrtle. Among the smaller shrubs was one bearing a small white flower, with a delightful perfume which filled all the atmosphere around. A large myrtle had partly fallen on the outer point, and on the trunk of this we stood free of all surrounding vegetation, with a clear view to all quarters of the earth. And what a 
scene! We were about 300 feet above the clouds; overhead the blue sky unsullied by a single speck. It was exactly such a scene that Sir William Macgregor looked down on from the summit of Mount Knutsford at 11,000 feet, only he was 3,000 feet above the clouds instead of 300 feet. But his additional height was no advantage whatever. We could have seen no more from the crest of Everest or Chimborazo. Once above the clouds you gain nothing by further ascension, so far as scenery is concerned. The view from the top of Bellenden-Ker, either in clouds or sunshine, is quite equal to that seen from the loftiest heights of the Owen Stanley Range, judging by Sir William's description, and even liberally filling up the far too meagre outline he gives to us in his report. Doubtless he would have supplied a much more graphic description had he been quite sure it was compatible with the usual solemn and soulless language of official documents. He compared the clouds below him to "an Arctic world of frozen snow," and this applies accurately to the scene which Broadbent and myself witnessed from the centre peak.

How unspeakably poor and mean in comparison with that sublime reality are all the most gorgeous fancies of even the finest imaginations! You dare not speak nor cherish an ignoble thought, standing there in the presence of that transcendent picture suddenly unfolded before you by the hand of the Almighty Artist. One vast waste ocean of magnificent clouds-purple and blue and white and red and golden-stretcbing away to the edge of the remote horizon, all rippled into fantastic, motionless waves; here and there a dark mass like some solitary island in the eternal sea, and to the right the dark lone crest of Chooreechillum rising a hundred feet from the surrounding cumuli into the overarching blue. Eastward the cloud ocean stretched away in long low waves with rippled crests, until it ended in a border of gorgeous purple, above that a long straight amber-edged billow of snowy white, and over and above all, "through the abyss of the immense concave, radiant with million constellations," the calm clear blue immeasurable azure, the pathway to Eternity.

- Northward, beneath the sunlight, clouds rose in gigantic shadowy shapes like hills torn from their foundations and hurled in wild confusion from the skies in some empyrean combat of the gods and demons.

\footnotetext{
Mountains toppling evermore

Into seas without a shore;

Seas that restlessly aspire,

Surging into skies of fire.
}

And slowly two of these enormous vapours rolled apart, disclosing far away a long avenue with descending streams of soft gray light, like rivers from the Sulphur Throne of Pluto, spanned by myriad rainbows, and falling silently into bottomless ravines of purple snow. And from the many-coloured abyss, driven upwards by sub-vaporous winds, there drifted multitudes of small white clouds, rising from the red depths like birds from the funeral pyre of some celestial Memnon, around whose last couch all the mourning Cherubim and Seraphim had spread the dazzling glories of God's everlasting Universe.

Three hundred feet below us, down the green face of the mountain, across the slopes strewed with flowers and living leaves, the waves of that cloud ocean rippled noiseless on the echoless shore. And around and over all was the silence of the grave, save the soft sad Eolian 
melody played by the wailing winds on the harp of beautiful trees, that bowed their green heads gracefully as if in speechless adoration of a scene for which even all Nature's reverence never ceased. Out in that silent sea it seemed as if one could float away, like the dead Balder, the Sun God of Norse mythology, in some magic fireship, drifting away into the deep of time, to silence and oblivion, the sole refuge for all those sick and weary of the crime and misery of the earth. Here, indeed, on this lonely peak was a suitable habitation for noble souls, those who commune with the wrecked heart like a musician with his broken harp. Souls in whom no wind from Heaven shall again waken the Lydian melody of the vanished years. The mournful memories of the loved and lost, side by side with dead hopes and baffled aspirations, drifting slowly, like spectral icebergs, across the frozen ocean of the heart, through dark shadows deepening in the gloom of the Arctic winter towards the eternal night.

On returning to the centre peak next day with Harold the scene was changed. Not a cloud was visible in the circle of the horizon. The atmosphere was phenomenally clear. We stood in the centre of a circle 300 miles in diameter, Mount Elliott clearly visible 150 miles to the south. The ocean lay silent below us; the surface rippled like a vast sheet of blue steel, the distance too great to see the motion of the waves, and curving up into the sky-line until it was impossible to tell where ocean ended and sky began. We saw the whole watershed of the eastern and western rivers from Cardwell to the Bloomfield. The Johnstone River, with its plantation clearings and sugar-mills, was seen as plainly as if we were only ten miles distant. We commanded a complete view of eight coast rivers - the Barron, Mulgrave, Russell, Johnstone, Moresby, Liverpool, Tully, and Murray-and the whole of the country they drain. The sound of the blasting on the Cairns Railway was astonishingly distinct, though between sixty and seventy miles away. To the west the horizon was bounded by mountains, vague and shadowy in the remoteness of distance. All the intervening space in that enormous amphitheatre was filled by vast plateaus, hills and peaks, ravines and valleys, all covered by dense, dark, tropical jungle.

Chooreechillum, broad based on his rock foundations, stood facing us across the abyss. Like Jira, answering to the joyous Alps, he called to Wooroonooran from the Silences, the voice of deep answering unto deep. These two giants of the tropics have stood there since the day that the earthquake Iucina delivered them from the womb of Chaos, far back in dark Creation's dawn. They stood there when Solomon was building his Temple, when Menes was building Memphis, when the Egyptians were erecting the Pyramids, when the earth witnessed the Deucalion Deluge; while empires and nations were rising and falling and rustling off, like burning paper, into silence and eternity. They looked down on the Pacific on the day that Captain Cook's white-winged ships entered Trinity Bay, and the myalls gazed with awe and wonder from the rocky cliffs of Cape Grafton at the mysterious strangers appearing thus suddenly from the Unknown. They have seen the Australian nation rising into robust youth, and they will be standing there solemn and inexorable and heedless as Destiny, when in coming ages, far or near, all the record of our existence may be-

A cry of Nations o'er our sunken halls,

A loud lament along the sweeping sea. 
Some day they may have to gaze down on the calm Pacific when Australia's sons are engaged on its bosom in a death struggle for freedom, when "blood stains the snowy foam of the tumultuous deep," and the battle thunder rolls higher than the roar of the resounding sea.

On the night of the 25th the thermometer fell to 30 degrees, or 2 degrees of frost, 14 degrees lower than Sir William Macgregor found the coldest air on the highest peaks of the Owen Stanley Range, though he saw large icicles and was above the snow line. On the 26th the temperature only rose to 40 degrees at midday. We were unable to sleep much at night, finding it impossible to keep sufficiently warm. The 26th was the first fine day on the summit, and Harold, Multarri, and myself went over the centre peak and about a mile beyond, along the crest of the mountain.

Received a note from Whelan to say he would not be able to rejoin us for a couple of weeks, on ascount of the murders by the blacks on the Upper Russell.

From the south peak of Wooroonooran we overlooked the scene of these murders. On the 27th, we all left the summit for the Palm Camp at 4,000 feet.

We arrived there at noon, and I left Bailey and Broadbent with two blackboys and a week's provisions to stay collecting for four or five days. Continuing on down the mountain with Harold and two blackboys, we arrived at the Pools and found two of the troopers in charge of the tent. One night Susie, a Thursday Island boy, had a visit from a myall. Susie was seated inside the tent just at dusk, and had the candle lighted. Suddenly a black hand was pushed under the canvas, and was seizing a tin of preserved beef, when Susie called out, "What name that fellow ?" Then the myall actually had the audacity to come round and sit down on a stone at the door of the tent. Susie had my Snider rifle in his hand, and when he raised it-just as a mere formality-the myall started for distant climes. Susie says the rifle went off sumehow or other, and that the myall did the first hundred yards in nine seconds. On another night Terrick was in charge of the same camp, when an old man myall, of the true cannibal breed, strolled softly up about 5 o'clock in the evening. T'errick's yarn was that ho told the ancient warrior to come back when " master" was at home, and that the visitor thereupon politely departed. There is still a grave doubt hanging over the nature of the reception accorded to both visitors. At the Pools, on the 27 th, the water was 56 degrees, and the air 58 degrees at night. The water was the same night and day. On the 28th we loaded up to remove the Pools camp to the base of supplies at the foot of Barnard's Spur. On arrival there I found Beman alone, camped under a pile of dead grass at the foot of a tree, and the wholo of our things stowed away in the scrub. He had neither tent nor firearms. Had the blacks come in he would have been a gone coon, and so would all our goods. The mistake arose partly through one of the boys, and partly through Beman's own weakness in allowing a trooper, in error, to take away the rifle and the tent. The arrangement I made provided for a blackboy always in company with Beman, as neither for his sake nor our own would $I$ have left a new chum alone in such a dangerous locality. Immediately on arrival I sent the troopers home to the Police Camp on the Mulgrave to start out with Whelan next morning.

Whelan regarded his sojourn with us as highly advantageous to himself and his troopers, as it gave him and them valuable information 
concerning country into which his official duties might require him to travel at any time. He had the roughest country in Australia to hunt over when after the blacks-high, steep, rocky mountains, with dense scrub full of leeches, and tropic rains falling about six months in the year. I learn that he has since been promoted-a just and graceful recognition by the Commissioner of his services as an energetic and conscientious police officer. On the 29th the blackboys went back to bring down the balance of the things at the Pools, Harold stayed in charge of the camp, and I went away up a mountain to the eastward, on to the crest of the first spur at a height of 2,000 feet. This mountain is known to the expedition as Mount Harold. It is composed of slate and huge quartz reefs which "blow" all over the surface. The spurs are lightly timbered with small patches of scrub in the ravines. Had a dangerous fall through wearing a pair of ordinary boots which slipped on the edge of a precipice, but I fortunately brought up on a narrow ledge overhanging a sheer descent of 300 feet, and managed to edge along to the loose rocks on one side and regained a secure footing It was one of the very narrow escapes of my lifetime. The gun had fallen into a crevice, and I managed to recover it There were blacks' camping-grounds all over the range. On this mountain are dark red wallabies with long tufted tails, the wildest animals ever I saw in Queensland. I ascended that spur three times with gun and rifle, thus covering 6,000 feet of climbing, to obtain a specimen, and failed on every occasion. Once I took up Broadbent, Harold, and Jimmy, and though we saw them every time not one of us succeeded in obtaining a shot. My opinion is they are an unknown species.

On Sunday, the 30th, Beman and Jimmy returned again to the Pools, and brought down the last of the camp. On 1st July, Beman and Jimmy started off to assist to bring down the party from the Palm Camp. Charley remained in charge, and Harold and I went away collecting up the dark ravines under Mount Sophia. The formation here is chiefly slate and quartz. There are traces of tin, and it is also a very likely place for gold, though we saw none. There is a considerable quantity of heavy timber with running creeks in all the ravines, where the rocks and loose stones are covered by luxuriant and lovely mosses. The rank vegetation everywhere indicates perpetual heat and moisture. The creeks and ravines here display some specially beautiful scenery, and have the merit of being very easily accessible by tourists.

It seemed a place where angels might repair,

And tune their harps beneath the tranquil shades,

To morning songs, or moonlight serenades.

On the 2nd my son and I again ascended Mount Harold to 2,000 feet, and procured several botanical specimens, but no wallabies.

On the 3rd, Bailey, Broadbent, Beman, and the three boys arrived, having slept the previous night in the blacks' camp on the top of Barnard's Spur. This was the only occasion on which Mr. Bailey looked ill during the trip, but he soon recovered. He had really done the journey wonderfully well, and was uniformly cheerful at all times, with never-varying enthusiasm for his work. As for Broadbent, he went out shooting all day and sat up half the night skinning his birds. 
No. IV.

After the return of Bailey and Broadbent from the mountain, we remained seven days collecting around the camp on Tringilburra Creek, beneath Mounts Torressa and Sophia. During this period we explored the whole surrounding country. One day Bailey and Broadbent, when out together, found the skeleton of a myall among some rocks, and brought the skull in for the museum. Here also we got a carpet snake, about 8 feet long, containing a small wallaby. How so large a beast was swallowed by so small a reptile is a mystery to everybody but the snake. Carpet snakes are numerous all through that country, some of them being found up to 16 feet. We saw very few snakes; but the cold weather would account for their absence. There were few ticks and few leeches in the scrubs, but in the wet weather in the hot months leeches are in tens of thousands in the scrubs of the upper Barron and sea-coast ranges. We were not troubled by mosquitoes in any of the country we passed over, nor are they numerous anywhere on that coast at any time of the year, if we except the mangrove swamps and the tea-tree flats on the low wet lands of the coast.

On the night of the 4th the temperature fell to 42 degrees. During the day Mr. Bailey and I were out under Mount Toressa, and on crossing the main creek had a small accident, happily attended by no serious consequences. During our stay here the Government prospecting party arrived, having worked their way across from the Clohesy, along the head of Freshwater Creek, without any results. The work done was far too superficial and too hurried to be any reliable evidence of the minerals in the district passed over. Information collected on imperfect examination may be worse than useless by misleading others who would do the work much more effectively. 'The weather was beautifully fine, with cloudless moonlight nights. Temperature at night, 54 degrees ; midday, 80 degrees.

On the 7th Whelan came over from the Mulgrave. On the 8th he and I started with three blackboys to go round the whole BellendenKer Range from south to north. We sent the boys on to meet us on the top of Barnard's Spur, and Whelan and I went up the main creek. A mile above the camp this creek is broken by a succession of magnificent falls. Ascent is difficult and dangerous. One must possess trained muscles and be sure of eye and foot and hand. A slight mistake on the face of a cliff or a slip on a narrow ledge would end in swift and certain destruction. The mountain spurs approach on each side and end suddenly in walls of perpendicular or overhanging rocks. One scene is alone worth all the journey, and, happily, that can be approached from Barnard's Spur by a route easily accessible even by ladies. Many a painter and landscape photographer will yet give that splendid picture to the world. Descending a forest spur to the edge of the creek you stand out on a projecting shelf of rock clear of all obstructions, and command a perfect view of three entirely different scenes. On the right hand, close beside you, is a fall descending 100 feet into a vast circular basin cut out of the solid rock. Immediately below that are two other falls, presenting only the curve of the foam-crested torrent rolling over the edge of the abyss. On the left is a deep clear pool 100 yards long between two vertical walls of rock. The upper end to this pool receives the whole 
stream descending from a precipice 100 feet in height. At the lower end of the pool the water flows over a narrow ledge down the fall right beneath where you are standing. Directly in front, not 50 yards away, a large stream descends from a ravine in the opposite mountain and falls clear down with terrific force about 200 feet into an oval-shaped rock pool, from whence it emerges under an arch spanned by a single block of granite, and joining the main creek both flow over the ledge together into the cataract below. All these three falls are within 100 yards of the spot you are standing on. These are the "Francesca Falls." All round are glorious ferns and flowering orchids, chief of which is Bailey's orchid (Bulbophyllum Baileyi), which appears here to attain its nnaximum of perfection. From this point right up the creek to the Morehead Cataracts there is a succession of splendid falls, cascades, and deep still pools, forming one continuous picture of sublimity and weird and awful graudeur, indescribable and unimaginable. Arriving near the Morehead Cataracts, we turned to the eastward up a steep spur, and ascending 800 feet arrived where the blackboys were at the blacks' camp at 1,700 feet. Rain came on with the darkness, and fell heavily all night. As the roof of our camp leaked we had to postpone sleep to a future occasion. In the morning the two creeks at the Pools were uncrossable, so we had to go back down Barnard's Spur, and on arrival at the foot found the main creek flooded and roaring through the granite rocks like thunder. Each one selected his own place to swim across-rather a dangerous work for all of us-and Whelan and I marched into camp without our clothes, somewhat to the astonishment of Mr. Bailey, who was attentively examining a plant with a name as long as that of a Madagascar prince. On the 11th we all left for the Mulgrave plains, where we remained until the 18th, collecting down both sides of the creek and along the Mulgrave. Game was abundant here, and we could have shot far more than the camp required.

One day, the 12th, we collectively brought in twelve pigeons, five scrub hens, two turkeys, six cockatoos, two rifle birds, one dragoon bird, and sundry others. On the 13th Whelan again left for the Upper Russell diggings, being advised of fresh murders by the blacks.

On the 18th, leaving Beman in charge of the main camp, and discharging Butcher, we started for Harvey's Creek, on the Russell, a distance of fourteen miles, Bailey on horseback, and Broodbent, Harold, the two blackboys, and myself on foot. At Harvey's Creek we were again joined by Whelan. Next day one of the troopers, and Jimmy, the Tanna boy, started up the Russell, a distance of thirty miles, to meet an aboriginal named "Yabba," who was to join us at Choonbine bora'ground, for the ascent of Bartle Frere (Chooreechillum). Next day Whelan and I started on the same route, and camped that night at "Teechappa," a bora ground twelve miles from Choonbine. The road was along the valley of the Russell, all the way through dense scrub, perhaps the thickest in Queensland. From Teechappa to Choonbine, we were crossing the terminal spurs of Bartle Frere. In the twelve miles there are actually twenty-five running streams of water, not surpassed in Australia for purity and drinking qualities. At Choonbine we found Jack and Jimmy and Yabba camped under a tree. This Yabba was a strong, active, rather pleasant-looking fellow, with somewhat light limbs slightly curved 
below the knee. He had been out prospecting for several months with a miner named Chandler, who very kindly sent him to Choonbine to place his services at our disposal.

At 3 o'clock p.m. on Sunday, the 21st of July, we started from Choonbine to ascend Chooreechillum. The route was through a thick scrub all the way to the summit. After ascending 2,000 feet we camped on the crest of a narrow spur about twelve yards wide, a running stream about 150 feet below us to the westward. We made a bed of tree-ferns, and having no blankets the duties of the chambermaid were of a light and irresponsible character. During the night Yabba was very restless, and twice he rose and walked round the camp. Somehow I mistrusted that smiling plausible savage. Twice he stood and gazed for some time at the two sleeping blackboys, and now and then cast uneasy glaces at Whelan and myself who were about five yards away. Then he sat down and meditated by the fire. Who shall say what midnight thoughts were passing through the brain of that wild dark son of the mountains? Perhaps he was calculating the chances of the future in case he brained us all with the tomahawk. But the scrub knife and the tomahawk were under my head, and I myself was very much awake, and any hostile movement by the gentle Yabba would have ended prematurely and abruptly, and the subsequent proceedings would not have interested him to any great extent. My suspicions will be shown later on to have been founded on a solid basis.

On the 22nd we started up the mountain along a steep spur covered by tall heavy timber, and enormous masses of granite rocks. At 3;000 feet we passed the frame of a camp erected by Christie Palmerston, when he was up there with a lot of blacks and Mr. Jack, the geologist, in February, 1888. It stands on the edge of a precipice formed by a landslip. At 4,000 feet we halted half-an-hour beside a small rivulet of pure cold water, probably the head of the stream that descends about 2,000 feet almost perpendicularly on the eastern face of Bartle Frere, forming the Hume Black Falls, which may safely be classed among the highest in the world. These falls can be seen from steamers passing along the coast off Point Cooper, between the Johnstone River and Franklyn Islands. At 4,500 feet we emerged from the scrub into an open slope covered by stunted bushes and small shrubs, and creeping plants growing over loose boulders. Above us on the crest of the slope towered gigantic granite rocks, pyramids, spires, pillars, domes, and obelisks, some of them 50 feet or 60 feet in height. On passing out into the open, Yabba paused and cheerfully remarked, "Good day, Chooreechillum." Never before had he stood on that summit, though the foot of the mountain was his birthplace. About 3 o'clock on the 22nd we stood on the highest peak of Chooreechillum, the aneroid showing a height of 5,070 feet, or nearly 200 feet lower than the centre peak of Wooroonooran. All round, and below and above us, was a wild sea of dark clouds, involving and involved, driven downwards and upwards in the pitiless combat of contending winds. The view was bounded by a circle of 100 yards. On the north side of the peak we found the trees marked by Palmerston on 26th October, 1886, and by Geologist Jack on the 9th of February, 1888. Conspicuous on Bartle Frere was the total absence of the dome-topped tree which covers the south end of Belienden-Ker, and has been discovered to be new to science, and named by Mr. Bailey 
Leptospermum wooroonooran. Equally astonishing was the total absence of Dracophyllum Sayeri, the magnificently flowering tree seen everywhere on the summit of Wooroonooran. And yet these two mountains stand facing each other, their spurs actually connecting on the divide between Tringilburra and Babinda Creeks. In place of the absent trees were two strangers entitled to almost an equal position. They are both named by Mr. Bailey as new to science. One is the Orites fragrans, a tall shrub with dense spreading foliage, bearing a delightfully fragrant and very beautiful purple flower. The other is Melicope chooreechillum, a small handsome tree with lovely white flowers. Here also we got the Mronotoca lineata, found now, according to Mr. Bailey, for the first time out of Tasmania. It is a small tree bearing a tiny five-celled fruit of a rich red colour. There was no sign anywhere on the mountain of Garcinia Mestoni. The regetation of Chooreechillum is really quite different to that of Wooroonooran. This is an extraordinary fact. We camped all night on the summit beside a huge mass of granite with a small cave in the centre. Rain had fallen all the afternoon, and continued through the night. In the morning there were light showers still falling. We explored the summit all round-a wild, savage, inhospitable region piled with rugged masses of granite rocks upheaved in dark confusion, as if thrown there by an earthquake. In places enormous fragments 20 fect or 30 feet in diameter were piled one above the other; gloomy caves beneath, and shadowy crevices between. Around and over all grew beautiful orchids and ferns, and strange flowering plants in apparently endless variety. After two hours' collecting we returned to the bare face of the summit on the eastern side, and sat down on a flat rock to have a calm view of the surroundings. Human voice or pen can give but a faint idea indeed of the abysmal gloom of that tremendous solitude. We were surrounded by a world of clouds, even the rocks within a hundred yards above and below us but faintly seen like tombstones in the morning mists. Never before did I experience the same sensations. Rising over all was man's sense of his own unspeakable insignificance. It seemed as if I had been suddenly ushered, like Ulysses, into the realms of Death,

Where side by side along the dreary coast,

Advanced Achilles' and Patroclus' ghost.

In fancy the spectral clouds assumed the shape of some Tiresias rising from the awful Shades. The lighter mists were driven by the winds swiftly along dismal avenues of enormous vapours, moving slowly onward, black as night and silent as the voiceless grave. Imagination pictured the solemn phantoms of departed Ages stalking gloomily along through long colonnades of majestic clouds. The pale kingdoms of Dis marshalled their mournful ghosts. Once only, and for a few brief seconds, did we behold the dark form of Wooroonooran, through a wind-divided chasm of rolling clouds, apparently far above us, a vast black shape revealing itself, and disappearing again in the realms of gloom. And once only did the clouds lift like a mighty curtain from the mountains to the north, displaying gigantic shadows resting in the umbrage of the peaks, and myriad columns of snow-white vapours shooting upwards from the ravines below, as if we stood over the abode of Lucifer, and in the nether depths

All Hell unloosed

Its mounded oceans of tempestuous fire. 
And then the sunlight came with all the varied glories of the dawn, and clouds became "red, yellow, or ethereally pale," and radiant rainbows spanned with their curving splendours the many-hued abyss; and for a few short moments we stood the centre of a hundred sunsets, lost in the magnificence of all the splendid shapes and colours of the wondrous God-created dome which overarches this mysterious earth. Those who hereafter ascend these two mountains will say with me that no human language can possibly exaggerate, or give more than a shadow of an idea of the scenes visible there in rain and sunshine, storm and calm.

We left the summit about 9 o'clock, and descended rapidly to Palmerston's camp at 3,000 feet. Both ascending and descending, above the 2,000 feet level, we saw tracks of the mappee, or treeclimbing kangaroo, but had no time to search for the animal. $\mathrm{He}$ goes right on to the summit. Frequently we heard the call of Meston's bower bird, and saw bowers of all sizes up to 7 feet in height. There were very few birds on the mountain, the silence was oppressive, and heightened by the sombre mosses which covered the rocks and draped the trunks and branches of the trees. At 2,700 feet we left the course of our ascent, and turned down a very steep spur towards the southeast, Yabba declaring this to be a short cut to Teechappa. Anyone who ever comes down that spur will remember it for a long time. We arrived at Teechappa with the last expiring daylight, and camped there in a Chinese store, leaving next morning for Harvey's Creek, making the whole journey of eighteen miles in torrents of rain. Before departing from Teechappa I presented Yabba with flour, sugar, tobacco, matches, and two red handkerchiefs as a gift from the Government of this great colony, and a reward for his services. He went away too happy to speak, never before having possessed such an accumulation of wealth. He promised to collect a lot of land shells (Koorajoon) for me, and bring them into Teechappa. Alas! A few days later we learned that this genial savage, whom I had watched at the camp fire, was one of the worst of the Russell River murderers, and killed two of the unfortunate diggers with his own hands. Yabba is at present supposed to be collecting seashells on the golden shore.

\section{No. V.}

Heary rain fell all through the night of the 24th, the date of our return to Harvey's Creek, and continued over next day. All remained in camp on the 25th, except myself and Jimmy, who pulled two miles up the Russell, landed on the east side, and ascended the coast range to a height of 1,200 feet along a steep granite creek, forming a succession of beautiful cascades with alternate deep clear pools, cut clean from the solid rock. Gigantic and magnificent ferns, with leaves 15 feet to 20 feet in length, grow all along the basin of this lovely stream. Here I found a new plant, which Mr. Bailey has named Chavica Mestoni, or Queensland Long Pepper, a large climber adhering to the trees by adventitious roots. This plant is allied to the long pepper of commerce. Seven years ago on that same creek, at a height of about 800 feet, accompanied by John Nairne, we found a ripe fruit resembling a large elongated strawberry, possessing a delightful flavour and delicious taste unsurpassed by any fruit known to man. Both of us 
have since searched for it in vain, but I intend making one more final effort in the same locality, during the month it was first discovered. That fruit if cultivated would create a sensation among our gardeners. Next time I shall enlist the assistance of the native blacks.

On the return journey I made a third effort to obtain a shot at a huge crocodile that had his lair in a small patch of blady grass at the mouth of a mangrove creek, about a mile above Hickey's landing. On a previous occasion Whelan and myself had approached this lair from the land side, through dense mangrove and a vile swamp with grass 6 feet high. Each time the crocodile was absent. He had been seen repeatedly by settlers going up and down the river, and was described as an immense beast about 18 feet long. Jimmy stood and gazed in speechless awe at the camping ground of this tremendous animal, and the fresh marks of the enormous feet in the soft mud of the banks.

From this point, on which he had evidently been camped for months, he commanded a clear view up and down the river. On the appearance of any danger, he quietly glided into the water, and stayed there until it was over. Crocodiles are numerous in the Russell and Mulgrave, from the salt water far up to the deep fresh pools among the ranges. I have seen them in the Mulgrave above the Pyramid Plantation, and along the Russell for about forty miles. Bathing in the deep water of either of these rivers is a dangerous pastime. Dogs living in the vicinity may be said to carry their lives on their tails. The night of the 25th is remembered by a general discussion on the big trees of Australia and California. Each was under the impression that he had been specially favoured by a sight of the tallest tree in the world, until Broadbent informed us that in the Cardwell Range he saw a tree which had fallen across three creeks, and after that we all quietly and meekly retired to bed.

On the 26th of July we returned to the camp on the edge of the Mulgrave Plain, where Beman was left in charge. Just about sunset Harold went down in the scrub on the edge of the creek about 150 yards from the camp to shoot a scrub hen. We heard him fire, and then shout loudly and excitedly for assistance. He had shot a magnificent cassowary. He heard a splash in the creek, and thinking it was caused by one of the blackboys returning, he walked towards the edge of the bank, and, meeting the cassowary face to face, shot him dead at ten yards, with a charge of No. 4 shot from a 20-bore Adams. The youngster was mightily proud of that performance. This cassowary weighed $186 \mathrm{lb}$., the liver $4 \mathrm{lb}$., and the heart bigger than a sheep's. He is now set up at the Brisbane Museum, and may be safely regarded as the finest stuffed specimen in Australia. On the 27th Beman left for Sydney, deeply thankful to all the nine gods that his first colonial experience had left him alive and well. He was a very quiet, civil, and obliging young fellow. On the 28th three cassowaries were shot by Jimmy, making five fine specimens of this noble bird, Casuarius australis, obtained during our stay on Tringilburra Creek. On the 29th we shifted camp over to the police paddock on the Mulgrave, where Messrs. Bailey and Broadbent stayed collecting for ten days. On the 2nd of August I crossed the river to the foot of the Walsh Pyramid (Charroogin) accompanied by Jimmy, whom I sent away around the base of the mountain in search of red wallabies. The weather was cloudy and showery. Deciding to ascend the mountain I took off all 
my clothes, and placed them under a flat rock. Clad only in a pair of sandshoes, and carrying a light rifle and a score of cartridges, I started the ascent, on my third visit to the summit. This pyramid rises abruptly from the Mulgrave Plain to a height of 3,050 feet. There is no scrub on any part, light open forest clothing it all round from base to summit. This mountain could easily be ascended by ladies, being the most easily accessible of all the mountains in the Cairns district. Of course, a steep ascent of 3,050 feet, especially on a hot day, represents something more than amusement to people not accus. tomed to the mountains. The top commands a truly magnificent view in all directions. I arrived there about noon. The mountain terminates in a cone-shaped peak covered by masses of flat rocks. On three sides it falls off in very steep spurs, and on the western side you look orer the edge of a frightful precipice, nearly 2,000 feet in depth. In the crevice of a flat rock on the highest point grew a row of the beautiful terrestrial orchid Dendrobium speciosum, bearing bunches of splendid flowers. They were quite inodorous, but a bunch I took down for Mr. Bailey developed a very agreeable perfume after being hung up for two or three days. During the expedition we got twenty-four different orchids and 112 varieties of ferns. Nine of the ferns and two of the orchids are new to science. Descended from the pyramid with a bundle of botanical specimens and bouquets of orchid flowers, recovered my wardrobe, and arrived in camp about 5 o'clock. On the 5th of August I started for the ranges on the head of the Little Mulgrave, accompanied by Harold and three blackboys, Jimmy, Charlie, and Toby, the latter a native of the Mulgrave River.

Ascending the valley of Wright's Creek through thick scrub we camped that night on a small bare hill 650 feet high, just under the Main Range. Temperature at night, 56 degrees; day, shade, 78 degrees. On the 6th we started up the range on a forest spur covered by long grass. It gradually became steeper until the last 200 feet had to be ascended on hands and feet. When I reached the top and watched the boys and Harold coming up the slope, with precipices on each side, and knew that a single slip meant nearly certain destruction, it seemed to me that the risk was too great for the reward. And up that steep ascent I carried not only my own load of $20 \mathrm{lb}$., besides gun and cartridges, but half the swag of Toby, who had knocked up, being soft from long residence in town. We camped at 2,450 feet in an open space on the edge of very thick scrub. Night, 56 degrees ; shade, 74 degrees.

Next morning we started at sunrise, each one eating his breakfast as he walked along, to save time. All day we travelled along the narrow crest of the range through dense scrub, where I had to cut a track all the way for the loaded boys. With the exception of some assistance received from Whelan, I cut every foot of the tracks during the whole three months of the expedition. This work in unknown country cannot be done by a blackboy. The man in the lead has not only to cut the track, but determine the proper route to take, and exercise reliable judgment in selecting the easiest path. Only a bushman can realise the full meaning of that sentence. Conspicuous on this range was the vast quantity of splendid timber, many of the trees 6 feet and 7 feet in diameter - a species unknown to me; tall, straight trees, with rough, scaly bark, and no branches for 60 feet or 80 feet; woodihard, with a slightly golden tinge. 
We passed through clumps of magnificent palms, 20 feet to 30 feet in height, each tree shading a circle 20 feet to 30 feet in diameter, the ground beneath bare of all vegetation, and strewn with a soft carpet of dead leaves. About midday we found a wallaby skeleton, with bones complete. Concerning these osteological remains, Mr. de Vis remarks - "A padymelon, allied to Halmaturus thetedis, from which, however, it differs considerably, possibly an undescribed species." Heaven only knows how a wallaby ever found his way to that locality. He must have sighed for a lodge in some vast wilderness, some boundiess contiguity of shade, where myalls cease from troubling and wallabies are at rest. He was evidently a lost wallaby, driven there by dingoes, or wandered from the forest spurs on the sides of the ranges. In my official report is the following passage:- "At noon we were on the head of the Little Mulgrave and Freshwater Creek, on a mountain 3,000 feet high, commanding a complete view of a vast expanse of country. It may be well to mention here that when Christie Palmerston was across there about three years ago, looking for a railway track at the request of the Government, he reported the discovery of 30,000 acres of 'grand country' on the head of Freshwater Creek, and induced the Minister for Lands to reserve that area. It is my duty to report here that these 30,000 acres of 'grand country' exist nowhere outside of Palmerston's imagination. The heads of Freshwater Creek, the Clohesy, and Little Mulgrave rise in rough broken ranges and deep rocky gorges, and there is not 100 acres of level or available country on one of them."

The site of Palmerston's valuable 30,000 acres is occupied by useless mountains suitable only for goats and rock wallabies. He made the same error as the highly imaginative New Guinea explorer, who examined that country from the deck of a cutter, and located a bogus mountain 38,000 feet high on what is known now to be a swampcovered plain.

That night we camped at 3,100 feet, on a thickly timbered peak, lonely enough to satisfy the saddest mortal who ever longed to retire from this earth, and hide his

Abandoned hope and love that turns to hate,

And self-contempt, bitterer to drink than blood,

in beautiful, but unsympathetic, Nature's dark and remotest solitudes !

The ground being all wet we cut down the ferns and made couches, more expensive than any occupied by modern kings or queens. Bailey estimated the London value of the ferns cut down in the ascent of Wooroonooran at $£ 5,000$ ! In twenty minutes on that peak we destroyed plants that no money value would represent if growing in the botanical gardens of Europe or the conservatories of the millionaires of Britain. We carried no tent, only a strong calico fly sufficient to cover us all in wet weather. One blackboy slept at my back, one at my feet, and one between me and the fire; Harold lying across beside my head. Temperature at night, 58 degrees; midday shade, 72 degrees. During the day, while on the top of a mountain at 3,200 feet, I was fortunate enough to discover the îrst nest and egg of Prionodura (Meston's Bower Bird), the bird with the golden collar and golden crest. The female flew off the nest, which was built in the fork of a small tree, about 7 feet from the ground. It was a cup-shaped open 
nest made from fibrous roots, lined with more delicate material, and decorated on the outside with little tufts of green moss. The egg is described by Mr. De Vis as a "pale yellowish grey, profusely freckled and blotched with pale brown." 'The habits of this extraordinary bower bird will be described in a future chapter on the "Birds of Wooroonooran."

About 2 o'clock on the 8th we were on the top of the mountain overlooking Swallow and Derham's plantation, at a height of 3,640 feet. No view in any direction, the whole mountain being wrapped in dense white clouds. Our course that day had been along a range whose crest curved to different points. On arrival at the top the blackboys were completely puzzled, not having the faintest idea where they were, or the direction of north or south. Being asked where Cairns was situated, they all pointed towards Herberton. Harold's knowledge of locality enabled him to make a much better guess. Carried no compass on this or any other trip, except the one on which were fixed the exact relative positions of the Bellenden-Ker peaks and Bartle-Frere. Great was the astonishment of the boys when we started to descend one of the spurs to the eastward, and they were told the plantation was in that direction. They knew "master" too well at this time to credit him with a mistake. Sincere was their expression of joy when, after descending about a 1,000 feet, we heard the steam whistle of the mill faintly far below; for this had been a terribly severe trip, and the three of them were tired and leg-weary. The descending spur was steep and rough for the first 1,500 feet, then we left the dense scrub for beautiful glades of Casuarina torulosa (Forest Oak), with soft green grass growing beneath. This continued for 1,000 feet, and ended in a belt of scrub from which we emerged into dense rank dead blady grass that sent up flames to the tree tops. When about 300 yards in advance, $I$ heard voices in a gorge below, and hailed the strangers, not knowing if they were blacks or some of Swallow's kanakas out shooting. The replies indicated that the owners of the voices were in an advanced stage of excitement over being saluted by mysterious visitors descending on them from the dark unknown mountain overhead. Passing through a belt of thick scrub, I came suddenly on a small cutting, and two wild-eyed Chinamen brandishing lorg-handled shovels, ready to sell their lives as dearly as possible. They were up there cutting a race to give additional water supply to the mill. After leaving the plantation, where we were hospitably received, we walked on twelve miles the same night to our camp on the Mulgrave. We had travelled from sunrise to 10 o'clock at night.

\section{No. VI.}

The following is an account of the last and severest ascent of the Bellenden-Ker Range, and forms the final descriptive chapter of the expedition. That ascent was undertaken with a threefold object-to fix the exact position of all the peaks, to ascertain the nature of the vegetation, and to settle, beyond the possibility of dispute, the question of whether Sayer and Davidson or anybody else had ever been on any part of the northern summit-no one ever claiming to have stood on the centre or southern peaks. On Monday, the 12th of August, I 
started from the Mulgrave, with Harold and the blackboys, Charley, Jimmy, and Toby, in light marching order, carrying a minimum of clothes and provisions. We crossed the river, skirted the base of the Walsh Pyramid (Cbarroogin), traversed the twelve miles from there to Tringilburra Creek, crossed that creek and ascended Barnard's Spur to the top at 1,700 feet, and descended 700 feet to our camp by the Whelanian Pools. On the 13th we started up the mountain, and arrived on the summit at 5,000 feet in the afternoon, and decided to remain at our old camp for the night to give the boys the longest possible rest to qualify them for the work of the following day. At night the temperature was 42 degrees. Fortunately we had brought water from the Palm Camp at 4,000 feet, for the source of our previous supply had dried up, and there was no water anywhere on the summit. On the 14th we started for the unexplored peaks, drizzling showers falling, and the dense wet vegetation more unpleasant than the rain. About 9 o'clock we stood on the centre peak at 5,240 feet, nothing to be seen in any direction but drifting vapours, masses of white clouds, and general gloom, silence, and desolation. Another hour and we reached our previous farthest point, on the edge of a small precipice. And now began solid track cutting through vegetation simply infernal. The crest of the mountain was not anywhere more than 20 feet wide, at times narrowing to a crown of sharp rocks. The clouds were so dense that the view extended no more than 50 feet down each side, and we appeared as if travelling along a narrow dark track suspended in midair over bottomless vacuity. No words could picture that dreary dismal solitude. The only sound that broke the mournful stillness was the occasional rich noisy voice of Spalding's orthonyx - "Chowchilla" of the natives - or the peculiar call of my own bower bird, "Wargandilla." All else was but a

Sea of stagnant idleness,

Blind, boundless, mute, and motionless.

The temperature was 54 degrees; light rain continued all day, and the trees, shrubs, ferns, and palms dripped constantly in miserable monotony. The boys walked behind me in solemn silence, a melancholy procession, the soft sandshoes noiseless on the wet leaves and granite rocks, all too uncomfortable, or too much impressed by the desolate surroundings, to speak aloud to each other, even if all conversation had not been sternly forbidden.

About 2 o'clock the boys and Harold were some distance in the rear, and so cold that they stopped to light a fire to warm themselves, while Jimmy descended about 400 feet on the eastern side of the mountain, and brought back a billy full of. cold clear water from a running spring. I had left a mark on a tree at that spot to indicate the presence of water not far off, and Jimmy found my prophecy correct. On the top of a rocky peak, covered by the Dracophyllum and Bailey's Leptospermum wooroonooran, I waited for the boys to overtake me. This Leptospermum is the extraordinary dome-topped tree previously described, and which has realised my expectation that it would be found entirely new to botanical science.

About 5 o'clock tha deepening darkness compelled us to stop and arrange our camp for the night. We halted on a flat-sided slope close to the north peak, in groves of beautiful ferns growing among tall moss-covered trees, all strangers to me, but none of them fruiting 
or flowering. Remarkable everywhere on the summit are the numbers of trees with pleasantly and strongly scented woods. Some of these are peculiarly agreeable, and would, doubtless, distil excellent perfumes or highly odoriferous oils. At present Heaven only knows what valuable properties are lying latent and undiscovered among the vegetation of this mountain. There is now no excuse for allowing them to remain unknown much longer.

That night we stretched the light calico fly between two trees, closed the edge on three sides with ferns to keep out the cold wind, and made a fire in front. Our couch was made from the leares of ferns and palms growing all round us in magnificent luxuriance. Within thirty yards was a precipice at least 1,000 feet in depth. It is plainly seen from steamers passing along the coast, on the peak exactly opposite the Franklyn Islands. The boys made coffee and dined on a tin of Skinner's preserved meat. For my own supper I had a piece of stale bread and part of a grilled pheasant-tailed pigeon shot on the previous day. Nobody had any appetite worth mentioning after the day's work, and my right arm was nearly paralysed by seven hours' continuous track cutting with the cane-knife. We all slept fairly well, and as usual woke at daylight. When there was sufficient light I took Harold with me and started along the crest of the mountain to see if it was possible to take the boys on to the Nortl Peak, and thence home by Mount Sophia. The vegetation here displayed an abnormal rankness, clearly indicating nearly perpetual moisture. Suddenly, about a quarter of a mile beyond the camp, I came face to face with enormous granite rocks, where the mountain pinched in to nothing, with apparently bottomless precipices on both sides. Leaving the gun and cane-knife with Harold, I managed at considerable risk to travel about 200 yards beyond, and saw plainly that there was no chance of continuing in that direction, accompanied by the boys, unless we left everything we possessed, including the gun, blankets, and provisions. Returning to the camp, we prepared at once to go back the way we had come. I had traversed the whole Bellenden-Ker Range from north to south, and stood on every peak, including Mounts Toressa and Sophia, except the North Peak, at the foot of which I was now compelled to turn back. So far there was nowhere visible the track of any human being, black or white, on any part of the mountain, and certainly no mortal man would have passed along that summit anywhere without leaving tracks necessarily visible for many years. My path all along the crest of the range will be clearly visible to a bushman for ten to fifteen years. Our swags were reduced to a minimum. Two out of the three blankets were left in the fork of a tree, and each of us had only to carry about a dozen pounds. We started to return about 8 o'clock, and in five hours retraced the ten hours' journey of the day before, and reached the South Peak about 1 o'clock. After a cup of cocoa and a piece of dry bread, we started down the mountain, and in five hours more covered the whole journey to the Whelanian Pools. Harold and myself waited at the pools for half an hour until the boys arrived. My intention. was to camp there, but rain was threatening, and one wet night might bring down the creeks and shut us in effectually for an indefinite period. The boys came out of the scrub and down the rocks, and flung their swags on the bare granite with a soul-felt sigh of relief. It cost me a serere pang to ask them to go on to the top 
of Barnard's Spur, but I had treated them kindly and liberally all through the expedition, and they at once exclaimed, "All right, master," took up their swags and started after me as cheerfully as if going to a picnic. Ascending Barnard's Spur, it was nearly too dark to find the track. I pushed on to the summit, followed by Harold, and had a big fire ready when the boys arrived. They flung down their swags, crawled into one of the blacks' camps, and never moved until about 9 o'clock next morning. As for Harold, he seriously proposed that when the moon rose we should go on to the Mulgrare, a further day's journey of eighteen miles, after we had already done a two-days' severe journey in one day! This youngster's physical endurance is simply phenomenal. Next day we descended from Barnard's Spur, and arrived at the police camp on the Mulgrave about 4 o'clock in the afternoon. It would require very powerful reasons indeed to induce me to repeat the experience of those four days. On the 19th we all started for Cairns, and on the 21st went out to Kamerunga, and thence on the 22nd to the top of Freshwater Creek, where we were most hospitably entertained for a couple of days at the homestead of Mr. Andrew Banning. On the 26th we returned to Cairns, and next day left by the "Waroonga" for Brisbane, where we arrived on the 2nd of September, after a total absence of thirteen weeks, during which we had completed the whole of our programme, and a little more, leaving nothing undone that was contemplated except a trip with Mr. Bailey to the scrubs of the Upper Barron. We had made the most of our time; but that time was far too restricted to cover more than a fraction of the vast area available for exploration and botanical research. Still the results have far exceeded all anticipations, and though the flora and fauna of the summer months are ret untouched, the expedition may be safely regarded as a very satisfactory investment by the State, not only as a grand advertisement for the colony, but by reason of the splendid botanical results obtained by Mr. Bailey, in addition to the zoological, geographical, ethnological, and other information acquired during the period of exploration. The total cost, including the $£ 100$ paid for my official report, is less than $£ 400$, probably the cheapest scientific expedition on record. No one connected with the affair can be accused of reckless extravagance!

And now a few lines from the French of Pompignan, and a verse from Byron, slightly altered :-

\footnotetext{
Vanish, ye vast and gloomy views!

Ye rocks that pierce the warring clouds,

Of skies, enwrapped in misty shrouds,

Impracticable avenues.

Ye torrents that with might and main

Break pathways through the rocky walls

With your terrific waterfalls !
}

Farewell ! a word that must be, and bath beenA sound which makes us linger; yet-farewell! Ye who have traced the Pilgrims to the scene Which is their last, if in your memories dwell A thought which once was theirs, if on ye swell A single recollection, not in vain

They wore their sandshoes and their tights as well.

Farewell! with them alone may rest the pain,

If such there were-with you, the moral of their strain. 
VII.

THE FAUNA OF WOOROONOORAN.

In a preliminary passage to the report on the zoology of the Bellenden-Ker expedition, Mr. De Vis, the able Curator of the Queensland Museum, embodies the following observation:- "There is probably no part of Australia, certainly no part of Queensland, which at present excites the interest of the naturalist so forcibly as the district extending from Cardwell northwards for some distance beyond Cairns and inwards to the western slopes of the Razor-back Range. In this limited tract of coast country we find a concentration of forms of animal life elsewhere (in Australia) unknown. It has peculiar mammals, peculiar birds, peculiar reptiles, molluscs, insects, and in many cases these strangers to the rest of the land are derivatives, not from the surrounding Australian stock, but from the Indo-Malayan fauna on the one hand, and the Papaun on the other.

"The cause of the phenomenon is a problem of much interest in its bearing on the distribution of the lower animals, still more in its probably being an important factor in the history of man. But before attempting its explication, it is advisable that we should know as fully as possible the extent to which the peculiarities of this remarkable region are carried."

My two visits to the summit of Bellenden-Ker were during two entirely different seasons, and on each occasion there was a distinct flora and fauna.

Whelan, Barnard, and myself camped on the south peak on Sunday, the 3rd of February, and the scientific expedition arrived the same year at the same spot on the 22nd of June. The first ascent was in the heat of summer, the second in the coldest period of winter. The reptiles and insects of the 3rd of February were invisible on the 22nd of June, and the beautiful butterflies of the one period were totally absent in the other. So far as insects were concerned, we gave little or no attention, the season being entirely unsuitable. Among the shells collected are two which Mr. Hedley, of the museum, has declared to be new to science-one being a Nanina and the other a Helix. Referring to two new lizards, Mr. De Vis has the following observation:- " The discovery of two species of lacertian reptiles, both of them additional proofs of the statement previously made that an importation of extra Australian forms of life into this locality has, by some means, been brought about. These lizards can only be referred to the genera Perochirus (belonging to the Geckoes) and Tropidophorus (a genus of Scincs) found in Indo-China, Borneo, and the Philippine Islands, and not previously known to extend their range beyond those limits. Under the methodical names of Tropidophorus queenslandice and Perochirus mestoni these lizards have been described in the Proceedings of the Linnæan Society of New South Wales." These two lizards were discovered by me on the Barron River in the early part of last year and presented to the museum. Doubtless they would be found in summer time in country traversed by the expedition. Among the thirty-three different species of insects was a new Chilochorus, or ladybird, of remarkable peculiarities. The others may be passed over as known forms, though some are rare and interesting. Insects were of no account in our exploration. Principal of the mammalian specimens were two aboriginal skulls from defunct 
myalls of the Charroógin or Coolgibbera tribe of the Mulgrave River. One was the skull of a male, the other of a female. The intellectual development and cranial peculiarities will be found in the uncomplimentary description by Mr. De Vis, who informs us, with becoming scientific modesty, that both are "Dolichocephalic, mesognathous, microseme, platyrhine!" This will probably be considered sufficient for the average reader to meander along with in the meantime. They can purchase the balance in the official record and cut it up into 13-perch syllables, to be sold on the time-comprehensible s5stem. Among the rest of the mammals is the Yellow-shouldered Flying Fox (Pteropus scapulatus), a bat that extends to the islands in Torres Straits. Then comes the North Australian White-footed Rat (Acanthomys leucopis); followed by Hydromys leucogaster, or the Long-tailed Water Rat, common under different forms in many parts of Australia. There, too, is Halmaturus agilis, or the Red Creek Wallaby, found from Rockhampton northwards; a festive marsupial usually remarkable for his robust condition. Next to this light-hearted herbivorous gourmand is another Halmaturus, the skeleton only of which was found by me on the summit of the Little Mulgrave Range, and described by Mr. De Vis as "possibly an unknown species." Finally we have Dasyurus maculatus, or Spotted-tailed Native Cat, extending in various forms from Tasmania to the Cape York Peninsula. Two of these were caught in traps at 4,000 feet, and tracks were seen on the summit at over 5,000 feet. These cats are responsible for serious destruction of bird life.

In reviewing the birds of Bellenden-Ker the reader cannot reasonably expect me to do more than describe the most interesting of the seventy-nine distinct species among the 200 specimens collected by the expedition. Among the new birds named by De Vis is Ninox lurida, a small species of the Boobook Owl seen in dark scrubby gullies up to the Palm Camp at 4,000 feet. It is found on Bellenden-Ker and in the gorge of the Herbert River. Next is the Sericornis gutturalis, or Black-throated Sericorn, first shot by Mr. Broadbent, and found on Bellenden-Ker up to the highest peak at 5,240 feet. Most remarkable of all the birds named by De Vis is Prionodura newtoniana, or "Meston's Bower Bird." The name requires some explanation. On my first ascent of the mountain I shot a fullplumaged male specimen at 4, $\$ 00$ feet. This was regarded by De Vis as one of an entirely new species and named Corymbicola mestoni. Subsequently it appeared that a young uncoloured male had been previously shot by Broadbent on the head of the Tully, and received from $\mathrm{De} V$ is the name of Prionodura newtoniana. To me, therefore, belonged simply the honour of having shot the first full-plumaged male and observed the habits of this extraordinary bird, and the final name, to be known hereafter to science, is Prionodura newtoniana, or Meston's Bower Bird. Since the first male was found by me, sereral males and females have been shot by Broadbent on the Herberton Ranges at 3,500 feet. The blacks on the Mulgrave and hussell call this bird "Wargandilla." So far it is unknown south of the "Tully or north of the Barron. During the expedition we obtained seven wales in perfect plumage and several females. This is one of the three handsomest birds in Australia, the other two being the Riffe Bird and Regent Bird-Ptilorhis victoria and Sericulus melinus. In habits and peculiarities it is one of the most eccentric birds in the world. The. 
lowest descent was 1,500 feet, between the summit of Barnard's Spur and the Whelanian Pools. Usually it is found from 4,000 feet to 5,000 feet. The note of the female-a bird of common gray plumageis that of the ordinary green cat bird, in a sharper and shriller key. The male appears to possess the marvellous imitative powers of the Australian lyre bird. First you hear him croaking like a tree frog, and this note is followed by a low, soft, musical, pathetic whistle, succeeded in a rapid succession by an astonishing imitation of apparently all the birds in the scrub. The bower varies in size and shape, but in all cases differs from that of the other Australian bower birds. Both Broadbent and myself have seen bowers up to a height of 8 feet. As a rule they are made between two small trees about 4 feet or 5 feet apart. Short dead sticks and twigs are piled up against each tree in a gently contracting pyramid, and across from base to base extends an arch-shaped causeway, occasionally spanned by a connecting vine decorated with green mosses and tufts of tiny ferns. In and out and over and under and around this erratic structure both male and female birds disport themselves in frequent playful festivities, like the lyre bird, regent bird, and satin and other bower birds remarkable for similar customs and proclivities. So far only one nest has been discovered-the one found by me on the summit of the Little Mulgrave Range. It was a round cup-shaped nest, decorated outwardly with the mosses and ferns used in ornamenting the bowers. It contained only one egg, quite fresh; so we have yet to learn if the bird lays one or more. Another specially interesting bird is Orthonyx spaldingi, or "Spalding's Orthonyx," named after Spalding, of the museum, one of the best taxidermists in Australia. This bird is peculiar to the district, and on Wooroonooran we found it from the base to the summit at 5,240 feet. It runs about on the ground in dense scrub and scratches among the leaves like the Coachwhip Bird (Psophodes crepitans), to which it bears a certain rescmblance, though double the size and weight. Remarkable in this bird is the abnormal thickness and strength of the thighs. It has great imitative powers and a rich full gurgling voice of great compass, and apparently inexhaustible capacity. It is the noisest bird in the scrubs. The blacks call it "Chowchilla," probably "jowa-chilla," from "jowa" the mouth and "chilla" to gabble. The Pied Crow Shrike (Strepera graculina) they call " jowajowa," literally " all mouth," from the stonewalling proclivities of this noisy bird. The lovely Blue Wren (Maluris amabilis) we found at 2,000 feet, and the handsome fawncoloured Nankeen Heron (Nycticorax caledonicus) was shot near the Palm Camp at 4,000 feet. On my first ascent of the mountain, in February, there were considerable numbers of the White-headed and Pheasant-tailed Pigeons (Carpophaga norfolciensis and Macropyqia phasianella) from 4,000 feet to 5,000 feet. These birds were breeding, and had their nests in the top of tree-ferns, 6 feet or 8 feet above the ground. Each nest contained a single egg or solitary young pigeon; poor, soft, woolly little mites, crouching in helpless innocence in the open nests, dependent solely on their parents for protection against storms and rain. Both species were in grand condition, having a rare fattening ground among the berry-bearing trees of the summer months. The Common Jackass (Dacelo gigas) was seen up to 2,700 feet. Nests of the Scrub Turkey were seen at 4,500 feet, but the Scrub Hen (Megapodius tumulus), one of the mound builders, was not heard or seen 
above 2,600 feet. The nests on the mountain were much smaller than those on the level country, by reason of the difficulty of collecting dead leaves and twigs. In the scrubs of the Barron there are megapode nests over 6 feet high and 80 or 90 feet in circumference at the base, the accumulation of many years. In my garden at Cambanora there are five large orange trees growing luxuriantly on one of these extraordinary mounds. The ground is scraped clean for a distance of twenty or thirty yards round the nests, the birds walking backwards and throwing the dead leaves behind them in successive stages of 4 feet to 5 feet. The Scrub Hen can be heard cackling at all hours of the night. She lays her eggs very early in the morning, and three or four hens utilise different parts of an old-established nest. Each hen lays from six to twelve eggs, as large as that of a tame turkey, and of a light drab or brown colour on the outside, which can be easily rubbed off, leaving the egg as white as a hen's. The Spotted Cat Bird we found up to 4,000 feet, and the Toothbill Cat Bird, peculiar to the district, was never seen lower than 2,500 feet. The Dragoon Bird (Pitta strepitans) we found plentiful in the Mulgrave and Russell scrubs. The blacks call it "Derrim-derrim," and "Tikoóya." It lives chiefly on snails, and can be heard frequently braeking the shells on a stone. No other bird decomposes so rapidly after death. It will not keep fresh over two hours on a hot day. This is attributable chiefly to the snail diet.

The Cassowary (Casuarius australis) is common in the scrubs of the Mulgrave and Russell, and occasionally they ascend the mountain spurs to over 2,000 feet. A large cassowary stands over 6 feet and weighs up to $200 \mathrm{lb}$. We obtained five specimens, the largest weighing $186 \mathrm{lb}$. A full-sized egg is 6 inches in length, 12 inches round the "equator," and 16 inches round the "poles," of a bright green colour, much more attractive than the egg of the emu. There is no attempt at a nest, the hen laying anywhere in the scrub in a sheltered spot, usually among very dense vegetation. She lays from three to six eggs, and sits on them apparently about a month. When a day or two old the young run at a surprising pace, and if pursued will vanish in holes or hollow logs, or under leaves or ferns, with astonishing celerity. Usually they are in charge of the male bird. Externally there is no difference whatever in the appearance of male and female. The largest birds I have shot were all females. Both have the wattles on the neck, but one very large female, shot by me on the Barron and now set up in the Museum, had no trace of wattles; the first known specimen destitute of that adornment. A special chapter is required to properly describe the habits and appearance of this magnificent bird. Among the parrot species found on the mountain were Pennant's Parrakeet, the King Lory, Blue Mountain, Macleay's, and Scalybreasted Lorrikeets. The pigeons included Swainson's Fruit Pigeon, the 'l'opknot Flock Pigeon, Magnificent F'ruit Pigeon, White-headed Pigeon, Long-bill Green Pigeon, Pheasant-tail Pigeon, and the Nutmeg or Torres Straits Pigeon (from October to April). The Wonga is unknown in the district. Among the cockatoos were the common White Sulphur-crested Cockatoo, Bank's Black Cockatoo, and the Great-billed Black Cockatoo, all three plentiful on Barnard's Spur up to 1,700 feet. The beautiful Bee-eater (Merops ornatus) was seen up to 4,000 feet. This is the only bee-eater in Australia. The Black Crow Shrike (Cracticus quoyi) was shot at 3,000 feet. This bird is found in the Cape York Peninsula and New Guinea. We also shot 
the Crescent-marked Oriole, a bird peculiar to the district and New Guinea. On the Mulgrave Plains we shot the Plain Turkey and the Stone Plover, usually known as the "Gray Forest Curlew." We also got the Spur-winged Plover, the Gray Duck, Pigmy Goose, Red Teal, Whistling Duck, Scrub Rail, Swamp Rail, Brown Quail, Spoonbill, and Straw-necked Ibis. Our capacious soup-pan, which held 5 gallons, usually contained scrub turkeys, scrub hens, pigeons, parrots, cockatoos, and any other bird except the crow, the heron, and the jackass. All else were boiled down promiscuously into a nutritious and savoury extract, flavoured according to Soyerian rules, and distributed in pannikins to the assembled guests, who generally eat on the principle of the man who said he was naturally a very small eater, but found that a large meal agreed best with his constitution.

Among the rest of the birds were Wrens, Robins, Shrikes, Honeyeaters, Thrushes, Kingfishers, Flycatchers, Swifts, Swallows, Owls, Hawks, Falcons, and sundry others, all too numerous to have more than their names recorded in this article. The best months for the collector of birds, insects, reptiles, butterflies, and animals are December, January, and February; but he would risk the wet season, and no man would care to live in the scrubs of Bellenden-Ker after the advent of the tropical rains.

\section{VIII.}

THE FLORA OF WOOROONOORAN.

This is a chapter containing a very brief description of the specially interesting section of the Bellenden-Ker flora, and intended for the ordinary reader who either dreads or has no desire for a personal orthographical struggle with Mr. Bailey's official report; a struggle in which the reckless gladiator would probably be paralysed in the second or third round, even if fully armed with the largest time-payment family dictionary and Greek and Latin lexicon. The necessity for brevity is seen when the reader learns that on and around that one mountain we found considerably over six hundred different species of plants fruiting or flowering in the coldest months of the year, exclusive of the mosses and lichens, which are not yet classified.

In his report Mr. Bailey says :- "The results of the expedition, from a botanical point of view, have proved highly satisfactory; about thirty fresh plants have been added to the known flora of A ustralia, equalling in number those added to the flora of New Guinea by Sir William Macgregor's late expedition to the Owen Stanley Range, which is 8,000 feet higher than Bellenden-Ker, and proportionately extensive in area. It being winter, a large number of the trees and shrubs were without flower or fruit, consequently could not be identified."

In a few notes on the plants collected by D'Albertis in New Guinea, I find that Dr. O. Beccari regards the flora of that island distinctly Malayan, as he found only one Eucalyptus, two Banksias, and one Acacia that could be regarded as true Australian trees. But he had only a rudimentary knowledge of the affinity between the Australian and New Guinea floras and was not in a position to either weaken or strengthen the belief of D'Albertis himself, that in a former age the two island continents were joined together and will be united again in the remote future. 
The botanical researches of Mr. Bailey and Baron von Mueller will supply valuable information towards elucidating the interesting question of ancient relationship between Australia and the vast mysterious and fascinating island lying within 100 miles of where our North Cape stands, grim and silent, behind its rampart of rugged rocks broad based in the sea-green surges of the Coral Ocean.

The flora and fauna of the Cape York Peninsula, especially north from Princess Charlotte Bay, are comparatively unknown; and we have yet to learn if anywhere between Bellenden-Ker and Cape York there exist any distinctive animal or vegetable links closely associating us with our mighty neighbour. There is now no longer a doubt that Wooroonooran possesses a flora peculiarly its own. Among Mr. Bailey's new species are some not likely to be found anywhere else. The whole range is clothed in dense tropical jungle from base to summit, there not being a single open space fifty feet square, except a batch of ferns on the south spur at 2,700 feet, and a few hundred yards of forest on the west spurs of Mounts Sophia and Toressa. Among the specimens collected were 110 different species of ferns and twenty-six different orchids. We found thirty-eight species of edible fruits, some of them very mutritious and of very agreeable flavours. The choisest of them will yet be cultivated and run a close competition for popularity with the best of our civilised fruits. Among them is the Citrus inodorous, or Scentless Lemon, named by Bailey, a tree with rich, dark-green foliage, bearing a fruit the size of a small lemon, with a sharp, agreeable, acid taste, and very refreshing. We also found Acronychia acidula, or Scortechini's Crab, a form of which is found on the Logan, where attention was called to its usefulness by the late Rev. Father Scortechini. Among the smaller fruits were five species of native grapes belonging to the order Vitis, the wild tamarind, two quandongs, called "Curroógi" by the blacks; the Burdekin Plum, "Bomban" and "Rancooran" of the natives; fire species of edible beans, six nuts, three cherries, one blackberry, one raspberry, one loquat, four figs, one geebung, and one nutmeg. None of the large fruits were available except the mangosteen, as the superb specimens seen on my first ascent in February belong to the summer months. We found the Herbert River Cherry (Antidesma Dallachyanum) heavily laden with ripe fruit, which is pleasant to eat in the raw state, and can be turned into excellent jam or jelly. There also in great abundance was Davidsonia pruriens, or Davidson's Plum, a blue-black plum the size of a duck egg, the interior a rich bright-purple juicy pulp, a sharp acid, very pleasant flavour, a remarkably refreshing fruit, with the happiest effect in assisting digestion. It is a great favourite of the cassowary, who marches round daily to pick up the fallen fruit.

Principal of the nuts is the Cóa, a round, clean nut as big as the largest walnut, growing on a tree which attains an immense size. This nut is often confounded with the Coí, a small red fruit growing on a climber, and eaten by the blacks after cooking on hot stones. In the first the accent is on the " 0, " and in the second on the " $\mathrm{i}$. ." The Cóa is eaten raw, and is a palatable and nutritious fruit. The natives regard it with special favour. The loquat, known as the Cooktown Loquat (Rhodomyrtus macrocarpa), is an edible red juicy fruit, eaten with gusto by all the frugivorous birds. One of the Eugenias (E. cormiflora) bears all along the trunk a large pink and white fruit, called "Murroo" by the blacks, who eat it occasionally, though rather 
spongy and insipid. Another Eugenia (E. oleosa) bears a lovely bright-blue fruit, that would have a charming effect in the decorating of a banquet hall, or ballroom or evening party. The Helicia Whelani, named by Bailey after Sergeant Whelan, bears a large nut, extensively used for food by the blacks, in whose camp we found the shells or whole nuts in considerable quantities. It is roasted and eaten without any maceration in water, apparently containing no poisonous principle. Chief of all the fruits is the Garcinic Mestoni, or Meston's Mangosteen, already described in a previous article. Mr. Soutter, of the Acclimatisation Gardens, is now trying to germinate the seeds of this and two other large fruits, at present unnamed, as only the seeds were found on the recent expedition. The true nutmeg grows everywhere in abundance, and forms the favourite food of the Straits pigeons when down for the breeding season. It is smaller than the nutmeg of commerce, but exactly the same in all other respects. Botanically the name is Myristica insipida.

Referring to my mangosteen, I find that among the plants collected by D'Albertis on the Fly River in 1877 there is only one Garcinia, named G. subtilinervis by Von Mueller, and also only one Chavica of the Piperaceæ or Long Pepper family. Our expedition also discovered only one Garcinia and one Piper, both named after myself. [Gradually I am being seized by a fearful suspicion that Science is sending me careering down to posterity like a human comet launched through the astral universe of immortality, with such an appalling and apparently interminable tail of luminous scientific appendages, that my descendants will one day, while smarting under a keen sense of unendurable orthographical outrage, rush round to the Registrar-General with a legally compiled document intimating that from thenceforth and for ever they have altered their name to "Jones."]

About twent5 years ago a writer in one of the English magazines gravely informed the inhabitants of this planet "that in Australia there are no edible wild fruits, no flowers with perfume, or birds with song." Probably no other human ass ever compressed a larger and more varied assortment of reckless ignorance into a smaller amount of space. Yet the gospel according to that literary cuddy is still accepted by the section of the old country inhabitants whose opinions on Australia are about as lucid and valuable as a native bear's theory concerning religion in State schools.

All over Australia are palatable wild fruits, many pleasantly scented flowers, and birds that sing or whistle as sweetly as any in the world, the nightingale alone excepted.

Nearly all of the flowers of the tropic north are perfumed, some of them diffusing a delightful odour. The Dracophyllum of Wooroonooran bears one of the most magnificent flowers in the world. Some of the orchids bear deliciously fragrant flowers, and on the summit of the mountain is a handsome shrub bearing a small white flower with a fascinating scent, such as I never met with before. The specimens of this were lost.

Among the perfume-bearing plants is the Orites fragrans, named by Bailey, who describes it as "a most attractive plant from the rich colour and fragrance of the inflorescence." The same sentence applies exactly to one of the Hollandras found on the mountain, according to Bailey, "a most desirable tree for garden culture." One very handsome tree is named Cyanocarpus Nortoniana, after the Hon. A. Norton. 
The peculiar dome-topped tree, so often referred to in previous articles, is named Leptospermum wooroonooran. Strange indeed if this extraordinary tree is found nowhere in this world except on the top of that mountain, the sole survivor of an ancient race, standing there in gloomy isolation contemplating the surrounding Solitudes, rescued, uninjured, like Cato's soul, from out the "war of Elements, the wreck of Matter, and the crush of Worlds." From the crest of Bartle Frere comes Melicope chooreechillum, a small tree bearing a thick white flower. The Queensland Climbing Bamboo, named Bambusa Moreheadiana, after the present Premier, is a most imposing plant, ascending to the tops of the tallest trees, crossing over to others, and hanging in splendid festoons of leaves ten inches long and two inches wide from the overarching spaces. It is found in the densest and richest scrub. Some idea of the size of this splendid plant can be found in the fact that it attains a length of over 200 feet. Among the large trees of that district is the Ficus colossea, or Colossal Fig, a tall, handsome tree, with straight, smooth, bright-green trunk. From the enormous flanges of this tree, called "Maccorah," the blacks cut their shields, "Beekan," and when dry it is tough and light, and stands a surprising amount of wear and tear. This is a favourite tree for the nests of the Calornis metallica, or Bright Metallic Starlings, which build like the Baltimore Oriole, and hundreds of these huge nests on one tree give it the appearance of having stopped a haystack flying round in a cyclone.

Ruthless warfare will yet have to be waged against this fruitdestroying bird, which comes there like the Straits pigeons, annually to breed, and then goes north to Cape York and New Guinea. On all the creeks up to 1,200 feet we saw the Umbrella tree, Brassaia actinophylla, in magnificent perfection, with rich crimson flower spikes four feet in length. I find this Northern tree in many private gardens in Brisbane, where it will never attain the luxuriance and splendour of the tropics.

Among foreign plants were the Trema orientalis, or gunpowder charcoal tree; the Urena lobata, or flax fibre plant; the Lasmani, the Madras Hemp Plant, and the Kirrari and Kierpa trees, all of India. Also the A siatic Pennywort, the "Dabur" of Bengal, the "Pavetti" and wild Taro, and "Ponga" tree of India, the Java Filmy Fern, and several other strangers found for the first time in Australia. Among the 110 different ferns are some stately and splendid specimens, and others small and delicately beautiful. Imagine a fernery containing all these varieties! Of the tree ferns, one of the handsomest has been named by Mueller after some damsel or matron called "Rebecca." He might as well have called it "Jemima" or "Alsophila Mary Ann," so far as the distinguishing nature of the terminal is concerned. Hundreds of this glorious fern were destroyed in cutting our tracks. The summit of Wooroonooran is the sole Australian habitat of the White-leaved Bristle Fern, found here for the first time. At 4,000 feet we got the Wig Fern Tree, hitherto found only in South Africa, Brazil, and Java. There also is the Iovely Hairy Fern, known previously only by a single frond obtained on the east side of Mount Toressa by Walter Hill in 1873 . We saw tree ferns over 40 feet in height, said by Mr. Bailey to represent a great age. The Rebecca fern is the one chosen for nesting in by the white-headed and pheasant-tail pigeons, in January and February. Among the new orchids were Oberonia 
pusilla and Bulbophyllum Toressa, the latter named after my first-born, one found at 4,000 feet and the other at the Whelanian Pools, both flowering in June and July. Many of the orchids were in flower, beautiful blossoms diffusing a rare fragrance, conspicuous among them being Dendrobium speciosum, summit of Charoogin, and Bailey's orchid, which was flowering in splendid perfection at the Morehead Cataracts and Francesca Falls. The orchids and ferns seen in our gardens and summerhouses bear the same resemblance to their wild free brethren of the hot moist tropic jungles that a caged eagle with half his tail gone, a foreclosed mortgage on his feathers, and a bilious headache bears to the noble bird sweeping through the sunlit fields of air in all the glory and perfection of unfettered freedom. The Queen street myall, wearing a brass medallion resernbling a doctor's doorplate, and in his uncertain eje the melancholy and hopeless expression contracted by persistently gazing far away down the dim and shadowy vista of empty bottles, differs not more widely from the wild son of the forest whose foot treads proudly on his native heath, whose beverage is spring water, and the monotony of whose vegetarian diet is occasionally varied by choice fillet of barbecued Chinaman. Among the plants becoming naturalised and growing wild in that district are the pa-paw apple, granadilla, apple guava, red pepper, citron, passion fruit, tomato, tobacco, castor oil, and many grasses. Among the fibrous plants is one called "Boorgay" by the blacks, a ground plant with radiating long narrow leaves extending to three feet in length. The leaves are about two inches wide tapering to a point; one of them would suspend $100 \mathrm{lb}$. The blacks use the leaves as rope, twist a couple into a band, and carry surprising loads, the weight all bearing on the band passed round the forehead; of course only the skull of a myall or an alderman will submit to such a formidable strain. The botanical name is Gymnostachys anceps, a title about as tough as the plant. It was found on Chooreechillum up to 4,000 feet. Among the large trees were stavewood, red beech, red and white cedar, tulip, ivorywood, bean-tree, red sandalwood, blue and grey gums, bloodwood, Moreton Bay ash, box, Leichhardt, beefwood, swamp and forest oaks, stringy-bark pine, dammara, and kauri and she-pines, and many giant trees not yet known or described, the local names of which are only misleading to the inquirer.

We found several plants known in other countries to possess more or less valuable medicinal properties, one of them being the Indian wild Taro, the tubers of which are used as a potent fomentation in rheumatism. Among the canes were the Midgen, and the large and small lawyer canes, called "Yaplam" by the blacks. There were some magnificent palins, two of them with leaves from 10 feet to 20 feet in length. We got over thirty specimens of grasses, some exotic and some indigenous.

This is but a meagre outline of the vast assortment of specimens obtained by the expedition, and a rich and extensive field yet remains for further botanical exploration.

Erratum.-The two Herberton lakes are "Yeetcham" and "Barrang": the name "Boonoobagolamee" being given by the natives to the third lake, at present unknown to white men.

By Authority : Jandes C. BEAL, Government Printer, William street, Brisbane. 







$$
\text { • }
$$


